\title{
Cesário Verde e o desconcerto do eu.
}

Dissertação apresentada na Faculdade de Filosofia e Ciências Humanas da Universidade de São Paulo para obtenção do título de

Mestre em Literatura Portuguesa

Área de concentração: Literatura Portuguesa Orientador: Prof ${ }^{\circ}$ Dr. Álvaro Cardoso Gomes

São Paulo

2008

v.1 


\section{RESUMO}

OZAWA, André Yuiti. Cesário Verde e o desconcerto do Eu. 2008. 110 f. Tese (Mestrado) - Faculdade de Filosofia, Letras e Ciências Humanas, Universidade de São Paulo, São Paulo, 2008.

O objetivo principal desta dissertação foi analisar, sob uma ótica intimista, o corpus poético do poeta português Joaquim José Cesário Verde(1855-1886). A idéia da escrita de si, da constituição do sujeito através da palavra escrita, remonta desde gregos e egípcios, ganhando força no final de Idade Média através das memórias, dos diários e dos livre de raison, e explodindo definitivamente enquanto gênero com as autobiografias. Analisando como o $e u$ se constitui dentro do poema, e, conseqüentemente, as crises de consciência e do mundo, é possível observar como este mesmo eu caminha para um desconcerto, para a última e definitiva crise, que é o abandono da arte como forma de se conciliar consigo e com o mundo.

Palavra-chave: Cesário Verde, desconcerto, escrita de si, poesia, crise de consciência. 


\begin{abstract}
OZAWA, André Yuiti. Cesário Verde and the confusion of the self. 2008. $110 \mathrm{f}$. Theory (Master's degree) - Faculdade de Filosofia, Letras e Ciências Humanas da Universidade de São Paulo, 2008.

The principal objective of this dissertation analyzed, under an intimism optics, the poetic corpus of the Portuguese poet Joaquim José Cesário Verde (1855-1886). The idea of the writing of the self, of the constitution of the subject through the written word, remounts from Greeks and Egyptians, gaining strength in the end of Middle Ages through the memories, the diaries and of release of raison, and exploding definitely while type with the autobiographies. Analyzing as I it is constituted inside the poem, and, consequently, the crises of conscience and of the world, it is possible to notice how this one himself. I walks for a confusion, for the last and definite crisis, which is the desertion of the art like the form of being reconciled by you and by the world.
\end{abstract}

key word: Cesário Verde, confusion, writing of the self, poetry, crisis of conscience. 
Dedicatória

Dedico este trabalho à minha família e a Amaísa Iglesias, com amor. 


\section{Agradecimentos}

À Professora Doutora Eliane Alcântara Teixeira, por ser a primeira a acreditar, academicamente, neste aluno.

Ao Professor Doutor Álvaro Cardoso Gomes, por abrir as portar deste mundo acadêmico e pelas valiosas contribuições.

Á Professora Doutora Raquel de Souza Ribeiro, pelo constante e irrestrito apoio intelectual na confecção deste trabalho.

Á Professora Doutora Annie Gisele Fernandes, paradigma de mestra, por ter contribuído desde o primeiro até o último dia, na formação deste aluno.

Aos Professores José Eduardo Ferreira e José Renato Toledo Barboza, pelas constantes e intermináveis discussões filosóficas. 


\section{SUMÁRIO}

INTRODUÇÃO

DO RISÍVEL AMOR DE SI AO DESASTRE DO OUTRO...21

DO AMOR AO OUTRO AO DESASTRE DE SI....................68

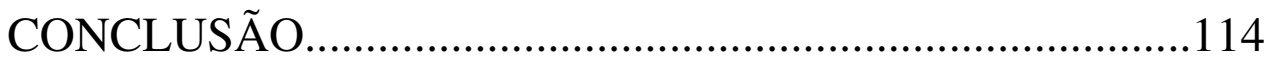

REFERÊNCIAS BIBLIOGRÁFICAS....................................119 
Quem pode ser no mundo tão quieto, Ou quem terá tão livre o pensamento, Quem tão experimentado e tão discreto, Tão fora, enfim, de humano entendimento Que, ou com público efeito ou com secreto, Lhe não revolva e espante o sentimento, Deixando-lhe o juízo quase incerto, Ver e notar do mundo o desconcerto. (Luís Vaz de Camões) 


\section{Introdução}

A obra poética de José Joaquim Cesário Verde, nascido em 25 de Fevereiro de 1855, na freguesia lisboeta de Madalena, e falecido, aos 31 anos, em 19 de julho de 1886, nos chamou a atenção, primeiramente, pela diversidade estilística que o autor impôs aos seus versos. Alguns livros didáticos revezam-se, muitas vezes a fórceps, em tentar enquadrá-lo dentro de algum período, escola ou estética literária. A discussão desta dissertação, porém não intenta "corrigir" nem buscar elementos que comprovem ser esta ou aquela linha estética que o autor buscou. A intenção primeira é analisar o corpus poético de Cesário através da perspectiva intimista, que se define "sobretudo pela busca de sentido do sujeito, que nos leva a atentar para as questões do intimismo, da auto-representação, do auto-conhecimento e da importância das operações da memória nesse processo."1

O corpus escolhido foi quase o todo: não se quer com isso intencionar abranger a totalidade de sentidos possíveis da poesia cesárica, nem encontrar uma chave explicativa para o entendimento de todas as poesias. Através de um quase close reading (na falta de um termo mais específico), os poemas são analisados numa ordem supostamente cronológica, primeiramente como entes individuais, e posteriormente, complementando a explicação da analise intimista. O método utilizado pode ser definido como o da hermenêutica que busca no próprio texto a explicação para si. Com isso, possíveis interpretações extraliterárias são deixadas à margem, não por serem elas desnecessárias ou errôneas, mas para ressaltar o que o texto tem de valor dentro de si e permitir que a interpretação seja feita estritamente dentro da linha aqui proposta.

\footnotetext{
${ }^{1}$ FERNANDES, Annie Gisele. Espaços do ser e do não-ser e a construção do sujeito em Mário de Sá-Carneiro. In: FERNANDES, Annie Gisele; OLIVEIRA, Paulo Motta. Literatura Portuguesa: Aquém-Mar. Campinas: Editora Komedi, 2005, p. 184.
} 
Mas o que valida a opção por esta e não outra abordagem? Se, no começo já foi dito o que primeiramente chamou a atenção na obra de Cesário, a explicação do que posteriormente manteve tal atenção viva foi como Cesário "constrói” um eu-lírico e ao mesmo tempo o "desconstrói", ao condicionar a existência deste $\mathrm{Eu}$ as sensações causadas pelo meio, e inversamente, condicionar a apreensão deste meio pelas sensações próprias deste Eu, num jogo objetivo versus subjetivo, Eu e Outro, solidariedade versus individualidade. Assim, é este Eu que se impõe no meio do processo de confecção do poema a encruzilhada de certa maneira também entre a história que se conta e o que conta de si. "Na designação genérica, o termo intimismo é empregado para distinguir a vida privada da vida pública; a vida íntima, familiar, da vida social. Num sentido mais técnico, o intimismo apresenta-se como a definição do privado que pode ser observado através do psicologismo ou através da representação do íntimo."

As memórias, os diários, os livres de raison ${ }^{3}$, são exemplos em que a forma mais genérica deste intimismo prevalece, e são as expressões essenciais da escritura privada do final do século XVII e durante o XVIII:

Não é fácil penetrar na vida privada nem na vida íntima situado no interior da vida cotidiana, ou porque se confundem com a vida pública, ou porque, ao contrário, se escondem atrás do próprio pudor em revelá-las. Pesquisá-las em memórias, diários e livres de raison visa não a construir, a partir de incidentes e fatos curiosos, uma vida privada contida no relato - muitas vezes brilhante - de numerosas vidas cotidianas, e sim entender como as mentalidades a perceberam: portanto, menos a vida privada que a atitude ante a vida privada, e não só a narrativa, mas também os silêncios: não só o discurso, mas igualmente sua aridez ou até a sua ausência. ${ }^{4}$

\footnotetext{
${ }^{2}$ Ibidem, p. 183.

3 "Para defini-los podemos recorrer ao insubstituível Dictionnaire (1690) de Furetière: 'Memórias, no plural, diz-se dos livros dos historiadores escritos por aqueles que participaram dos fatos escritos por aqueles que participaram dos fatos ou foram suas testemunhas oculares ou que contêm sua vida e suas principais ações. Corresponde ao que os latinos chamam 'comentários'(...).Livre de raison é um livro no qual um bom chefe de família ou um comerciante anota tudo o que recebe e gasta a fim de manter um controle sobre todos os seus negócios." FOISIL, Madeleine. A Escritura do Foro Privado. Trad. Hildegard Feist. In: ARIÉS, Philippe; DUBY, Georges (Org.). História da Vida Privada 3: Da Renascença ao Século das Luzes. 13. ed. São Paulo: Companhia das Letras, 1990.Título Original: Histoire de la vie privée, vol 3: De la Renaissance aux Lumières, p. 331 e 332.

${ }^{4}$ Ibidem, p. 331.
} 
A importância de se notar que, o que se busca na escrita intimista - ou como a chama Foisil: foro privado - não é reconstituir a vida do escritor, e sim como este escritor percebe a vida é basilar para a explicação do porquê elementos extraliterários, notadamente os biográficos, são deliberadamente deixados de lado para a explicação da constituição deste Eu.

Como diz Octávio Paz, ao escrever sobre Fernando Pessoa: "Os poetas não tem biografia. Sua obra é sua biografia. Pessoa que duvidou sempre da realidade deste mundo, aprovaria sem vacilar que fossemos diretamente a seus poemas, esquecendo os incidentes e os acidentes de sua existência terrestre."

Tratando sobre o mesmo assunto que Madeleine Foisil, sob uma perspectiva contemporânea, Marcello Duarte Mathias tem conclusão parecida: mesmo quando as memórias têm intenção autobiográfica, ali não mais se encontra o autor, e sim, no máximo um pacto autobiográfico:

O gênero memorialístico inclui fundamentalmente as memórias, as autobiografias, certas correspondências e os diários, porque em todas estas expressões a memória representa o elemento primacial que lhes serve de traço comum. Partilham também do facto de se centrarem na pessoa do autor, privilegiando o olhar individual, pois é dele, e da sua singularidade, que decorre todo o resto. Vocação que é assim, ao mesmo tempo, refúgio e afirmação pessoal. Por isso, qualquer distinção, independente do critério adoptado, será sempre marginal, já que não põe em causa a essência daquilo que as define, a saber, a coincidência entre autor, narrador e personagem: o que se designa por pacto autobiográfico. ${ }^{6}$

O mesmo autor notará que a autobiografia é o "relato de uma vida pelo próprio, sendo o autor simultaneamente o destinatário e o personagem-objeto da narração", , e que, o critério de unidade é, afinal, o cronológico, numa tentativa inócua de reconhecer-se como um todo; "Rembrandt, ao pintar cerca de uma centena de auto-retratos, compõe também, fascinado que estava pelo seu visível envelhecimento, os vários capítulos de sua jamais terminada

\footnotetext{
${ }^{5}$ PAZ, Octavio. O Desconhecido de si mesmo - Fernando Pessoa. Trad. Sebastião Uchoa Leite. In: Signos em Rotações. 3. ed. São Paulo: Editora Perspectiva, 2003, p. 201.

${ }^{6}$ MATHIAS, Marcello Duarte. Autobiografias e Diários. In: Colóquios/Letras. Janeiro-Junho 1997, número 143/144, p. 41.

${ }^{7}$ Ibidem, loc. cit.
} 
autobiografia. Porque se em todos está presente, em nenhum afinal se reconhece." ${ }^{8}$ A idéia é que o pincel imobiliza um momento fugaz de um mundo fragmentado, em constante mudança, e cujo enigma está muito aquém e além dele.

Esta separação distinta entre obra e autor, entre o Eu do poema e o Eu que tem um nome, que por ventura coincide com o do autor, é importante para o entendimento da linha de pesquisa aqui executada. Quando escreve sobre si, a escrita constitui um “corpo":

"E este corpo, há que entendê-lo não como um corpo de doutrina, mas sim de acordo com a metáfora tantas vezes evocada da digestão - como o próprio corpo daquele que, ao transcrever as suas leituras, se apossou delas e fez sua a respectiva verdade: a escrita transforma a coisa vista ou ouvida "em forças e sangue". Ela transforma-se, no próprio escritor, num princípio de ação racional. " 9

Apesar de mencionado anteriormente que a escrita deste espaço privado começa a tornar-se uma espécie de gênero nos séculos XVII e XVII, "muito provavelmente favorecida pela nova relação que se estabeleceu com a escrita, quer pelo progresso da alfabetização e da circulação da palavra escrita, impressa, quer pela difusão da leitura silenciosa e pelo fortalecimento da relação íntima, reservada e solitária, entre indíviduo e livro", 10 gregos e latinos tinham mecanismos de reflexão ou análise do eu. Os hypomnemata eram usados como uma espécie de caderno pessoal, que serviam tanto para registros mais práticos, como os contábeis, quanto como uma espécie de livro de vida, guia de conduta, pois neles se registravam citações, fragmentos de obras, "exemplos e ações de que se tinha sido testemunha ou cujo relato tenha lido, reflexões ou debates que tinha ouvido ou que tivessem vindo à memória." ${ }^{11}$ Foucalt também chama a atenção para o papel da constituição de si que os hypomnemata adquire, pois, menos do que um simples auxiliar da memória, que poderia ser recorrido por ventura, eram utilizados como instrumentos freqüentes de leitura, releitura e reflexão, e tem um uso ativo: "Para isso é preciso que eles não sejam simplesmente arrumados como num armário de recordações, mas profundamente implantados na alma, 'gravados nela',

\footnotetext{
${ }^{8}$ Ibidem, loc. cit.

${ }^{9}$ FOUCAULT, Michel. O que é um autor?. Trad. António Fernando Cascais e Eduardo Cordeiro. 6. ed. Lisboa: Nova Vega, 2006. Título Original: Qu'est-ce qu'un auteur? p. 143.

${ }^{10}$ FERNANDES, Annie Gisele, op. cit, p. 184.

${ }^{11}$ FOUCAULT, Michel, op. cit., p.135.
} 
diz Sêneca, e que desse modo façam parte de nós próprios: em suma, que a alma os faça não apenas seus, mas si própria."12

Os hypomnemata, no entanto, não se constituem ainda na escrita de si propriamente dita. Não é uma narrativa de si, mas uma espécie de indícios de como o externo ao subjetivo, à alma (como diz Sêneca), molda este espírito que se encontra consigo mesmo, olhando primeiramente para fora, e posteriormente, quando esses elementos externos, tradicionais já o são familiares, já foram capturados, olhando, de forma invertida, para si mesmo:

Por mais pessoais que sejam, estes hypomnemata não devem porém ser entendidos como diários íntimos, ou como aqueles relatos de experiências espirituais (tentações, lutas, fracassos e vitórias) que poderão ser encontrados na literatura cristã ulterior. Não constituem uma 'narrativa de si mesmo'; não têm por objectivo trazer à luz do dia as arcana conscientie cuja confissão - oral ou escrita - possui valor de purificação. O movimento que visam efectuar trata-se, não de perseguir o indizível, não de revelar o que está oculto, mas, pelo contrário, de captar o já dito; reunir aquilo que se pôde ouvir ou ler, e isto com uma finalidade que não é nada menos que a constituição de si. $^{13}$

Da base deste mesmo contato consigo, os cadernos de nota, surge um contato com outros, pois tais notas servem como matéria-prima para o que se relata por texto. Essas correspondências, também são um exercício pessoal: "É que, recorda Sêneca, quando escrevemos (uma missiva), lemos o que vamos escrevendo exactamente do mesmo modo como ao dizermos qualquer coisa ouvimos o que estamos a dizer.A carta enviada actua, em virtude do próprio gesto da escrita, sobre aquele que a envia, assim como actua, pela leitura e releitura, sobre aquele que recebe. ${ }^{, 14} \mathrm{Se}$, dessa forma, essa dupla função se aproxima dos hypomnemata, esse contato com outrem, com o Outro, também já molda essa consciência, pois o olhar deste outro implica numa responsabilidade e na escolha daquilo que vai ser dito. A maneira como esse escritor se faz "presente" passa pelo crivo dele próprio e por como ele imagina que o destinatário o perceberá: “Escrever é pois, 'mostrar-se', dar-se a ver, fazer aparecer o rosto próprio junto ao outro." ${ }^{15}$ Desta forma, aqueles hypomnemata, se são

\footnotetext{
${ }^{12}$ Ibidem, p. 137.

13 Ibidem, p. 137.

${ }^{14}$ Ibidem, p. 145.

${ }^{15}$ Ibidem, p. 150.
} 
encarados como uma subjetivação de elementos objetivos, são a base das correspondências, que, grosso modo, podem ser consideradas como objetivação de elementos já subjetivos:

Num caso - o dos hypomnemata - tratava-se de se constituir a si próprio como sujeito de acção racional pela apropriação, a unificação e a subjectivação de um 'já dito' fragmentário e escolhido; no caso da notação monástica das experiências individuais, tratar-se-á de desentranhar do interior da alma os movimentos mais ocultos, de maneira a poder libertar-se deles. No caso da narrativa epistolar de si próprio, trata-se de coincidir o olhar do outro e aquele que se volve para si próprio quando se aferem as acções quotidianas às regras de uma técnica de vida. ${ }^{16}$

Na Idade Média o espaço previsto para o isolamento do sujeito praticamente inexiste, pois a própria organização social e econômica cria dois espaços: um, fixo, murado, em torno do lar, em que os indivíduos compartilham do mesmo espaço e dos mesmos segredos e outro, desloca-se no espaço publico, hierarquizado e controlado pela mesma lógica que também deverá reger o ambiente familiar:

A sociedade feudal era de estrutura tão granulosa, formada de grumos tão compactos que todo indivíduo que tentasse se libertar do estreito e muito abundante convívio que constituía então a privacy, isolar-se, erigir em torno de si sua própria clausura, encerrar-se em seu jardim fechado, era imediatamente objeto, seja de suspeita, seja de admiração, tido ou por contestador ou então por herói, em todo caso impelido para o domínio do "estranho", o qual, atentemos às palavras, era antítese do "privado". Quem se retirava a essa distância, com efeito, se não era deliberadamente para fazer o mal, estava destinado, a despeito de si mesmo, a fazê-lo inevitavelmente, por seu próprio isolamento que o tornava mais vulnerável aos ataques dos Inimigos. Só se expunham dessa maneira os descaminhados, os possuídos, os loucos: segundo a opinião comum, um dos sintomas da loucura era vaguear sozinho. Testemunha-o a atitude em relação aos homens e às mulheres sem escolta com quem se cruzava pelos caminhos: eles próprios se ofereciam como presa; tinha-se o direito de tomar-lhes tudo; em todo caso, era obra pia reintroduzi-los, embora se irritassem, em uma comunidade, restabelecê-los à força no espaço ordenado, claro, gerido como apraz a

${ }^{16}$ Ibidem, p. 160. 
Deus, dividido entre as cercas do privado e as áreas intersticiais, públicas, onde as pessoas se deslocam em cortejo. ${ }^{17}$

Tal situação só mudará de fato, quando sábios do final do século XII, meditando sobre o texto da Escritura, percebem a idéia perturbadora de que a salvação não é alcançada apenas pela participação em ritos, mas é "ganha" pela transformação de si mesmo: "É um convite à introspecção, à exploração da própria consciência, pois que a falta já não parece residir no ato mas na intenção, e se considera que ela se refugia na intimidade da alma.Para o interior do ser, em um espaço que não tem mais nada de comunitário, transportam-se os procedimentos de regulação moral" ${ }^{18}$ Surgirá com isso, a idéia do anacoreta, um grau superior de perfeição a que se chegava na solidão, "ponto extremo da fuga fora do mundo carnal a que o monge era convidado". ${ }^{19}$ Surgirão também, com menos intenções ascéticas, porém também como uma busca de autonomia pessoal, neste final do século XII, as autobiografias: “(...)essas obras literárias afirmam com brilho a autonomia da pessoa, senhora de suas próprias lembranças, como o é de seu próprio pecúlio. O eu reivindica uma identidade no seio do grupo, o direito de deter um segredo, distinto do segredo coletivo."20

A Vita Antonii de Atanásio apresenta a notação escrita das ações e dos pensamentos como um elemento indispensável da vida ascética: "Eis uma coisa a observar para se ter a certeza de não pecar. Que cada um de nós note e escreva as acções e os movimentos da nossa alma, como que para no-los dar mutuamente a conhecer e que estejamos certos que, por vergonha de sermos conhecidos, deixaremos de pecar e de trazer no coração o que quer que seja de perverso. Pois quem consente ser visto quando peca, e após ter pecado, não prefere mentir para ocultar a sua falta? Não fornicaríamos diante de testemunhas. Do mesmo modo, escrevendo os nossos pensamentos como se o tivéssemos de comunicar mutuamente, melhor nos defenderemos dos pensamentos impuros por vergonha de os termos conhecido. Que a escrita tome o lugar dos companheiros de ascese: de tanto enrubescermos por escrever como por sermos vistos, abstenhamo-nos de todo o mau pensamento. Disciplinando-

\footnotetext{
${ }^{17}$ DUBY, Georges. A Emergência do Indivíduo.Trad. Maria Lucia Machado. In: DUBY, Georges (Org.). História da Vida Privada, 2: Da Europa feudal à Renascença. 13. ed. São Paulo: Companhia das Letras, 1990.Título Original: Histoire de la vie privée, vol.2: De l'Europe féodale à la Renaissance. , p.504

${ }^{18}$ Ibidem, p. 506.

${ }^{19}$ Ibidem, p. 508.

${ }^{20}$ Ibidem, p. 507-508.
} 
nos dessa forma, podemos reduzir o corpo à servidão e frustrar as astúcias do inimigo." 21

A escrita de si mesmo aparece aqui claramente na sua relação de complementaridade com a anacorese: atenua os perigos da solidão; dá o que se viu ou pensou a um olhar possível; o facto de se obrigar a escrever desempenha o papel de um companheiro, ao suscitar o respeito humano e a vergonha; podemos pois propor uma primeira analogia: aquilo que os outros são para o asceta numa comunidade, sêlo-á o caderno de notas para o solitário. Mas, simultaneamente, uma segunda analogia se coloca, referente à prática da ascese como trabalho não apenas sobre os actos mas, precisamente, sobre o pensamento: o constrangimento que a presença alheia exerce sobre a ordem da conduta, exercê-lo-á a escrita na ordem dos movimentos internos da alma. $^{22}$

Decisiva para legitimar o isolamento do indíviduo, a transformação do ato penitencial, que no início deve ser público e ocasional, torna-se obrigatório, periódico e, mais importante, discreto. ${ }^{23}$ Para as mentalidades da época, foi uma grande revolução: de fato, o efeito será a instauração da idéia do indíviduo, do privado, do espaço intimo. O espetáculo que se promovia de purificação, de exame de consciência, que exigia todo um aparato social para se realizar na cena pública, torna-se um simples diálogo, o "dos exempla, entre o pecador e o padre, isto é, entre a alma e Deus, confissão auricular, de boca e ouvido, um segredo, inviolável, importando a confissão apenas se desse início a um trabalho de correção, de desbastamento encetado pela pessoa, em silêncio, no interior de si mesma."24

Tal libertação da alma, e consequentemente, um maior exame de consciência começara de fato a ser sentida somente no final da Idade Média. Neste período, as grandes cidades já estão consolidadas e a escrita ali, mais do que nos burgos rurais, difunde-se entre privilegiados, mas a atitude mental em relação à esta escrita de fato muda: ela pode ser laica e privada, e mais importante, torna-se um hábito, o que leva Philippe Braunstein chamá-lo de "difusão de espelhos" $"$ :

\footnotetext{
${ }^{21}$ SANTO ANTANÁSIO, Vida e conduta de nosso pai Santo António, trd. Franc. Lavaud, \$55.

${ }^{22}$ FOUCAULT, Michel. Op. cit., p.130-132.

${ }^{23}$ Esclarece-nos Duby que tal mudança foi motivado por uma decisão do IV Concílio de Latrão, de 1215.

${ }^{24}$ DUBY, Georges, op.cit., p.525.

${ }^{25}$ BRAUNSTEIN, Philipe. Abordagens da intimidade nos séculos XIV-XV. Trad. Maria Lucia Machado. In: DUBY, Georges (Org.). História da Vida Privada, 2: Da Europa feudal à Renascença. 13. ed. São Paulo: Companhia das Letras, 1990.Título Original: Histoire de la vie privée, vol.2: De l'Europe féodale à la Renaissance, p. 527.
} 
Não se fala de si sem justificações; os Provérbios, Aristóteles e santo Tomás são autoridades suficientes para limitar as ocasiões de começar um relato na primeira pessoa. Para vários autores, a autobiografia liberta de toda coerção nasce com a Idade Moderna, que inventa um registro da narrativa de si mesmo independente da história e da apologética. É bem evidente que, descobrindo-se no centro do universo entre os dois infinitos, o homem exulte por ter recebido de Deus a faculdade de realizar-se em suas virtualidades e em suas inclinações: a autobiografia proclama a dignidade dos destinos singulares. Mas o relato de si mesmo não saiu todo armado da cabeça de heróis legitimados; libertou-se progressivamente de formas narrativas que põem em cena o indivíduo socializado, os prazeres e as dores da existência inspirando ao autor a irresistível vontade de dar sua palavra, quer ele assinale que estava à margem da estrada por onde passava a história, quer incorpore à rapsódia anotações privadas, quer coloque sob o olhar de Deus uma aventura exemplar que põe em cena suas próprias tribulações. Em suma, o jogo do "eu" com o "si mesmo" revolucionado é oriundo seja do modelo agostiniano da confissão, seja da preocupação de anotar no dia-a-dia aquilo que um bom administrador deve conservar no espírito para si mesmo e para os seus, seja do registro dos fatos memoráveis no mundo e ao alcance de si. A confissão, o diário, a crônica são, no final da Idade Média, fontes de informações em que o indivíduo apresenta por vezes sobre sua vida privada, isto é, sobre seu corpo, suas percepções, seus sentimentos e sua concepção das coisas, apanhados sinceros, tanto quanto pode sê-lo uma memória redescoberta que pretende "pintar o ser de frente e não de perfil". ${ }^{26}$

A prática do diário não para de crescer durante toda a era clássica. Transmuta-se nos diários de depoimentos urbanos, diários de viagens, formas amplificadas daqueles livre de raison. A visão do sujeito adquire importância inédita, pois esta e as palavras de quem a porta são a garantia da verdade do que é dito. De simples escriba de fatos objetivos ou reminiscências subjetivas causadas pelo objetivo, o sujeito se constitui ele mesmo fundamento da verdade daquilo que anuncia. Paradoxalmente, esta verdade contida no diário, de uma visão externa, pertence ao não-público, ao privado, ao íntimo: “A verdade não tem de ser demonstrada, provada, ela não se refere aos atos públicos do sujeito, não pertence ao grupo, aos depoimentos majoritários, pertence inteiramente a esse olhar individual, à margem, quase

\footnotetext{
${ }^{26}$ Ibidem, op.cit., p. 533.
} 
secreto, lançado sobre as coisas e o mundo. E é desse privilégio que o autor do diário está consciente quando se põe a redigi-lo."27

Mas será de fato depois da instauração da imprensa, e consequentemente, da disponibilização de meios em que o privado se torne público, principalmente através dos romances, que a questão do que é privado e o que é de domínio público tornam-se questões ambíguas. Se o diário é publicado, como pode ser ele íntimo, na acepção da palavra, e principalmente, como se esperar ali um sujeito isento do meio, se é para este meio que ele escreve? Mesmo o uso do mise-en-scène com o intuito de se criar uma visão "verdadeira" dos fatos, como manuscritos encontrados em sótãos ou num baú (Robinson Crusoe, La Vie de Marriane), as cartas remetidas ou descobertas (Ligações Perigosas), tentam negar o caráter romanesco, refundamentanto o autor enquanto escriba: "O que equivale a dizer que é por se apresentar como discurso espontâneo, como ato sob forma de discurso, produzido por um não-escritor, não destinado à publicação, que o romance pode passar por verdadeiro."28 $\mathrm{O}$ efeito de verdade se desloca para a relação entre o sujeito que escreve e o sujeito que lê. Nesse ponto, torna-se diluído aquele caráter de encontro deste Eu consigo mesmo. Há um novo elemento: o Outro, alguém que, propositalmente, compartilhará deste encontro. E criam-se novas formas de se convencer este Outro da veracidade declarada por este Eu:

Poderíamos reduzir o Iluminismo a sua invenção pedagógica. No sentido em que, para atingir seu público, o discurso iluminista inventa formas novas: castas, dicionários, contos filosóficos. Talvez seja esse o traço predominante da época. Essa invenção narrativa e enunciativa é acompanhada de uma busca de legitimidade. O homem do Iluminismo não pára de se questionar sobre seu direito à palavra e suas relações com a verdade. Sabemos que ele não escapou à tentação de substituir o padre. As alusões de Voltaire à "nova Igreja" não são tão inocentes como pretendem alguns. Não se trata de ver em Voltaire um crente que se ignoraria, mas, antes, de avaliar o peso dos modelos das representações predominantes na ideologia do Iluminismo e na imagem de si mesmos que os iluministas criaram para legitimar seu combate. Sob este aspecto, é esclarecedora a definição que o filósofo dá de si mesmo. Ele quer estar no mundo. "A sociedade civil é, por assim dizer, uma divindade na terra para ele", afirma

${ }^{27}$ GOULEMOT, Jean Marie. As práticas literárias ou a publicidade do privado. Trad. Hildegard Feist. In: ARIÉS, Philippe; DUBY, Georges (Org.). História da Vida Privada 3: Da Renascença ao Século das Luzes. 13. ed. São Paulo: Companhia das Letras, 1990.Título Original: Histoire de la vie privée, vol 3: De la Renaissance aux Lumières, p. 392.

${ }^{28}$ Ibidem, p. 393. 
a Encyclopédie no verbete "Filosófico". Ele fundamenta a verdade de suas proposições na razão, da demonstração e na observação. Nele se aliam um dom da natureza, um método de trabalho, diz ainda a Encyclopédie. ${ }^{29}$

Longe de afirmar que a verdade só é encontrada pela Razão ou inspirada por Deus, Rousseau afirmará que a verdade está no fim de uma procura que é uma ascese social e moral. Mas tal procura, como entendido essa ascese, pressupõe uma liberdade que somente o distanciamento a qualquer vínculo social, entre eles o ideológico, ou entre o Eu e o Outro. A verdade, neste caso, só pode ser dita ao mundo, quando se está desvinculado dele. A moralidade, de certa forma, existe enquanto contraponto da consciência de inocência deste Eu em relação à inteligência fundamentada no objetivo:

Enfrentando seus detratores, Rousseau não cessa de opor-lhes a moralidade de sua conduta. Acaba por afirmar que sozinha, ou pelo menos em amplo aspecto, ela fundamenta a verdade de seu sistema filosófico. Nos diálogos de Rousseau juge de Jean-Jacques apresenta um inquérito que tende a demonstrar pela mediação de sua retidão moral a verdade de sua filosofia. Equivale a dizer que a moralidade é para a verdade filosófica o que o raciocínio é para a exatidão filosófica. Passou-se do privado para o íntimo. $\mathrm{O}$ inquérito dos diálogos tem por objetivo a vida privada do filósofo, seus atos, sem dúvida, mas também seus pensamentos. Pelo viés das testemunhas e inquisidores, a escrita revela a intimidade do ser. A moral então é concebida menos como uma codificação das relações entre os indivíduos que como um sentimento de inocência do eu. Tal processo, que consiste em transferir o critério de verdade de normas exteriores (validade do raciocínio, conformidade à razão...) para uma convicção íntima e uma intuição do eu, conhecerá o sucesso no século XIX. ${ }^{30}$

Daquela outra definição de intimismo, a mais técnica, temos imediatamente que a noção de identidade individual implica na constituição e definição do sujeito. Ora, tal constituição, neste século XIX, passa, necessariamente pela tentativa deste sujeito também se diferenciar desta massa que cresceu urbanizada principalmente. A Revolução Industrial causa esse inchaço, de anônimos, que lotam os espaços públicos, como cafés, as casas de comércios, os pátios coletivos dos cortiços. O sujeito, na tentativa de se isolar busca não só o recolhimento - notados em pinturas da época em que avultam imagens desse individuo

\footnotetext{
${ }^{29}$ Ibidem, p. 397.

${ }^{30}$ Ibidem, p. 399.
} 
isolado, solitário, no canto da janela da sala, nos seus aposentos, no escritório intimo, entre a casa e o jardim. ${ }^{31}$ Mas talvez, o maior indício desta luta contra a massificação, contra o anonimato imposto pela multidão, e a tentativa de encontrar seu lugar no mundo e manter-se enquanto indivíduo seja a questão do nome. Nomear se torna uma espécie de registrar-se perante os outros, separando-se deles, evitar ser confundido com eles. Há, claro, o lado prático disso, mas certamente o lado individualizante também é levado em consideração:

Ao longo de décadas, ciclos mais ou menos curtos, estabelecidos pela moda, dão o ritmo do movimento de dispersão; esta aceleração traduz simultaneamente a acentuada vontade de individualizar, a preocupação em sublinhar o corte das gerações e o desejo de adaptar-se à nova norma, sugerida pelas classes dominantes. Com efeito, a moda de certos prenomes propaga-se verticalmente, da aristocracia para o povo, da cidade para o campo. A precisão e complicação crescentes da hierarquia social favorecem a transmissão de tais modas por capilaridade. Ao mesmo tempo, as regras de transmissão familiar dos nomes perdem sua autoridade. A escolha do prenome do padrinho ou da madrinha, ou seja, tradicionalmente, de um dos avós, um tio-avô ou uma tia-avó, a passagem do prenome do pai ao filho primogênito ou do avô falecido ao neto recém-nascido constituem, especialmente no campo, imperativos cujo declínio certamente não convém exagerar; nem por isso deixam de ser contrariados pelas novas práticas de ascensão. $\mathrm{O}$ enfraquecimento das regras de transmissão familiar traduz o definhar das virtudes hereditárias e ao mesmo tempo vaticinadoras do prenome. A perda da fé na existência de um patrimônio de caráter transmitido pela denominação evidentemente trabalha a favor do individualismo. ${ }^{32}$

Vê-se que, ao longo da história, que variam, no dizer de Clara Rocha "as coordenadas que servem de pano de fundo à produção literária, diferenciam-se as situações de enunciação e de recepção, os múltiplos canais dão novos contornos aos gêneros autobiográficos, acumulam-se as experiências da escrita" ${ }^{33}$. No fundo trata-se sempre deste procurar o lugar do $e u$ no mundo. Assim, se a idéia da autobiografia é estabelecer o $e u$ no mundo, a idéia da poesia intimista, é, além disso, estabelecer quem é este eu e como este eu se estabelece no

\footnotetext{
${ }^{31}$ FERNANDES, Annie Gisele, op.cit., p.185.

${ }^{32}$ CORBIN, Alain. O segredo do indivíduo.Trad. Denise Bottmann e Bernardo Joffily. In: PERROT, Michelle(org.).História da Vida Privada 4: Da Revolução Francesa à Primeira Guerra.10 ed.reimp.São Paulo: Companhia das Letras, 2006. Título Original: Historie de la vie privée, vol 4: De la Révolution à la Grande Guerre, p. 419.

${ }^{33}$ ROCHA, Clara. Máscaras de Narciso: Estudos sobre a literatura autobiográfica em Portugal. Coimbra: Almedina. 1992, p. 44.
} 
mundo, como vê o mundo, e como se constitui ali. É como um jogo: O autor constitui um Eu que se constitui dentro do poema:

Tomado como construção textual, o eu revela-se, ele próprio, tecido ou estrutura. A literatura da modernidade proclamou a multiplicidade do eu, acompanhando, aliás, a desconstrução que também o pensamento moderno fez da pretensão fundadora atinente ao Cogito cartesiano. (...) E não é por acaso que a idéia da multiplicidade dialogante do $e u$, tal como a modernidade literária a exaltou, foi retomada pela crítica estruturalista e pós-estruturalista que se interessou pela literatura autobiográfica. (...) No plano estético, o herói autobiográfico é uma recriação, a combinação entre uma pessoa real e uma personagem inventada, o resultado de um processo simultaneamente de auto-descoberta e de modelação de uma imagem. No plano narratológico, o eu que fala já é um outro, mantém com o eu de quem fala uma relação distanciada, patente sobretudo nos gêneros que pressupõem uma narração ulterior, como a autobiografia ou as memórias. Nessas modalidades de escrita autocentrada existe um desvio temporal entre o $е u$ passado e o $e u$ presente, entre o actor e o autor da enunciação.(...) O relato autobiográfico seria, nesta óptica, a história dum passado pensada e falada por um narrador que se lembra do que viveu. No plano gramatical, o eu diz-se em várias pessoas. A primeira é obviamente a mais usada.Por último, não é de menosprezar a relação dialogante que o sujeito autobiográfico mantém com o intertexto. $\mathrm{O} e u$ é afectado pelo outro de muitas maneiras, e uma delas é sem dúvida a influência que nele exercem os modelos de identidade que a tradição cultural oferece. $(\ldots)^{34}$

Tendo por base teórica as idéias expostas, durante o próprio desenvolvimento das análises outras foram acrescentadas, aproveitando-se do momento da própria leitura para se refletir a idéia da constituição deste $e u$ e como, particularmente, Cesário parece caminhar em direção ao próprio questionamento da validade desta constituição e consequentemente de si mesmo. Por isso, o critério adotado de escolha do corpus em princípio teria que concluir necessariamente com o poema Nós. É que, na nossa visão, o poema em si e sua conclusão parece ser um corolário e um Epitácio definitivo na idéia de que, com a sua constituição este $e u$ se encontraria e se harmonizaria perante um mundo desarmonizado. O que se vê é, de fato, o que chamamos de desconcerto do eu, uma conclusão plausível após o acompanhar desta caminhada.

\footnotetext{
${ }^{34}$ Ibidem, op.cit, p. 48-50.
} 


\title{
Do risível amor de si ao desastre do Outro
}

\author{
"Comigo me desavim, \\ sou posto em todo perigo; \\ não posso viver comigo \\ nem posso fugir de mim. \\ Com dor, da gente fugia, \\ antes que esta assi crescesse; \\ agora já fugiria \\ de mim, se de mim pudesse. \\ Que meio espero ou que fim \\ do vão trabalho que sigo, \\ pois trago a mim comigo, \\ tamanho imigo de mim?" \\ (Sá de Miranda)
}

O constante uso da ironia, não raras vezes do escárnio puro e outras tantas da autoflagelação, se constituem, de acordo com a intenção desta análise, não só as primeiras 'pinceladas' autorais de Cesário, mas um recurso estilístico de extrema importância para seus poemas. É através deste recurso que, em seus trabalhos inicias, o Eu se permite esconder atrás do contraste entre a enunciação do tema, o seu desenvolvimento e a conclusão que desconstrói o que foi até então dito ${ }^{35}$. Esconde-se atrás do riso, mas esconde-se também de si, já que este Outro não pode ser nada além de sua extensão ${ }^{36}$. A escolha pela perspectiva intimista, como já tratado anteriormente, permite este tipo de leitura: mesmo quando se centra no Eu enquanto persona, no Outro como um personagem e nas relações entre eles como um

\footnotetext{
35 "De modo genérico, a ironia consiste em dizer o contrário do que se pensa, mas dando-o a entender. Estabelece um contraste entre o modo de anunciar o pensamento e o seu conteúdo. De onde aproximar-se da antífrase. A ironia funciona, pois, como processo de aproximação de dois pensamentos, e situa-se no limite entre duas realidades, e é precisamente a noção de balanço, de sustentação, num limiar, a sua característica básica do ponto de vista da estrutura."MOISÉS, Massaud. Dicionário de Termos Literários.19. ed. São Paulo: Cultrix, 2000, p. 295.

36 "O Outro sempre desempenha na vida do indivíduo o papel de um modelo, de um objeto, de um associado ou de um adversário."FREUD, Sigmund. Dicionário Filosófico de citações. In: GRATELOUP, Leon-Louis (org.). Trad. Marina Appenzeller. São Paulo: Martins Fontes, 2004.Título original: Dictionaire philosophique de citations, p. 83
} 
terceiro objeto, se está a meio caminho de uma visão totalizante, ou melhor, uma visão que abrange estes elementos sempre voltados para a caracterização da escrita do autor, e como isso determina a estilização do Eu.

$\mathrm{O}$ Eu que se percebe nos primeiros poemas publicados é um Eu impossibilitado de poder compartilhar do amor do Outro. São dois motivos pelos quais este 'amor' não se consuma: o primeiro é sê-lo demasiadamente carnal, e o segundo, pelo Eu, hesitante, se constituir ainda num Eu não definido. O amor carnal o atrai, o sufoca, o enforcará. Aquele que imagina ser o seu ideal, um amor de adoração, distante, sublime, não será encontrado. Assim, o Eu encontra desde já seu primeiro ponto de fragmentação: $\mathrm{O}$ amor que o Eu procura é o Amor Ideal, mas o que encontra é o amor real, carnal. Seu amor ideal encarna-se na doce mulher, na Vênus linfática. Por esta perspectiva, a ironia não é somente esperada, como a única saída razoável para o Eu fugir intacto deste contato "danoso". A ironia, neste sentido, também mereceu importante estudo de Janet Carter: "O tom de ironia mordaz(...) sugere certa inquietação psicológica ou conflito emocional quanto à situação amorosa. A tensão que assim se evidencia entre o querer e o não querer tem o seu paralelo temático no conflito que se manifesta na reacção do 'eu' perante a figura feminina em geral."37 O Outro, enquanto mulher, deveria se constituir apenas num espelho para o Eu engrandecer-se e olhar-se com garbo e altivez. A ironia é o escudo contra tal erotismo, mas é também a possibilidade do Eu se relacionar com o Outro apenas em parte. É que, tal como usada nos poemas, a ironia é como um mea culpa do pecador flagrado no ato: confissão de uma culpa que se divide pela sedução do Outro. Fosse esse Outro puro, o deleite poderia acontecer no campo do Ideal.

Nem toda ironia, porém, em Cesário, trata deste tipo de relação ou tem somente este tipo de solução. A ironia, como a define Hegel, envolve um conhecimento da situação, permeada por um desprezo não somente ao objeto ironizado, mas também a si mesmo. ${ }^{38} \mathrm{O}$ Outro também se transmorfa, assim como o Eu avança nos domínios do seu autoconhecimento. No início, ele ainda é hesitante, juvenil, deleitoso dos prazeres carnais, recém descobridor de si enquanto ser. Se o Eu se imagina digno de adoração ("Já que adorar-

\footnotetext{
37 CARTER, Janet E. Cadências tristes. O universo humano na obra Poética de Cesário Verde. Lisboa: Imprensa Nacional - Casa da Moeda, 1989, p. 27.

38 "Essa virtuosidade de uma vida irônica e artística se concebe, pois, como genialidade divina, para a qual tudo e todos são apenas uma criação sem essência, na qual o criador livre, que se sabe desvencilhado e livre de tudo, não se prende, pois pode tanto destruí-la quanto criá-la.” HEGEL, G.W. F. Curso de Estética I. Trad. WERLE, Marco Aurélio; TOLLE, Oliver. São Paulo: EDUSP, 2000. Título original: Vorlesungen über die ästhetik. p. 82.
} 
me dizes que não podes”), puro (“Ò áridas Messalinas, Não entreis no santuário. Transformareis em ruínas, o meu imenso sacrário"), iluminado ("Lâmpada no mundo cavernoso") e se o Outro somente existe para ressaltar tais qualidades em contraposição pelos seus defeitos, tal relação tomará outros rumos quando o Eu abandonar o Amor de si e passar a dirigir seu olhar para o Outro. Até então, o foco sempre tem sido no Eu; um Eu doente de si e cheio de si, onde em seu mundo cavernoso o que não é Eu, é errado, é o Outro. A grande ironia se constitui então não no escárnio aberto e claro dos versos, mas a constatação de que se ri não do Outro ou das relações, mas de si mesmo. ${ }^{39}$

O Outro, além de funcionar como contraposição ao Eu, ressaltando-o, também é a ponte entre este Eu - mergulhado no amor de si, focado e entronizado somente em suas próprias reações e sensações - e uma realidade empírica, histórica e social, principalmente, porém, cultural. A "Imperatriz serena, alva e discreta" 40 não é uma traidora simplória qualquer, mas aquela que tem um peito de Herodes, assim como a "Vênus linfática" engana pelo simples instinto ou pela malícia, ludibria com a ajuda do Secretário das Amantes $^{42}$. Mais do que definir o Outro, a mulher sensual acaba por provocar o efeito oposto: O Eu constituído nestes poemas inicialmente tratados será enforcado, enganado ou profanado.

\section{Mas o que há-de apertar o meu pescoço ${ }^{43}$ \\ Em lugar de corda de bom linho \\ Será do teu cabelo um menos grosso ${ }^{44}$}

39 Denis de Rougemont dirá, sobre este tipo de amor: "Paixão quer dizer sofrimento, coisa sofrida, preponderância do destino sobre a pessoa livre e responsável. Amar o amor mais do que o objeto do amor, amar a paixão por si mesma, desde o amabam amare de Santo Agostinho até o romantismo moderno, é amar e procurar o sofrimento. Amor-paixão: desejo daquilo que nos fere e nos aniquila pelo seu triunfo. É um segredo cuja confissão o Ocidente jamais tolerou e não cessou de recalcar- de preservar." ROUGEMONT, Denis. História do Amor no Ocidente. Trad. Paulo Brandi ; Ethel Brandi Cachapuz. 2. ed. São Paulo: Ediouro, 2003, p. 68-69. Parece-nos que a ousadia de Cesário em descortinar o amor, ainda que licenciado pelo uso da ironia, demonstra desde já a sua originalidade.

${ }^{40}$ A edição que se utilizará para a análise dos poemas de Cesário Verde é aquela de Joel Serrão. VERDE, Cesário. Obra completa de Cesário Verde. SERR ̃̃O, Joel (org.). 8 ed. Lisboa: Livros Horizontes, 2003, p. 43.

${ }^{41}$ Ibidem, p. 44.

${ }^{42}$ Secretário das Amantes é um livro que contém modelos de cartas amorosas, muito em voga na época. Se pensarmos na questão de que somente a burguesia aprendia a ler e escrever, e tinha tempo para tal, ressalta-se o caráter irônico do enganado pelo 'ordinário'(modelos à disposição de todos) e não pelo particular (os sentimentos sinceros da amante).

4343 "Sendo uma forca o aparelho que serve para estrangulação, evoca-se, assim a idéia de suplício; suplício por sua vez, faz lembrar sofrimento, que tanto pode ser físico como espiritual ou moral. Por via metassintática, em função da imagem clássica do Colosso de Rodes do mesmo poema, pode-se atribuir ao suplício uma conotação igualmente clássica e surge, assim, algo reminiscente do suplício de Tântalo, que significa, figurativamente, o sofrimento moral e a inquietação da alma provocados pelo malograr de uma ambição no momento que vai ser satisfeita." CARTER, Janet, op.cit, p. 71. 
Mas ela em papel fino e perfumado,

Respondeu certas coisas deslumbrantes,

Que o puseram, ó céus, desapontado! ${ }^{45}$

\section{Ó áridas Messalinas}

Não entreis no santuário,

Transformareis em ruínas

O meu imenso sacrário! ${ }^{46}$

A caracterização desta mulher demonstra o amor-de-si que o Eu nutre. Se for para ser enganado, o será por mulheres virtuosamente hábeis, sensuais e mitológicas. Desta leitura, poder-se-ia pensar os escritos como o de um Eu que ainda não encontrou o amor fora do prazer, ou ainda sequer o encontrou, e suas elucubrações são de alguém que constrói um muro em defesa da sua crença (e o termo está correto, no sentido lato daquele que acredita sem a prova) contra o mundano, e numa atitude "heróica" anda sobre este mesmo muro, troçando do chão que tanto o atrai. Da leitura destas mulheres e suas caracterizações, o Eu demonstra e põe em dúvida o próprio caráter dessas relações, já que são estas, até então, idealizadas, e quando "consumadas" insuficientes para harmonizar e humanizar tais relações ${ }^{47}$ ("Vós sóis umas vis afrontas,/ Que nos dão falsos prazeres"). ${ }^{48}$

O poema Eu e Ela, à primeira vista, pode trazer a idéia de tal harmonia, mas o texto inteiro é construído com verbos no tempo futuro, e a ação é condicionada à presença de ambos num "mimoso jardim", e o final, irônico e contraditório, desconstrói toda a aparente solução harmônica entre o Eu e o Outro. Desconsiderando acreditar no voto que é proposto pelo Eu, já que incompatível a leitura de duas obras tão díspares ( $O$ Flos Sanctorum" e o "Cavaleiro de Faublas"), o que resta é a noção de que o tempo presente, o tempo em que o Eu

\footnotetext{
${ }^{44}$ VERDE, Cesário, op.cit, p. 43.

${ }^{45}$ Ibidem, p. 44.

${ }^{46}$ Ibidem, p. 45.

47 "Sem exceção alguma, todos os poemas deste período têm a mulher por objecto(sic) e o amor por tema. Mas um amor que se apresenta matizado dos mais diversos e opostos tons, que vai do amor consentido pelas 'áridas Messalinas', até à evocação de amores de adolescência desenhados na paisagem campestre, adquirindo por fim aspectos de amor inconsumado e inconsumável na adoração revoltada da citadina "Milady". SERRÃO, Joel. Cesário Verde: Interpretação, Poesias Dispersas e Cartas. 2 ed. Lisboa. 1957, p. 70.

${ }^{48}$ VERDE, Cesário, op.cit., p.45.
} 
olha para si, não contém a opção do conserto. Por isso as melancolias, a saudade de um outro tempo, dão o tom deste particular poema. A $1^{\text {a }}$ estrofe, um quarteto, tem um verbo com valor adjetivo e um verbo com valor adverbial, ambos sem a clareza do tempo verbal, pois um está no infinitivo e outro no gerúndio:

\section{Cobertos de folhagem, na verdura,}

O teu braço ao redor do meu pescoço,

O teu fato sem ter um só destroço,

O meu braço apertando-te a cintura; ${ }^{49}$

Mesmo sob a hipótese de tal quarteto referir-se ao presente, e assim, o gesto de uma união harmoniosa, representada pelos sinais externos do "fato sem ter um só destroço", permitir apontar a existência da união do Eu e o Outro, tal acontecimento carece de certas premissas: uma delas, notadamente, o mimoso jardim (onde não há gozos sensuais e nem as más idéias) e a outra, a mulher "digna" de acompanhar o Eu em tal deleite. Neste caso, ela não é mais a Messalina e sim a "pomba mansa" e seus cabelos estão ordenadamente em tranças, não revoltos e sequer servem como "linho de forca".

A leitura que se faz do mimoso jardim não foge daquela feita pela crítica estabelecida: Jardim do Éden, símbolo do Tempo de Ouro, o Campo ${ }^{50}$. Quaisquer que sejam os nomes dados ou as abordagens que permitem tal imagem, todas elas recorrem à idéia que só se efetiva enquanto antinomia do significante que representa a Cidade. É preciso entender que somente no bucólico campo, ou além do ambiente citadino, antinatural, haverá a esperança da harmonia. Parece-nos, no entanto, que não é tão somente o Campo: é também a presença de um Outro que, assim como tal lugar, carrega e simboliza a pureza, a harmonia e a força. É na presença deste Outro Puro que o Eu terá enfim um espelho que julgue digno de si.

Não é exagero, apesar das sutis diferenças, afirmar que o Outro em Cesário, quando gênero feminino, incorre sempre em dois: um, o impuro, aquela que faz com que as tentações carnais sejam mais importantes que a "elevação espiritual". Tais elevações não passam de

\footnotetext{
${ }^{49}$ VERDE, Cesário, op.cit., p. 46.

${ }^{50}$ Adiante, se tratará do tema e da dicotomia cidade-campo de forma mais acurada e fundamentada. Aqui, basta notar o início desta dicotomia considerada central na mentalidade do autor. Por hora, só se visualiza um 'jardinzinho'...
} 
uma desculpa para um possível desconcerto em relação ao elemento feminino e sensual. ${ }^{51} \mathrm{O}$ segundo, irreal, pois observada apenas enquanto parceira de um Eu que se imagina elevar pelo amor cortês, gentil e espiritualizado ${ }^{52}$.Assim como o primeiro tipo feminino, este também é apenas um espelho para um Eu ainda amante-de-si, que não visualiza outros modelos que não aqueles que sirvam como contraposição para a demonstração de sua altivez ou sua abnegação. De que nos parece óbvio que, neste ínterim, o poema Ele seja totalmente ausente da figura do Eu. Neste poema, há um narrador à moda da prosa, que observa um fato simplesmente e o narra, sem emitir qualquer opinião. Pode-se objetar com o argumento de que a narração também envolve uma predileção ou foco pessoal, e, sendo assim, também contém um Eu artístico. De fato, mas é um Eu que se preserva de se mostrar, nos parecendo ainda inseguro ou inconfortável com seus novos poderes: o olhar para fora de si. Até então, e enquanto este Eu estiver neste embate com o Outro feminino, o olhar será sempre direcionado para si, incluindo aí suas próprias convicções morais, e não menos importante, a representação que faz de si mesmo.

O que John Laidlar disse de Desastre, cabe, em grande medida, também ao poema em questão: este ganha importância pelos elementos estilísticos, mas perde, por outro lado, pela crítica que foge daquela ironia até então privilegiada. ${ }^{53}$ Parece que ao tratar de um Outro ainda pouco conhecido, este Eu ausente (ou, como dito anteriormente, camuflado de narrador e observador onipresente) não se apercebeu que sua própria condição de existência será

\footnotetext{
51 “(...) o seu ideal feminino parece ter sido, pelo menos nos princípios da sua actividade poética, a mulher glacial e distante(...). O poeta sente-se atraído pela 'belle dame sans merci' que tinha fascinado Keats e outros poetas românticos ingleses e franceses.(...)Estamos perante a femme fatale que tanto inquietou os artistas europeus na segunda metade do séc. XIX sob nomes variáveis: a Salomé de Wilde, a Carmen de Mérimée, a Salambô de Flaubert ou a Jeanne Duval de Baudelaire. A 'dame sans merci' de Cesário subjuga o adorador e concede-lhe apenas o papel de servo incondicional(...)." LIND, Geroge Rudolf. "O real e a análise”: o mundo poético de Cesário Verde. Colóquio Letras. No. 93. Setembro de 1986, p.31.

52 "Nos seus inícios ultra-românticos Cesário não se sente somente atraído pela femme fatale, mas também pelo pólo oposto desta, a femme fragile, a mulher etérea, angélica e quase santa, o ideal dos prerafaelitas ingleses." Ibidem, op.cit., p.32.

53 “Os defeitos da segunda metade de 'Desastre' são, essencialmente, os da imitação da ideologia poética da 'Escola Nova'. Nos versos de Antero (Odes Modernas), Azevedo (A Alma Nova), Junqueiro (A Morte de D. João), Gomes Leal (A Canalha), Barros de Seixas (Cantos Modernos), Bettencourt-Rodrigues (Ao combate) e outros há a mesma identificação clara, quando não simplista, das forças malévolas da sociedade que se encontra ao fim de 'Desastre'. Em 'Desastre' essa polarização das forças do bem e do mal talvez resulte, em parte, da crítica dirigida à poesia 'Esplêndida' por um arauto da 'Escola Nova', Teófilo Braga. A crítica de Teófilo baseou-se sobretudo n ausência, em 'Esplêndida', de condenação inequívoca da mulher altiva e anti-social que é a protagonista da poesia. As referências em 'Esplêndida', irônicas, embora, à sujeição do narrador à mulher arrogante ofenderam a moralidade de Teófilo. Ele e a 'Escola Nova' de poetas promoveram uma poesia séria, recta e moralista, que condenava a injustiça em palavras inconfundíveis e não com a ironia humorística empregada por Cesário em 'Esplêndida'." LAIDLAR, John. Na encruzilhada: 'Desastre' de Cesário Verde. Colóquio Letras. Lisboa. No. 93. Setembro de 1986, p. 54.
} 
colocada em xeque pelo meio. Mas só isso não explicaria o teor poético de Cesário. Não é somente esta 'encruzilhada' que o momento finissecular inspira na sociedade em geral que é lido nos poemas, mas antes, e retornando a linha mestra desta dissertação, a 'encruzilhada' pessoal que todo ser humano, enquanto biológico, social e moral se depara. Apesar destas encruzilhadas, buscar representar o Eu à medida que vai tomando conhecimento dele, independente de como ele é, e do juízo que se faça dele, recai naquilo que Nietzsche fala sobre a arte da alma feia:

"Estabelecem-se limites demasiado estreitos para a arte, ao exigir que apenas as almas regradas, moralmente equilibradas, possam nela se exprimir. Assim como nas artes plásticas, também na música e na literatura existe uma arte da alma feia, juntamente com a arte da alma bela; e os efeitos mais poderosos da arte - dobrar almas, mover pedras, humanizar animais - talvez tenha sido justamente aquela que os obteve melhor." 54

Tal Eu, rompido com seu reflexo, começa a visualizar as possibilidades do particular e do geral: o primeiro é ainda sua rede de segurança neste caminhar que vai ganhando passos cada vez mais largos, à medida que seus próprios conhecimentos vão se acumulando. Das figuras fáceis, de leituras imediatas, este Eu agora percebe as sombras que envolvem o Outro, as relações e a si mesmo. No poema Impossível, assim como anteriormente mostrado em Eu e Ela, tem-se a primeira impressão de um Eu em consenso com o Outro. Neste poema, este Outro é mais elaborado exteriormente, com sinais físicos e descrições de uma figura feminina, ("ombros desnudos", "olhos tão ramudos,/ Cor de azeitona escura", "faces cor-de-rosa e vermelhão" $)^{55}$ de hábitos e vestes citadinas. ${ }^{56}$ Não é somente, todavia, o uso de tais descrições e o desenrolar da trama que nos interessa. O final sarcástico faz eco com o título: Impossível não é deleitar-se sem responsabilidades. Impossível neste caso é o Eu decidir por um tipo de contrato pessoal, que é também social. Mas será que se trata apenas de uma

\footnotetext{
${ }^{54}$ NIETZSCHE, Friedrich. Humano, demasiado humano: um livro para espíritos livres. Trad. Paulo César Souza. São Paulo: Companhia de Bolso, 2005. Título do original: Menschliches, Allzumenschliches. Ein Buch für freie Geister, p.110.

${ }^{55}$ VERDE, Cesário, op.cit., p. 46.

${ }^{56}$ Helder Macedo nota, através de tais descrições da mulher : “'Impossível' é uma equivalente imagem de espelho que reflecte uma convencional felicidade doméstica só possível desde que não oficializada pelas fórmulas legais do matrimônio. O ninho boêmio onde os amantes conduzem a sua burguesíssima vida clandestina é um espaço idílico de 'bolos e presuntos', um lócus amenus cuja própria ilegalidade serve também para jocosamente neutralizar qualquer outra responsabilidade social." MACEDO, Helder. Nós: uma leitura de Cesário Verde. 4 ed. Lisboa: Editorial Presença, 1999, p. 71.
} 
posição legal, ou seria também possível ver uma posição moral ? $^{57}$ Possivelmente ambos os casos, mas importa notar como esse Eu dialoga de forma mais segura com outros elementos que não somente seus próprios desejos: há um desejo do Outro, não expresso, porém visível, de regularizar uma situação ilegal (ou imoral), em contraposição as promessas de um relacionamento 'perfeito', em que nada falte, quer seja material, quer seja espiritual:

Eu tudo posso dar-te, tudo, tudo,

Dar-te a vida; o calor, dar-te cognac,

Hinos de amor, vestidos de veludo,

E botas de duraque

Há um outro dado curioso neste poema: o Eu promete por si, e empenha sua palavra por oito vezes (há oito vezes a palavra 'posso'), enquanto o uso da palavra 'podemos', se dá exatamente na metade das ocasiões (4 vezes). Por essa perspectiva, poder-se-ia dizer que o Eu mostra-se sujeito aos caprichos do Outro, pelo anteriormente demonstrado, mas a única condição de fato, a única ação que o Eu deveria cumprir para satisfazer o Outro, ele não quer cumprir. Estabelecida a ironia, desde o título, percebe-se que o Eu, amante deste Outro, se utiliza inclusive de uma frase que foge do lirismo até então utilizado: "Lá nessa é que eu não caio!", expressão de forte oralidade e de tom casual, como se a 'sinceridade' deste Eu pudesse se provar pela demonstração de surpresa subtendida no tom jocoso. "Nós podemos viver alegremente", diz tal $\mathrm{Eu}$, condicionando não o presente, mas um futuro que não ocorrerá, à fuga das "mãos sacerdotais". No tempo presente, em que o Eu responde ao Outro, tudo que há é o desacordo.

O soneto Lágrimas, assim como o poema anterior, faz parte de um conjunto de 4 poemas, com o título de Ecos do Realismo, publicados no Diário da Tarde de 21 de Janeiro de 1874, no Porto. Neste poema, o Outro ainda é a mulher, porém aqui sofredora e descontrolada:

\footnotetext{
57 "Eis as forças em conflito: de um lado, uma moral da espécie e da sociedade em geral, mais ou menos impregnada de religião - é aquilo que se chama de moral burguesa; do outro lado, uma moral inspirada pelo meio cultural, literário, artístico - é a moral passional ou romanesca. Todos os adolescentes da burguesia ocidental são educados para o casamento, mas ao mesmo tempo vivem imersos numa atmosfera romântica proporcionada por leituras, pelos espetáculos e por mil referências quotidianas, cujo sentido subliminar é mais ou menos o seguinte: a paixão é a experiência suprema que todo homem deve um dia conhecer, e somente aqueles que 'passarem por ela' poderão viver a vida em plenitude. Ora, a paixão e o casamento são por essência incompatíveis. Suas origens e seus objetivos excludentes.” ROUGEMONT, Denis de, op.cit., p. 372.
} 


\section{Ela chorava muito e muito, aos cantos,}

Frenética, com gestos desabridos;

Nos cabelos, em ânsias desprendidos,

Brilhavam como pérolas os prantos. ${ }^{58}$

Nota-se que o poema não tem um Eu formal, mas um eu personalizado na terceira pessoa, que permite o tipo de comportamento cruel. Deslocado para a posição de observador, este $\mathrm{Eu}$, ao comentar e adjetivar os personagens de tal drama revela sua 'posição' moral e sua 'posição social': moralmente, ele se vê (ou é visto) santo ("sereno como os santos") e socialmente, superior à amante. Por isso, sua posição é confortável, ("Deitado no sofá, pés aquecidos"), enquanto ela fica aos cantos. Helder Macedo chamará a atenção para a simbologia sexual da água, degradada, pois utilizada para funções higiênicas, além de um desdém masculino pela mulher. ${ }^{59}$ Tal função permite a compreensão não somente no âmbito epidérmico, mas também no patamar espiritual: ao sentir que a mulher chorava, entoava alegres cantos, como um homem de bem. Ora, o impacto sádico de tais versos e a inversão de valores (caridade $\mathrm{X}$ desprezo), (Solidariedade X Egoísmo), demonstra não um Eu doente, mas antes, um Eu fruto de seu tempo, e, por isso mesmo, a já citada mea culpa que a ironia possibilita, revela-se agora um componente de crítica a esse mesmo produto,e indiretamente, ao seu produtor ${ }^{60}$. Um mundo desconsertado só poderia produzir indivíduos desconsertados. Á maneira dos realistas, seu quadro seria apenas uma representação comentada de dramas comuns, o que explicaria a falta de motivo do choro da mulher: não há necessidade de explicitar. Ela é amante numa sociedade patriarcal, em que o homem apenas cumpre seu papel de forte, e, tal qual um santo, lava suas mãos para a 'fatalidade' do destino. ${ }^{61}$

\footnotetext{
${ }^{58}$ VERDE, Cesário, p. 55

59 “Com efeito, 'Lágrimas' e, sobretudo 'Heroísmos' revelam uma atitude já não apenas jocosa (como ainda é em 'Cinismos') mas sarcasticamente perversa de desdém masculino pela mulher usada sexualmente: a simbologia sexual da água e do mar é degradada nestes poemas para sugerir uma função meramente higiénica (as lágrimas da amante aflita servindo para um banho de água salgada ao amante indiferente). (...)" MACEDO, Helder, op.cit, p. 72.

60 "O artista "satânico" - produto da sociedade urbana do século XIX - é, como Baudelaire, não conformista apenas na media em que se identifica com um Lúcifer concebido como contestatório e intransigente. Mas aceita os conceitos de bem e mal nos termos propostos pela sociedade e está consciente do 'frisson' provocado pela sua atitude e do valor de escândalo da sua obra. Com efeito, Baudelaire não propõe uma alternativa ética parta a sociedade corrupta que retrata: a sua obra reflete uma atitude pessoal e não social, uma atitude revoltada e não revolucionária. É uma negação que implicitamente reinstitui a norma que está a atacar.” Ibidem, p. 75-76.

61 "A lavagem, pois, simboliza menos a purificação do mal objetivo e exterior, que os males subjetivos que poderíamos chamar de 'particulares'. Torna-se óbvio acrescentar que esta purificação é muito mais difícil e dolorosa, posto que o que se trata de destruir forma conexão com a própria existência, suas razões vitais e
} 
Este Eu, até então estilizado apenas em confrontação com motivos amorosos, começa a ter outros motivos, ainda que de mesma raiz, para se testar: o mundo ganha agora não só as calçadas. De fato, este mundo ainda não saiu da alcova, mas os personagens agora vêm de fora, entram sem pedir licença no universo deste Eu abalroado por idéias e morais distantes daqueles ideais de um tempo mais inocente. O tempo destes poemas, utilizando a idéia do título "Ecos do Realismo", é um tempo passado, confinado no além deste aquém que a alcova e a ausência da visão do público permitem que venha à luz. O confinamento, que pode ser lido como antinomia da vastidão, caracteriza-se como citadino, burguês, por todos os traços que os adjetivos aqui e ali permitem supor. Mas é um confinamento, antes de qualquer coisa, que pertence a este Eu e suas adesões aos personagens, através destes mesmos adjetivos (o amante tal qual Dante de Impossível, o santo sereno de Lágrimas, o objeto de prazer e do furor da amante moderna de Proh Pudor). A vontade de desvendar aos olhos do público seus desejos mais secretos e mesmo suas intenções mais confusas, é evidente nos primeiros versos de Manias:

O mundo é velha cena ensangüentada,

Coberta de remendos, picaresca;

A vida é chula farsa assobiada, Ou selvagem tragédia romanesca ${ }^{62}$

O mundo e a vida enquanto representação, ou enquanto apresentada aos olhos de todos, tal como um espetáculo ('cena ensanguentada', 'picaresca') ou uma obra('farsa assobiada', 'tragédia romanesca'), só pode contar com atores ou personagens que cumpram seu script de forma fiel. Daí o bom rapaz e a déia. A atitude deste rapaz em levar sua amante à missa, tem menos de crítica ao ato religioso do que ao ato social. A dama, de conhecimento de todos, pois assim é descrita por este Eu espectador, é "pedantesca", "perversíssima", "esquálida e chagada", tem certa 'jactância quixotesca'. O bom rapaz - hoje uma ossada - o que permite tal inconfidência do Eu espectador, tem "sugestão canina mais submissa", pois “levava na tremente mão nervosa, O livro com que a amante ia ouvir missa!”. Nota-se que, os

impulsos espontâneos. Este é o 'nega-te a ti mesmo' necessário para o verdadeiro progresso moral.”CIRLOT, Juan-Eduardo. Dicionário de Símbolos, Trad. Rubens Eduardo Ferreira Frias. São Paulo: Editora Moares, 1984. Título do original: Diccionario de Símbolos, p. 336.

${ }^{62}$ VERDE, Cesário, op.cit. , p. 57. 
personagens fora da alcova seguem escrupulosamente um tipo de roteiro óbvio, apesar da discrepância entre o que é de foro íntimo e de foro social.

Este foro íntimo, em que o Eu repousa e queima seu olhar, é menos uma 'realidade' empírica do que um vasculhar a si. Há traços nestes escritos daquele 'poeta vidente' que nos fala Rimbaud: "O primeiro objeto de estudo do homem que quer ser poeta e o conhecimento pleno de si próprio; ele sonda sua alma, a inspeciona, a experimenta, apreende-a. A partir do momento em que a conhece, deve cultivá-la!"63 Adiante, o poeta francês dirá aquilo que os poemas deste período de Cesário permitem ler: o desregramento dos sentidos deve ser em pró do encontro consigo mesmo. ${ }^{64}$ Este encontro, vemos, causa a perturbação que nem o sarcasmo final dos poemas é capaz de atenuar: pelo contrário, este sarcasmo só serve enquanto escudo deste Eu em relação aos 'pecados' delatados, ao Outro imoral e suas ações ilícitas. O Eu, desta forma, saí intacto ("Lá nessa eu não caio!), limpo("Quero um banho tomar de água salgada"), inocentado("Todas as noites eu adormecia") e observador crítico do meio("Eu sei um bom rapaz").Mas é, como visto, ou torna-se, tão ou mais fragmentado do que as relações com este Outro.

Em Heroísmos como já citado anteriormente, Helder Macedo lê e dá conotação sexual ao mar e as lágrimas salgadas do choro da amante de Lágrimas. Considera ele que o mar é,"(...) um receptáculo de profanadora dejecção." 65 que ocorre simbolizada pelo escarro.Mas e se a leitura de tal mar fosse também feita através da simbologia não tão estranha à época do mar tanto como origem da vida, e o final da mesma? ${ }^{66}$ Se o inconsciente de Cesário liga tal mar à sexualidade, parece que é o seu consciente artístico que dará um sentido a mais: sendo tal mar 'sublime', que 'nunca dorme', e temido por este Eu por todas as suas características engrandecedoras, este mar constitui-se das figuras mais difíceis para um ponto pacífico. Este mar enquanto Outro se apresenta maior do que qualquer tipo até aqui estudado: ele abarca

\footnotetext{
${ }^{63}$ RINBAUD, Arthur, O Poeta Vidente. In: A estética simbolista. GOMES, Álvaro Cardoso(org.). Trad. Eliane F. Pereira. São Paulo: Cultrix, 1985, p. 47.

64 “O Poeta se faz vidente através de um longo, imenso e racional desregramento de todos os sentidos. Todas as formas de amor, de sofrimento, de loucura; ele procura a si próprio, extrai de si todos os venenos para guardar apenas as quintessências. Inefável tortura, contra a qual necessita de toda a fé, de toda a força sobre-humana, através da qual se torna, dentre todos, o grande enfermo, o grande criminoso, o grande maldito - e o supremo Sábio! - Pois atinge o desconhecido!" Ibidem, p. 48.

${ }^{65}$ MACEDO, Helder,op.cit., p. 72.

66 “Seu sentido simbólico corresponde ao do 'oceano inferior', ao das águas em movimento, agente transitivo e mediador entre o informal (ar, gases) e o formal (terra, sólido), e analogicamente entre a vida e a morte. O mar, os oceanos, são considerados assim como a fonte da vida e o final da mesma. "Voltar ao mar" é como "retornar à mãe', morrer." CIRLOT, Juan- Eduardo, op.cit, p. 372.
} 
todo o Eu, e se separa apenas por um 'barquinho transparente'. Sendo ele a representação da sexualidade, concorda-se com aquela leitura já citada de Helder Macedo e considera-se que a atitude deste Eu com relação ao mar é, de certa maneira a mesma que o Eu vêm mantendo com os tipos femininos (tirante Eu e Ela) até então. São relações problemáticas, quer pelo Eu quer pelo Outro, mas em todos os sentidos, frustrantes. O heroísmo do título seria a atitude de, finalmente o Eu poder desprezar o 'grande mar' que o empurra em direção a tal sexualidade e a tais relações. A natureza de tais relações e a sua própria seriam então, finalmente ultrapassadas à luz de uma atitude sobre-humana.

Considerando-se, no entanto, este mar também como força vital, e por isso quase divina, a atitude torna-se tão ou mais heróica: não se limitaria apenas a resistir à carne, mas enfrentar a morte. $\mathrm{O}$ mar por isso teria 'ruídos dum túmulo disforme'. Mas que morte seria esta? Do 'herói' ou do Eu que finalmente encontra-se à mercê somente de si mesmo, pois velejador solitário que é deste mar-destino, mar-fado, mar-onipotente? Neste caso, em particular, parece ser razoável presumir que de ambos

O confronto entre o Eu e este diferente tipo de Outro, um outro mais temático e por isso mesmo menos 'real', faz com que este poema em sua forma também tenha um cuidado típico de um artista preocupado mais com o 'exterior' do que o 'interior'. O soneto segue à risca aos sonetos clássicos: Há a introdução do tema no primeiro quarteto, o desenvolvimento no segundo, uma contraposição no primeiro terceto e a conclusão do segundo terceto da temática. O ritmo, com acentuação na sexta sílaba e na décima, é o heróico, largamente usado nas epopéias, inclusive na epopéia portuguesa "Os Lusíadas". O uso constante das nasais sonoras, como em: "Eu temo muito o mar, o mar enorme", e das orais constritivas fricativas, como no verso: "Contudo, num barquinho transparente,/ No seu dorso feroz vou blasonar,/ Tufada a vela e n'água quase assente.”, criam o efeito de um vai e vem, ritmado, que soa tanto como as ondas quanto como o vento. Esses rigores formais, rítmicos e sonoros, apesar de constantes neste que foi chamado de engenheiro dos versos, especificamente neste poema é de tal maneira detalhado, que é grande a impressão de que os sentimentos estão cuidadosamente e meticulosamente controlados, e se eles de fato existem, se são o interior deste poema, o são na medida que refletem mais um sentimento que já é impessoal e ganha ares de coletivo. Assim, enquanto pessoal trata dos devaneios sexuais, mas ao passar para o coletivo, pode tratar de outros temas comuns a todos. No caso, o mar enquanto símbolo de pulsão de vida e morte, e conseqüentemente, símbolo de uma transição inescapável, é 
desafiado, heroicamente, por este Eu que o teme, mas não se priva de deixar sua marca pessoal neste mar sem saída.

Cantos da Tristeza, também conhecida n' O Livro de Cesário Verde com o título de Setentrional, ${ }^{67}$ introduz de fato, a dicotomia cidade-campo na poesia de Cesário, meramente esboçada em Eu e Ela, como já demonstrado. Essa dicotomia não se limita apenas às descrições campestres e citadinas e carregá-las de significados. Principalmente ressalta o tom melancólico, já que há dois tempos no poema: o tempo passado, em que a ação é rememorada, e o tempo presente, da narrativa e da elaboração escrita deste rememorar. ${ }^{68} \mathrm{O}$ que se apresenta como o primeiro problema para este $\mathrm{Eu}$ : se o tempo passado é rememorado enquanto sinônimo de felicidade, e tal felicidade necessitava de certas condições, sendo a principal delas a companhia deste Outro, o tempo presente e a ausência deste mesmo Outro, torna aquele que rememora o 'desconcertado' por natureza. O concerto, que em si já demonstra um ser fragmentado, estaria nas mãos de um Outro que, no final das contas, o trairá. O desconcerto, que é o ser rememorando o tal concerto, e já tirado deste mesmo estado, seria a suprema dor da suprema constatação: enquanto ser concertado, sua felicidade era falsa. Enquanto desconcertado, sua tristeza é real, e a rememoração de tal concerto, só causa ainda mais dor, pois deste ponto já não se enxerga sequer a felicidade falsa e sim o concerto malfadado. A questão do tempo verbal é de suprema importância já que delimitar o estado de melancolia é delimitar o Eu enquanto ser saudoso. Delimitar o tempo presente é constatar o motivo do desconcerto.

A primeira quadra introduz a questão da solidão. Apesar da possibilidade de a leitura considerar um monólogo dirigido ao Outro( no caso a 'triste Helena'), é uma rememoração que já se sabe ausente de solidariedade. E esta questão irá se repetir por diversas vezes:

\footnotetext{
${ }^{67}$ É interessante o comentário que Joel Serrão faz em relação a esse acontecimento: "Esta poesia, amputada de 9 quadras que se assinalarão, foi publicada em $O$ Livro de Cesário Verde com o título Setentrional. Acontece que todas as quadras dadas a lume por Silva Pinto - e só essas - haviam sido transcritas num artigo da autoria do organizador de O Livro sob o título de "Cesário Verde" estampado em Diário da Tarde (20-3-1874), ou seja, pouco mais de um mês após a publicação integral dessa poesia no mesmo jornal. Em suma: em 14 de Fevereiro de 1874, Cesário publica o poesia Cantos da Tristeza tal como agora se reproduz; em 20 de Março do mesmo ano, sem qualquer menção a esse respeito, Silva Pinto exemplifica a poesia do seu amigo com as mesmíssimas quadras que 13 anos depois haveriam de aparecer em O Livro." SERRÃO, Joel, in: Cesário Verde - Obra completa, p. 59.

68 "O tempo presente(o tempo da narrativa ou da escrita do poema) é contrastado com o tempo passado(o tempo recordado no poema): o presente é triste, o passado feliz. Dirigindo-se à jovem mulher caracterizada no primeiro verso como uma simples flor campestre("talvez já te esquecesses, ó bonina"), o poeta evoca, no nostálgico monólogo que constitui a narrativa, o tempo feliz em que ela fugiu com ele da "Babel" e viveu só com ele no campo." MACEDO, Helder, op. cit, p. 50.
} 
“Talvez já te não lembres, triste Helena," / "Talvez já te não lembres, pesarosa," / "Talvez já te esquecesses, ó bonina", só para citar as três primeiras quadras. Das vinte e duas quadras (considerando o poema na integra), oito delas tem, literalmente, expressões que demonstram que o Outro já se esqueceu ou não se lembra mais. ${ }^{69}$

Este Outro, nomeado Helena por este Eu reminiscente, é descrita como uma "Mulher como não há nem na Circássia", de "boca purpurina", "cabelos de âmbar, desmanchados". O aspecto da cor do cabelo é repetido na quadra adiante: "Quando eu via, invejoso, mas sem queixas,/ Pousarem borboletas doudejantes/ Nas tuas formosíssimas madeixas,/ Daquela cor das messes lourejantes". Ela acompanha o Eu nesta fuga da Babel, ${ }^{70}$ para o locus amenus que o campo representa, descrito como "terra amena", de "ribeiros remansosos", das "verdes selvas", e no "tempo da colheita dos bons vinhos", do "tempo em que eu vivia nos teus seios/ quando as aves cantando entre as ramagens/ O teu nome diziam nos gorjeios." Este devaneio, em contraposição ao momento presente triste, parece cumprir aquilo que Gaston Bachelard chama de devaneio poético. Tal devaneio nos abre os mais belos do mundo, restaura a confiança do eu no mundo, dando a este mesmo eu uma espécie de conciliação com o não-eu. Em contraposição, ele retira deste Eu a noção do real e mesmo a função do real. ${ }^{71}$

Encarando-se então que tais imagens poéticas são fugas não só da Babel-cidade, mas também desta Babel-homem, em direção à conciliação com o Outro, tem-se o testemunho deste desconcerto duplo: ao mergulhar em si, ele encontra não a saudade de um passado objetivamente real, mas o devaneio que romantiza estas recordações, e ao mesmo tempo, coloca em dúvida o caráter de tais lembranças enquanto 'sinceras'. Como já citado

\footnotetext{
${ }^{69}$ Considerando-se a 'edição' de Silva Pinto, seriam apenas duas quadras que teriam tal expressão, no total de treze.

70 “'Babel', referência imediata à corrupta cidade onde se encontra, é também referência implícita a um 'mal presente' oposto a um 'tempo passado', como nas rimas camonianas de Babel e Sião.’MACEDO, Helder , op. cit., p. 50-51.

71 “O devaneio poético nos dá o mundo dos mundos. O devaneio poético é um devaneio cósmico. É uma abertura para um mundo belo, para mundos belos. Dá ao eu um não-eu que é o bem do eu: o não-eu meu. É esse não-eu meu que encanta o eu do sonhador, é esse não não-eu meu que me permite viver minha confiança de estar no mundo. Em face de um mundo real, pode-se descobrir em si mesmo o ser da inquietação. Somos então jogados no mundo, entregues à inumanidade do mundo, à negatividade do mundo, o mundo é então o nada do humano. As exigências da função do real obrigam-nos a adaptar-nos à realidade, a constituir-nos como uma realidade, a fabricar obras que são realidades. Mas o devaneio, em sua própria essência, não nos liberta da função do real? Se o considerarmos em sua simplicidade, veremos que ele é o testemunho de uma função do irreal, função normal, função útil, que protege o psiquismo humano, à margem de todas as brutalidades de um não-eu hostil, de um não-eu estranho.” BACHELARD, Gaston. A Poética do Devaneio. Trad. Antonio de Paula Danesi. São Paulo: Martins Fontes, 2003. Título original: La Poétique de L'espace, p. 13.
} 
anteriormente, o monólogo insiste que as lembranças deste 'paraíso', e deste tempo-paraíso, já pertencem somente ao narrador de tais imagens, ao iniciar o poema com o seguinte verso que, de uma maneira ou outra, significativamente se repete ao longo do poema:

\section{“Talvez já te não lembres, triste Helena, \\ Dos passeios que dávamos sozinhos, \\ À tardinha, naquela terra amena, \\ No tempo da colheita dos bons vinhos. ${ }^{72}$}

Ou mesmo o primeiro verso do que seria o primeiro quarteto da edição de Silva Pinto:

\section{Talvez já te esquecesses, ó bonina,}

Que viveste no campo só comigo,

Que te osculei a boca purpurina,

E que fui o teu sol e o teu abrigo. ${ }^{73}$

Outro aspecto que chama a atenção é a questão do isolamento e da solidão dos protagonistas deste 'passeio, em que tal solidão ou seu significante se repetirá por seis quartetos. Este isolamento, dentro deste poema, à primeira vista, parece ser apenas circunstancial, dado o caráter da narrativa. Pelo próprio afastamento de ambos e pela nãonecessidade de outros para se sentirem em casa. Mas, este mesmo afastamento também pode significar a falta de testemunhas para se averiguar o caráter do real, e também o testemunho do Eu em relação à sua incapacidade de viver no mundo: o final do poema, em que perambula pela cidade poderia comprovar tal assertiva. Parece, porém, que o problema vai além. $\mathrm{O}$ isolamento e o caráter do que se narra; uma narrativa mágica e romântica (no sentido strictu da palavra)que coloca em dúvida a própria veracidade de tais acontecimentos. Teriam eles acontecidos e rememorados, ou serão apenas delírios solitários de um Eu que foge de si, em direção a este paraíso artificial, para a reconciliação com este Outro? A segunda hipótese parece ser mais coerente com o tom deste poema:

Esqueceste sim, meu sonho querido,

\footnotetext{
${ }^{72}$ VERDE, Cesário, op.cit., p. 59

73 .Ibidem, p. 59.
} 
Que o nosso belo e lúcido passado

Foi um único abraço comprimido,

Foi um beijo, por meses, prolongado. ${ }^{74}$

Levando-se em consideração tal perspectiva, a Helena destes versos pode não ter participado efetivamente de tal passeio, e tudo foi apenas sonho de um solitário Eu a imaginar o ideal dos mundos: Ele, o Outro e o paraíso. Considerando isso, a ironia se estabelece: a mulher "real", objetivamente é impossibilitada do amor, já que está sepultada no "claustro das Fiéis emparedadas", e as recordações que tornam o Amor possível, dependem da mulher "ideal". Este contraste entre o que se recorda, como se recorda e a realidade, tornam o poema e a confissão deste Eu ainda mais melancólico, e a perspectiva do concerto ainda mais distante. Com isso, o último quarteto guarda uma conclusão de tom extremamente pessimista, já que, se houvesse neste mundo empírico a possibilidade do suplicio, do perdão e até do esquecimento deste paraíso artificial, valeria qualquer sacrifício, de corpo e de alma. Mas não há, como este Eu próprio testemunha e conclui:

E, tristíssima Helena, com verdade,

Se pudera na terra achar suplícios,

Eu também me faria gordo frade

E cobriria a carne de cilícios. ${ }^{75}$

O caráter desta conclusão, de que o amor não existe na medida em que poderia reconciliar este Eu consigo mesmo e com o Outro, repete-se de uma forma menos branda e mais cruel em Cinismos. Este poema formado por tercetos e publicado no Diário da Tarde, do Porto, em 12 de Março de 1874, inicia-se com este tema:

Eu hei-de lhe falar lugubremente

Do meu amor enorme e massacrado,

Falar-lhe com a luz e a fé dum crente. ${ }^{76}$

\footnotetext{
${ }^{74}$ Ibidem, p. 62.

75 Ibidem, p. 63.

${ }^{76}$ Ibidem, p. 64.
} 
O Eu deste poema mostra-se determinado, e se utiliza não apenas da veemência, mas de todos os recursos que lhe são permitidos para o Outro comprazer-se de sua confissão. O tom do primeiro terceto, acima registrado, ao comparar-se com um crente, coloca-se na mesma situação de uma testemunha que não precisa de provas materiais para descrever tal amor "enorme e massacrado", e sim apenas desta tal veemência, desta fé cega. No terceto seguinte, utiliza novamente de figuras religiosas, como a "cruz", o Calvário, o Judas, para adjetivar e dramatizar o próprio "peito descarnado", que irá expor à este Outro. Já no terceiro terceto, além de abrir o que chama de 'sacrário', decide usar de argumentos mais lógicos para o convencimento e para capturar a solidariedade deste Outro, tal qual "um velho filósofo lendário". Feita a confissão, leva em consideração inclusive o uso de teatro, através de uma olhada "dum modo tão nervoso". Com todo esse esforço e empreendimento, conseguirá, acredita tal Eu, fazer com que este Outro chore "enternecida" (alias, é neste terceto que o Outro pode ser reconhecida como uma figura feminina, através do pronome pessoal do caso reto, "Ela"), para finalmente, poder rir, vitorioso. Vitorioso? A menos que consideremos que a intenção deste Eu era tão pura e simplesmente a solidariedade deste Outro com sua dor, e a partir desta solidariedade e deste compartilhamento, mostrar-se um ser superior( pois sequer a sua dor lhe causa dor) ${ }^{77}$, o que se nota é um Eu ainda carente de si, e necessitado das lágrimas do Outro. Tal carência se torna visível por esta perda de sensibilidade que Nietzsche exemplifica ao comparar o epicúrio com o cínico:

"O epicúrio utiliza sua cultura superior para se tornar independente das opiniões dominantes; eleva-se acima destas, enquanto o cínico fica apenas na negação. Aquele anda, digamos assim, por caminhos sem vento, bem protegidos, penumbrosos, enquanto acima dele as copas das árvores bramem ao vento, denunciando-lhe a veemência com que o mundo lá fora se move. $\mathrm{O}$ cínico, por outro lado, vagueia nu na ventania, por assim dizer, e se endurece até perder a sensibilidade. ${ }^{78}$

A perda de tal sensibilidade por este Eu fica mais explicita na conclusão, porém, é o modo de como expõe seu discurso, de forma meticulosa, trabalhada e de tom coerente com o conteúdo, que faz com que sua ação final seja ainda mais terrível: não é apenas um ato de

\footnotetext{
77 "O cínico percebe o nexo entre as dores mais numerosas e fortes do homem superiormente cultivado e a profusão de suas necessidades; ele compreende, portanto, que a pletora de opiniões sobre o belo, o conveniente, decoroso, prazeroso, deveria fazer brotarem ricas fontes de gozo, mas também de desprazer."NIETZSCHE, Friedrich, op. cit., p. 172.

${ }^{78}$ Ibidem, p. 172-173.
} 
covardia. É antes um ato de suicídio, pois se apenas pode contar com o Outro para libertar-se deste amor massacrado, ao desprezar este interlocutor, ele fecha as portas para seu concerto. Janet Carter tem conclusão que muito se assemelha, notando que tal 'vingança' transforma-se num ato satânico, a lá Baudelaire, e chama a atenção para a artificialidade deste Eu: "Será que ele sofre? É impossível saber - mas o desejo de fazer sofrer é inegável, e assim temos em vista mais uma mulher que numa situação amorosa com o "eu" é por ela castigada e denegrida, de modo que se estabelece entre o "eu" e o "ela" a distância que está a tornar um motivo repetitivo na poesia de Cesário",79

Em Caprichos ou Responso ${ }^{80}$ a distância entre o Eu e o Outro escamoteia-se pelas figuras que este Eu deseja se tornar para estar mais próximo desta figura feminina. Através da leitura do poema, percebe-se que este tipo feminino é o mesmo de Cantos da Tristeza. Tem, para ser mais preciso, o mesmo obstáculo: é uma mulher 'enclausurada' num mosteiro, dedicando a vida à religião. A impossibilidade desta união faz com que este $\mathrm{Eu}$, no seu desespero romântico, deseje se tornar os objetos que a circundam e que ela utiliza. Daí ele desejar ser "o lenço de Bruxelas/Em que ela esconde as lágrimas singelas", "seus vestidos afogados/ E havia de escutar-lhes os pecados", "ser a lua, lua terna,/E faria que a noute fosse eterna.", "aquelas aves de pilhagem/E cercar-lhe a fronte, em homenagem.”, e outras figuras deste mesmo naipe. A coisificação deste Eu, bem como as imagens que carregam a descrição desta mulher, desde o início não deixam margens a dúvidas da impossibilidade deste encontro: sequer se usará a palavra relacionamento, pois, grosso modo, não existe um contato efetivo entre Eu e o Outro que não seja na imaginação desejosa deste Eu. Haverá, é verdade, uma ocasião em que o pronome nós será utilizado, o que poderia significar a tão desejada união: engano porém, pois é utilizado numa frase derradeira:

\section{Uníssemos, nós dois, as nossas covas, Ò doce castelã das minhas trovas! ${ }^{81}$}

Parece desnecessário ressaltar todos os elementos Românticos deste poema; eles avultam desde o tom sombrio, soturno, até o tema do amor impossível que se realiza apenas na morte. Mesmo na linguagem utilizada e no tipo de metáforas; nota-se que os sentimentos

\footnotetext{
${ }^{79}$ CARTER, Janet, op. cit, p. 125.

${ }^{80}$ Este é o título em O Livro de Cesário Verde, de Silva Pinto.

${ }^{81}$ VERDE, Cesário, op.cit., p. 70.
} 
íntimos prolongam-se pelos objetos e pelo meio, ressoando de forma ainda mais clamorosa e incisiva. Se a alma da mulher está quieta e melancólica, assim também está tudo ao seu redor:

\section{Alta noute, os planetas argentados \\ Deslizam um olhar macio e vago \\ Nos seus olhos de pranto marejados \\ E nas águas mansíssimas do lago. ${ }^{82}$}

Na questão estrutural, bem observa Janet Carter:

“Torna-se imperativo falar nos aspectos estruturais do poema. A relação diádica em questão é entre 'ela' e 'eu'; esta dualidade reflecte-se também na própria estrutura da composição que consiste em doze estrofes, todas rigorosamente divididas em uma quadra e uma copla. Todas as informações a respeito de 'ela' estão contidas nas quadras, ao passo que o 'eu' e as suas atitudes se limitam às coplas; estruturalmente, portanto, o 'eu' mantém-se separado do 'ela'." 83

Tal separação, visual pela forma do poema, concorda com a separação entre Eu e o Outro, entre real e imaginário, entre possível e impossível. A separação entre este Eu e este Outro não é somente a nível objetivo, isto é, uma distância ou um obstáculo que se interponha entre eles. Nota-se, primeiramente, que o olhar deste Eu está todo concentrado nela. Por isso, os verbos das quadras estão no presente, enquanto os verbos das coplas estão no condicional. Esse condicional apenas reafirma aquilo que foi dito nos versos anteriores: se ela chora, este Eu desejaria poder ser o "lenço de Bruxelas/Em que ela esconde as lágrimas singelas." ${ }^{84}$ Se ela se posta ao mar, ele deseja poder ser "o mar e os meus desejos/ Eram ir borrifar-lhe os pés com beijos." ${ }^{, 85}$

O que se tem então, é o caráter do impossível romantizado a última potência. Romantizado, diga-se de passagem, por um Eu que se contenta não só em viver como 'coisa', mas, na impossibilidade de ser tal 'coisa', viver apenas esperando o momento da união que se realizará, segundo este mesmo Eu que vaticina tornar-se um lenço, na cova em que ambos se

\footnotetext{
${ }^{82}$ Ibidem, op.cit, p. 67.

${ }^{83}$ CARTER, Janet, op. cit, p. 130.

${ }^{84}$ VERDE, Cesário, op.cit., p. 67.

${ }^{85}$ Ibidem, p. 69.
} 
encerrarão. Ora, tal Eu se coloca em posição a alguém que considera superior ou à própria ausência de amor-de-si? Quão superior é esta 'cortesã'? A figura feminina em todas as quadras está se lamentando ou chorando. Seria por este Eu, que poderia se considerar então heróico ao desistir de si em pró deste amor impossível? Neste poema, sequer há indício de que este Outro toma conhecimento deste admirador. Por esta perspectiva, tomemos novamente os dados anteriores: o poema tem características ultra-românticas, estruturalmente pode ser comparado aos ofícios religiosos ${ }^{86}$, e estruturalmente delimita Eu e Outro de forma visual e temática; trata do tema amoroso pela perspectiva da impossibilidade, e finalmente, transforma este Eu em um simples objeto deste Outro. Os "dois títulos" ${ }^{\text {" }}$ permitem duas conclusões que não são excludentes: a primeira, sob a perspectiva do título "Caprichos", as coplas revelariam não um desejo real: em face do choro da amada, a atitude 'real' seria oferecer o lenço e não neste se transformar. Ao se transformar em um objeto este Eu are mão de si, e desta maneira, tornaria a união possível. Observando detalhadamente as atitudes deste Outro, sempre choroso e triste, mas principalmente, entregue ao que parece ser uma vida monástica, pelas descrições dos ambientes e constantes rezas, teremos um Outro com menções claramente religiosas. $\mathrm{O}$ capricho à que se refere o título seria então a atitude deste Eu para ter um contato físico com esta mulher impossível. Se o contato que esta mulher se permite são apenas com objetos 'assexuados', este Eu deseja transmorfar-se não para agradar à doce castelã, mas aos seus próprios desejos: "Fosse eu aquelas árvores frondosas/ E prendera-lhe as roupas vaporosas.", numa declaração de forte cunho sexual. Se a mulher abdicou do amor em nome da religião, o único relacionamento possível e a única forma que este Eu pondera para estar ao seu lado é quando ele num objeto se tornar. Assim, realizaria os caprichos de ambos.

Sob a perspectiva do título Responso, nota-se que, durante o ofício, o dogma ou a pregação vem sempre na quadra, o responso nada mais é do que o eco e a afirmação. Mesmo esse 'responso' das coplas soa irônico na medida em que não há um pensar, apenas um responder, neste caso, às lamúrias e aos caprichos desta mulher. Ao estruturar o poema de forma a se confundir com uma reza, deve-se notar o tom de crítica pela impropriedade de tal 'profanação'. Dupla profanação, pois seu intento ao se camuflar dos objetos da amada, é perto dela estar e os caprichos satisfazer. Sob ambas as perspectivas, o que sobressai para esta

\footnotetext{
86 “O título atual, "Responso”, foca igualmente o que está nas coplas, significando 'responso' as palavras rezadas pela congregação, alternando com o coro ou com o padre, num ofício religioso; a parte do coro ou do padre é sempre mais extensa do que aquela da congregação, e assim, no poema o 'responso' é, obviamente, constituído pelas coplas." CARTER, Janet, op. cit., p. 132.

${ }^{87}$ Este poema foi publicado em O Livro de Cesário Verde com o título Responso.
} 
leitura é essa estranha dança entre Eu e Outro: ambos trocam de posição entre ser o sujeito ou objeto, dependendo da perspectiva que se lê. Literalmente, este Eu é o objeto, mas percebe-se que ele só é objeto enquanto tal condição satisfaz suas fantasias. De qualquer forma, este é outro exemplo de impossibilidade de harmonia entre este $\mathrm{Eu}$ e este Outro, enquanto tipo feminino dedicada às 'horas silenciosas' e de forte conotação citadina, entendendo-se tal adjetivo como extensão de tudo aquilo que é obra humana, não-natural. Neste caso específico, a própria religião em si e seus preceitos.

Assim como Caprichos ou Responso, Esplêndida e Arrojos podem ser consideradas como uma unidade ou diferentes perspectivas de uma unidade que se intitula Fantasias do Impossível, título geral para as poesias publicadas no Diário de Notícias, Lisboa, em 22 de Março de $1874 .{ }^{88}$ Enquanto àquela já tratada assume ares de um diálogo com um Outro e seus dogmas, Esplêndida trata de um Eu que, novamente coloca-se em posição inferior à uma mulher, esta porém de ares monárquicos. Sabendo de antemão o tom de crítica de Caprichos, a primeira leitura será também à procura de como este Eu e o Outro são descritos, e qual o caráter de tal relação. Mas antes, para o bem da unidade destas análises, vejamos como o Eu, até então centrado somente em si nos primeiros poemas analisados, alça vôos maiores, e levanta os olhos antes enamorados de si e de suas dores, para um Outro já menos real do que literário. Este caráter de um Outro que se assemelha a um personagem literário e de um Eu que se integra num tipo de escrita reconhecidamente de outro escritor, aumenta o problema da escrita-de-si. Até então, tal escrita limitava-se aos devaneios causados pelas relações problemáticas com o Amor, e assim sendo, o caráter pessoal que se apresenta fica nos limites de uma perspectiva Eu-Outro, diretamente ligados. A partir de Cantos da Tristeza, este binômio Eu-Outro ganha nuances que faz com que se tenha que mudar e considerar outras relações, e outras denominações não tão simplistas: Podem-se resumir as relações e o andar das perspectivas e dos ângulos que as vê através não mais de um binômio, mas de uma relação dialética Eu e Outro, e antitética Eu e o Não-Eu.

Esplêndida insere-se, pela perspectiva intimista, nesta relação dialética. O Outro é descrito como "bela", "como o refulgir dum arrebol/Em sedas multicores", "fidalga e

\footnotetext{
88 À título de curiosidade, a "má fama” de Cesário enquanto escritor começa efetivamente após tal publicação. Ramalho Ortigão pede-lhe publicamente, n'As Farpas, que "seja menos verde e mais cesário", criticando neste o que chama de "baudelairianismo". Teófilo Braga vai mais longe, com uma crítica que já se tornou lendária: "um poeta amante e moderno devia ser trabalhador, forte e digno e não devia rebaixar-se assim”.
} 
soberba", características e descrições que criam uma sensação de realeza emanando deste tipo antes social do que feminino. ${ }^{89}$ Mas não é somente pelo vocabulário escolhido para a representação deste tipo que a áurea de aristocrata se forma. É, neste caso, o ritmo rápido dos decassílabos, acentuado pela escolha de palavras tônicas no começo dos versos como:

\section{Ei-la! Como vai bela! Os esplendores}

$$
\text { (...) }
$$

Deita-se com larguor no azul celeste

$$
\text { (...) }
$$

É fidalga e soberba.As incensadas

$$
\text { (...) }
$$

É clara como os pós à marechala

$$
\text { (...) }
$$

\section{É ducalmente esplêndida! A carrugagem}

O caráter dos versos que se iniciam com tal recurso cria a impressão do tipo arrebatador, que desfila com garbo e força sua beleza e altivez pela Rua do Alecrim: de fato, as cinco primeiras quintilhas são descrições desta mulher 'esplêndida' e de magnetismo impar, suficiente para atrair de tal forma a atenção principalmente do Eu deste poema. Atrai a atenção, porém até certo ponto, pois a ruptura entre o fascínio e a realidade se dá nas comparações impróprias, principalmente dos últimos versos da segunda, da terceira e da quinta quintilha:

Sobem a trote a rua do Alecrim, Velozes como a peste. ${ }^{90}$

\section{Tem a altivez magnética e o bom tom}

Das cortes depravadas. ${ }^{91}$

\footnotetext{
89 “O tratamento irônico da 'esplêndida' mulher do título cria um efeito de distanciamento que a torna na personificação dramática de uma situação social. Ela é um tipo social e não uma pessoa. Isso é imediatamente evidente nas estrofes iniciais em que a 'Esplendida' é evocada através de referências a Versailles, ao Rei-Sol, Dubarry, Montespan e Maintenon - símbolos da ordem social aristocrática do "Ancién Régime'(...)". MACEDO,Helder, op. cit., p. 77.

${ }^{90}$ VERDE, Cesário, op.cit., p. 71.

${ }^{91}$ Ibidem, p. 71.
} 
Ela, de olhos cerrados, a cismar

$$
\text { Atrai como a voragem! }{ }^{92}
$$

O Eu surge literalmente a partir da sétima quintilha pela conjunção e, que se repete nas duas quintilhas seguintes. Este recurso faz com que o este Outro e o Eu tenham uma separação significativa não só em termos sintáticos, mas também em termos qualificativos e quantitativos. O descrever deste tipo feminino e a sujeição psicológica que suas vestes e suas ações permitem ler são tratados nas cinco primeiras quintilhas, enquanto a caracterização do Eu se faz em três:

E eu vou acompanhando-a, corcovado

No trottoir, como um doido, em convulsões,

Febril, de colarinho amarrotado,

Desejando o lugar dos truões,

Sinistro e mal trajado.

E daria, contente e voluntário, A minha independência e o meu porvir,

Para ser, eu poeta solitário,

Para ser, ó princesa sem sorrir,

Teu pobre trintanário.

E aos almoços magníficos do Mata

Preferiria ir, fardado, aí,

Ostentando galões de velha prata,

E de costas voltadas para ti,

Formosa aristocrata! (Estrofes 31-45) ${ }^{93}$

Este eu, como as estrofes acima permitem ler, é um poeta com pouco amor de si ou pouco futuro, pois diz abrir mão de si e de seu futuro em troca de uma servidão representada

\footnotetext{
92 Ibidem, p. 71

${ }^{93}$ Ibidem, p. 72.
} 
por uma farda com galões de prata velha (sequer uma farda nova!). Helder Macedo faz uma análise à luz deste masoquismo, contando a origem de tal termo, e as coincidências tratadas no poema e um episódio real envolvendo o inspirador de tal termo. ${ }^{94} \mathrm{~A}$ atitude deste Eu em sujeitar-se a este Outro ganha novas luzes, literalmente: se antes tal sujeição 'limitava-se' no espaço dos poemas até então lidos a um espaço muito mais 'interno', do próprio sujeito, agora invade as ruas, aos olhos de outros. Se antes tal sujeição dizia-se enquanto homem-mulher, agora diz respeito pessoal-social, e todas as possíveis implicações e leituras que feitas, completam o sentido deste quadro. O que não se pode perder de vista é o tom de crítica que o absurdo da situação cria: crítica à 'esplêndida' do título e o tipo que ela personifica enquanto 'casta social', mas crítica também, a este Eu patético que se põe numa posição de humilhação pelo 'beleza' deste Outro. Não esqueçamos que este Eu apresenta-se como poeta, correndo sem medidas atrás desta 'visão', que representa, no entanto, o padrão de beleza aristocrata, e conseguinte, a Moda. ${ }^{95} \mathrm{O}$ raciocínio é este: se antes o Eu olhava para si e para o Outro de forma direta, e ainda assim o que encontrava era as grandes distâncias, neste momento o Eu perde o olhar de si e não encontra mais o Outro. Nestes poemas, o Eu apresenta-se sem qualquer indício de vaidade, enquanto o Outro inexiste enquanto ser, lembrando mais uma pintura ou uma ode ao absurdo do mundo novo.

Este desconcerto já não é mais de raiz. Já não se trata de relações de níveis psíquicos ou quando objetivas, não há o fator 'social' como um novo obstáculo. Este fator, começa, de fato, neste grupo de poemas que termina com Arrojos. O Eu se coisifica em Caprichos, tornase o personagem poeta-solitário de Esplêndida e novamente, insere-se neste universo citadino em Arrojos, transformando-se agora, num ser aparentemente de potência ilimitada, pois se diz capaz das mais miraculosas ações em troca de outras deste Outro:

Se a minha amada um longo olhar me desse

Dos seus olhos que ferem como espadas,

Eu domaria o mar que enfurece

\footnotetext{
94 “ É na verdade significativo que a fantasia erótica expressa em 'Esplêndida' seja quase idêntica à situação real posta em prática por (Leopold) Sacher-Masoch que conseguiu ser sistematicamente maltratado e humilhado pelo grande amor da sua vida, Fanny Bogdanoff. A relação culminou, depois de Fanny se ter separado do marido, numa degradação social espetacularmente pública: Sacher-Masoch levou-a em longas viagens, pagando todas as despesas, mas fardado e comportando-se como seu lacaio, até que ela se fartou e o 'despediu'." MACEDO,Helder, op. cit, p. 79.

${ }^{95}$ Ver a questão da moda na análise do poema Ironias do desgosto.
} 


\section{E escalaria as nuvens rendilhadas.}

Se ela deixasse, extático e suspenso, Tomar-lhe as mãos mignonnes e aquece-las, Eu com um sopro enorme, um sopro imenso Apagaria o lume das estrelas. ${ }^{96}$

Como se vê, Arrojos assemelha-se ao mesmo tom lamentoso de Caprichos, e também à idéia de um Eu que se colocaria à disposição deste Outro. Por outro lado, a conclusão do poema lembra mais Esplêndida, pela citação de um local citadino, prosaico, 'real' e, assim como dos "almoços magníficos do Mata", este Eu agora fala das "mesas espelhentas do Martinho"97. Enquanto o primeiro era um restaurante da rua do Carmo, em Lisboa, o segundo era um bar-café, na mesma cidade, ambos freqüentado por intelectuais e artistas. Se tanto lá quanto cá há esta referência que se liga aos hábitos deste $\mathrm{Eu}$, e no outro a figura deste Eu enquanto artista é clara, pelo mesmo raciocínio e principalmente por esses versos, que aludem ao ato artístico, a mesma conclusão sobre a 'identidade’ deste Eu pode ser tirada:

\section{Se ela ouvisse os meus cantos moribundos}

E os lamentos das cítaras estranhas.

O que acontece é que este Eu, enquanto canto moribundo acompanhando as tais cítaras estranhas, tem a primeira leitura no trovador e a lira, clássica, e uma leitura já 'moderna', pois o canto já não é límpido e claro, e o instrumento é distinto daquele, oriental, de terras distantes. Considerando-se então os poemas como um conjunto temático, que se explicam por si e em grupo, nota-se que o tom de crítica torna-se ainda mais clara, e é sob esta perspectiva a em que o narrador se propõe a perder a sua identidade de cidadão socialmente respeitável, é a apoteose do erotismo de humilhação associado à cidade, e a antítese do erotismo libertador associado ao campo"98, enquanto Janet Carter apresenta esta visão: "Tal como em Responso, verifica-se em Arrojos a negação do desejo físico, por o desejo ser apresentado como impossível através da dicotomia do real e do fantástico." 99 . Em conjunto, no entanto, pode-se

\footnotetext{
${ }^{96}$ VERDE, Cesário, op.cit., p. 73.

${ }^{97}$ Ibidem, p. 74.

${ }^{98}$ MACEDO, Helder, op. cit. , p. 78.

${ }^{99}$ CARTER, Janet, op. cit., p. 133.
} 
ler uma terceira via: o que se chama de erotismo de humilhação pode ser levado aos outros poemas em consideração principalmente, e talvez apenas assim, pela questão da humilhação pura e simples, real enquanto sentida, baseada, porém em premissas imaginarias. Em Esplêndida é o querer apreender àquela beleza nova, esfuziante mas que se sabe, com licença da figura poética, como uma beleza de exterior vestindo a podridão interior. Em Caprichos a tristeza e a melancolia, e um certo derrotismo do Outro, são atenuados por um Eu que se afigura ainda mais derrotado. Já em Responso, a potência que este Eu diz possuir também de nada lhe vale, já que coloca tal potência subordinada aos atos do Outro.

Ora, se a questão é apreensão da beleza, enquanto poeta ou cantador(ou objeto que sirva a este propósito) este belo deveria fazer com que 'pintasse' belos quadros e não aqueles apresentados. O que concluímos, enfim, é que os três além de iniciar uma nova perspectiva (criticando a velha, obviamente) estilística para a representação desta escrita intimista, apresenta uma visão nova em relação ao Eu e ao Outro, e uma constatação para este Eu: o Outro 'sai' de casa, veste-se como os tempos pedem, adquire vícios e hábitos, e com isso, não mais serve ao intuito primeiro deste $\mathrm{Eu}$, como visto passo à passo neste capítulo, que é encontrar sua unidade perdida num Amor edificante. Este Outro já não serve mais como o espelho, pois adquire 'pernas' com que irá deambular e se transformar, e pior, se esconder atrás desses novos personagens. O cenário, agora, não é mais aquele que o Eu leva dentro de si. Este novo campo de batalha, quer seja o significante citadino quer o campestre, matizarão e tornarão relativa toda e qualquer conclusão que se faça. Mas, torna-se claro até então, que a crise particular, até certo ponto egoísta, ganhará as mesmas proporções que os cenários seguintes. Sai da alcova, vai ás ruas e mostrará toda a sua proporção quanto mais este Eu a si e ao Outro conhecer e reconhecer.

Em Vaidosa, poema publicado n'A Harpa, no 14 de 1874, o Eu apresenta sua situação perante a mulher do título nos dois versos finais do primeiro quarteto. Seu estado é de quem vive "louco de dor e martírio", já que a mulher objeto de seu desejo tanto é "pura como um lírio" quanto "mais fria e insensível que o granito". Nos cinco quartetos que compõem o poema, o quadro psicológico de tal mulher vai sendo descrito sempre em contraponto ao quadro físico. Se por um lado ela tem a beleza, a altivez do modo e o corpo sem defeito, por outro, a frieza já citada, o desdém e a presunção são, numa definição curta e grossa, o que iria por dentro de tal figurino. Esta palavra e esta idéia são literalmente utilizadas no terceiro quarteto: 
Chamam-te a bela imperatriz das fátuas,

A déspota, a fatal, o figurino,

E afirmam que és um puro molde alabastrino,

E não tens coração como as estátuas. ${ }^{100}$

As comparações amplamente utilizadas neste poema, para a caracterização desta mulher, aludem claramente para elementos não só citadinos, mas também modernos. Sendo assim, a conclusão imediata é que a cidade deste tempo age sobre o Eu como um vício, que o prende a esta situação e lentamente o levará ao cemitério. Mas vale algumas perguntas e observações antes de se encerrar de forma tão categórica: o que tal Eu sabe efetivamente sobre tal mulher? Ele sabe ao certo de sua dor e martírio, e sua certeza novamente só se manifestará no último quarteto:

\section{Porém eu sei que tu, que como um ópio}

Me matas, me desvairas e adormeces.

És tão loura e dourada como as messes

E possuis muito amor...muito amor-próprio. ${ }^{101}$

Os quatro quartetos anteriores iniciam-se com verbos na terceira pessoal do plural com valor semântico de indeterminação e, mais importante, são verbos que mostram claramente que as características de tal mulher são contadas e determinadas por outrem e não por este Eu. Como já dito, este declara sua dor, seu desvario, mas nada se pode afirmar de fato, sequer se existe um relacionamento entre ambos. Há inclusive indícios suficientes para dizer que este Eu vê a mulher desejada à distância, de onde vislumbra o "corpo perfeito" e ser ela "loura e dourada", mas somente o último verso do poema põe em dúvida tal distância, já que, se o Eu declara possuir essa mulher "muito amor...muito amor-próprio", pressupõe-se uma proximidade suficiente para conhecer tal adjetivização psicológica, a menos que se trate exatamente daquilo que o título sugere: a mulher, por seu garbo e vestes, extremamente cuidadosa de si, demonstra tal amor-próprio, e mantém sua altivez mesmo quando todos falam dela e a descrevem apenas como um bibelô.

\footnotetext{
${ }^{100}$ VERDE, Cesário, op.cit.., p. 75.

${ }^{101}$ Ibidem, p. 75.
} 
Em contrapartida, pensando nesta mulher enquanto um Outro que aparentemente tem força suficiente para não se abalar pelas circunstâncias (vide o "monótono o teu peito/Como o bater cadente dum relógio.”), o Eu declara seu vício e as conseqüências deste. Repensando novamente a idéia de que tal mulher é a representação da cidade e este $\mathrm{Eu}$, ainda à margem sofre das dores de tal fascínio, e utilizando-se de comparações com o que conhece, que são elementos da natureza, como o lírio e as messes para ressaltar tal beleza, poder-se-ia dizer que este Eu está ou tem memórias vívidas do campo, no que incorreria na já famosa idéia do campo-bom/cidade-ruim. Mas, estando ele à margem, e há a possibilidade de então estar no campo, este não deveria ser "bom" o suficiente para evitar e dissuadi-lo de tal magnetismo nocivo? Deve-se considerar tal hipótese, mas, mesmo ele estando em tal campo, não será absurda a idéia da impossibilidade e da inevitabilidade da cidade invadir, mesmo que não geograficamente, o campo. Tais conjunturas, pensando-se no conjunto da obra de Cesário Verde fazem muito mais sentidos do que apenas se considerando este poema isolado.

Considerando-se porém apenas este poema, e como o Eu é constituído, se deve levar em consideração o fascínio que este Outro causa. Figura feminina, moderna, citadina, quaisquer sejam os adjetivos ainda assim são femininos, e este é o cerne da questão em particular. $\mathrm{O} \mathrm{Eu}$, em atitude de prostração e impotência, vê-se como oposto deste Outro senhor de tanto amor-próprio. Neste caso, o amor-de-si, já demonstrado em poemas anteriores é implícito, pois se este Outro, uma figura feminina de físico tão belo, é tão vaidoso quanto este $\mathrm{Eu}$, que se supõe o favorito entre tantos. Assim, todos neste espaço padecem do mesmo mal: a vaidade de si, alimentada pelo olhar do outro. O ópio é tanto a relação homem-mulher quanto a vaidade, característica que a cidade ressalta mas o campo não pode evitar, pois inerente à condição humana descrita.

Em Flores Venenosas ${ }^{102}$, a relação Eu e Outro tem conotação altamente sensual, e os dez quartetos são ilídios da relação desta mulher, metonimicamente representada pelos cabelos, e este Eu entregue aos prazeres carnais proporcionados:

\footnotetext{
${ }^{102}$ Esclarece Joel Serrão, acerca do título desta poesia, publicada em O Livro de Cesário Verde, edição de Silva Pinto, que o título lá foi: Meridional - Cabelos”, porém no original impresso, o subtítulo de Flores Venenosas: I - Cabelos: "Essa numeração sugere uma série sobre o qual, objectivamente, nada se sabe.É, todavia, plausível que de tal série tivessem feito parte Humorismos de Amor e Ironias do Desgosto, poesias dadas a lume na mesma revista: A Tribuna.” SERRÃO, Joel., op.cit., pág. 76.
} 


\section{Ò vagas de cabelo esparsas longamente}

Que sois o vasto espelho onde eu me vou mirar,

E tendes o cristal dum lago refulgente

E a rude escuridão dum largo e negro mar; ${ }^{103}$

Ó pálida mulher, formosa incomparável,

Que tens o imenso bem de ter cabelos tais, (... $)^{104}$

Neste, o amor-de-si é totalmente calado pelo desejo ao Outro. No primeiro quarteto, o Eu tem como o espelho não um Outro, mas somente a parte física desta mulher, os seus cabelos. T al construção não só ressalta, mas quase que limita a relação no campo físico. Nos quatro primeiros quartetos, o cabelo lembra o mar, e assim é comparado.Tal mar funciona também como um espelho, refletindo, no entanto, não a imagem deste $\mathrm{Eu}$, mas seu estado interior diante deste tradicional símbolo ou arquétipo sensual feminino. Sobre tal imagem, Helder Macedo tece a seguinte analise:

"Nesta complexa imagem, o cabelo da mulher é ao mesmo tempo espelho e mar: tem a intensidade 'cristal, dum lago refulgente' e a 'rude escuridão dum largo e negro mar'. O tema de Narciso, presente na imagem do vasto espelho em que o poeta se vai mirar, revela a ênfase romântica do poema na identidade do próprio poeta. $\mathrm{O}$ espelho reflecte a sua própria turbulência interior e é esta que vai ser expressa na imaginistica da tempestade e do negro abismo associada aos cabelos da amada. As tensões opostas cristalizadas nesta imagem constituem o núcleo do qual deriva todo o poema, que se desenvolve numa série de conceitos barrocos."

Interessante notar a idéia do espelho que reflete não o que vai por fora, mas aquilo que vai por dentro. Diante de uma mulher totalmente objetivada em relação ao poder sensual, já que sua qualidade baseia-se na amplitude e inquietação que causa seus cabelos( "Ó pálida mulher, formosa incomparável,/ Que tens o imenso bem de ter cabelos tais,), o Eu entrega-se, envolto numa correnteza de sensações dispares, consorte dispares são as imagens que tal

\footnotetext{
${ }^{103}$ VERDE, Cesário, op.cit.,p. 76

${ }^{104}$ Ibidem, p. 77

${ }^{105}$ MACEDO, Helder, op.cit., p. 57.
} 
cabelo tem. Assim, a imagem do mar funciona em várias camadas semânticas, e permite entre outras, a idéia do perder-se sem rumo:

E tendes o cristal dum lago refulgente

E a rude escuridão dum largo e negro mar; ${ }^{106}$

No báratro febril da vossa grande treva,

Que tem cintilações e meigos céus de luz. ${ }^{107}$

A constituição deste Eu faz-se por esta relação e as sensações que esta causa. Este Outro é percebido e preenche quase todos os sentidos: o olfato( "Consente que eu aspire esse perfume raro,/Que exalas da cabeça erguida com fulgor,), a audição ("Mas ouço ao ver-te andar melódicos harpejos,/Que fazem mansamente amar e enlanguescer.), a visão (E a tua cabeleira, em ondas, pelas costas,). Quase, pois não há indícios claros de contato físico para que o tato e o paladar sejam preenchidos. Somado a isso, tem-se construções verbais como "deixai-me", "consente", e a ressaltação no penúltimo quarteto, do "ela há-de":

E ela há-de, ela há-de, um dia, em turbilhões insanos(.... $)^{108}$

Esse tipo de relação a distância, esse desejo físico, transforma-se para este Eu em deleite e perdição. Neste poema, novamente a mulher sensual, a "Messalina", torna-se o caminho para a sua perdição, para sua mortes.Entretanto, aqui o Eu sequer esboça qualquer reação contrária, e tudo indica que quer se deixar atingir por essas "vagas". As imagens antitéticas carregam contrastes plenamente aceitos, num deixar-se sem remédio. Não há um Eu irônico, um Eu vaidoso de si, mas apenas um contemplador dessa força natural irresistível. O turbilhão das suas reações refletidas no Outro, no que tem de aspectos claros e escuros, ao contrário de demonstrar confusão demonstra um aspecto totalizante. Este Eu, consciente das forças impossíveis de serem combatidas, internas e externas, mesmo com remos às mãos, mansamente entrega-se. As flores venenosas só a são para aqueles que as cheiram. A suposta

\footnotetext{
${ }^{106}$ VERDE, Cesário, op.cit. p. 76.

${ }^{107}$ Ibidem, p. 76.

${ }^{108}$ Ibidem, p. 78.
} 
emenda nos dois primeiros versos do sétimo quarteto não muda o reflexo deste Eu. ${ }^{109}$ Se lá se pode imaginar uma mulher também entregue ao prazer, o fato de aqui ela ser fria não muda sua imagem arquética. De fato, o que interessa é seu físico e não suas atitudes.

Em Melodias Vulgares, assim como em Eu e Ela, temos um Eu divagando inspirado por elementos campestres. Neste, porém, ao contrário do outro poema, o Eu inspira-se para rememorar acontecimentos lúdicos, enquanto no outro a inspiração serve para olhar o futuro. Se olhar o futuro a partir daquele campo permite aventar a hipótese de que este contém elementos 'esperançosos', no caso deste poema o campo ressaltará o contrário: o Eu, no presente, lamenta sua existência e, ao olhar para o futuro, nos três últimos quartetos declara: "Porém, minha Clarisse, eu peço que não creias/ Que eu ame esta existência e não lhe queira um fim;" " Este campo, ao servir como o espaço onde o Eu em tudo pode ver a imagem da mulher, idealizada e comparada ao mesmo campo, também é usado para o Eu reconstituir a relação que mantinha com esta mulher. Mas quem é esta mulher? Pelas palavras do Eu, ela é "Soberba como um sol, serena como um vôo"111, possuidora de um "olhar moroso e delicado", de "alma ardente e pura"112, "símbolo das santas"113, com "dedos de marfim, polidos e delgados"114 e sua "boa amiga" e "meiga amante" $" 115$. Porém, deste Eu, fisicamente sabemos apenas que tem "um riso mau como o sorrir de Judas" 116 e que está "bem magro e bem curvado"117. Sabemos, no entanto, na décima nona estrofe, que "A aragem a passar parece que me trouxe/ O som da tua voz metálica, sonora,/ E o teu perfume forte, o teu perfume doce."118 , numa aparente contradição de elementos. Se até então está mulher e sua memória só existiam enquanto comparativos da natureza e de um tempo passado, este elemento mecânico possibilita a idéia do moderno, do citadino, do construído pelo homem. ${ }^{119}$ Mas esta mulher é constituída paralela as melodias do título, como se a poetização desta fosse também o ato de poetizar em si. Se esta mulher está em tudo, também em "tudo cintilava o

\footnotetext{
${ }^{109}$ Na edição de Silva Pinto, os versos "Eu sei que não possuis balsâmicos desejos,/ Que és fria e não trilhaste a senda do prazer(...)", estão como: "Eu sei que tu possuis balsâmicos desejos,/E vais na direção constante do querer,"

${ }^{110}$ VERDE, Cesário, op.cit., p, 85.

${ }^{111}$ Ibidem, p.81.

112 Ibidem, p.81.

113 Ibidem, p.82.

114 Ibidem, p.82.

115 Ibidem, p.82.

${ }^{116}$ Ibidem, p.83.

${ }^{117}$ Ibidem, p.83.

${ }^{118}$ Ibidem, p.84

${ }^{119}$ Ibidem, p.84.
} 
límpido poema/ Com ósculos rimado às luzes dos planetas;" ${ }^{120}$. Se ela existe enquanto memória, nesta também reside o “(...) tempo em que eu soltava as notas inspiradas”"121. E a relação é um “(...) bom romance escrito num desterrro" ${ }^{122}$. Mas este Eu reconhece sua culpa pelo fim de tal relação, pois confessa “(...) não ter sabido amar os movimentos/Da estrofe ideal das harmonias mudas". E fica mais evidente a coexistência deste Outro/Poesia no décimo - quarto e no décimo quinto quintetos:

Eu tinha tão impresso o cunho da saudade,

Que as ondas que formei das suas ilusões

Fizeram-me cismar na minha soledade

E as asas ir abrindo às minhas impressões.

Soltei com devoção lembranças inda escravas,

No espaço construí fantásticos castelos,

No tanque debrucei-me em que te debruçavas,

E onde o luar parava os raios amarelos. ${ }^{123}$

Este ato de debruçar-se é um indicativo de que o Eu constituí este Outro não somente pelas suas observações empíricas e comparativas, mas também e, principalmente, por suas impressões e o que elas causam em si. Não é tão diferente de outros Eus até então analisados, pois os amores que parece dedicar a um Outro somente ressaltam o quanto preza a si. Tanto que nos quartetos finais, vaticina:

Mas quero só fugir das coisas e dos seres,

Só quero abandonar a vida triste e má

Na véspera dia em que também morreres,

Morreres de pesar, por eu não viver já! ${ }^{124}$

Assim como na edição de Silva Pinto este não é o último quarteto, lá também o título é outro: Flores Velhas. Alguns versos são também suprimidos, sem grandes problemas para o

\footnotetext{
${ }^{120}$ Ibidem, p.81.

${ }^{121}$ Ibidem, p.82.

122 Ibidem, p.82.

123 Ibidem, p.83.

${ }^{124}$ Ibidem, p.85.
} 
entendimento do poema, mas a inclusão de um quarteto final de fato 'justifica' a mudança do título, pois o foco passa a ser a condição de um casal(as Flores Velhas do título), distantes não tão somente um do outro, mas de sua própria 'terra natural' e de seu tempo, já perdido. ${ }^{125}$ Melodias Vulgares permite olhar um Eu que se constitui pela lembrança totalizante deste Outro, e, apesar do adjetivo vulgar ter conotação de reles, também tem o significado de algo comum. Este é o comum que este $\mathrm{Eu}$, consciente ou penitente de suas escolhas, recebe o sorriso de Judas e é poetizado. Assim, este Eu tanto 'desdenha' deste passado, quanto a constituição que dele se faz, como a querer buscar melodias extraordinárias em outros recantos, temas ou formas.

As flores envelhecidas dramatizam a idéia dos desterrados sedentos de seu passado, que afinal tem também o significado de vida; vida esta que se cristaliza apenas numa lágrima:

E não virás, chorosa, aos rústicos tapetes,

Com lágrimas regar as plantações ruins;

E esperarão por ti, naqueles alegretes,

As dálias a chorar nos braços dos jasmins. ${ }^{126}$

Cadências Tristes tem um dado curioso: publicada pela primeira vez em A Tribuna de Lisboa, é assinada sob o pseudônimo Margarida. ${ }^{127}$ No entanto, não é somente a perspectiva nova criada pela possibilidade de se constituir através da ótica feminina, mas também o diálogo com o poeta João de Deus que criam novos horizontes. Acontece uma inversão não só de gênero, mas de valores. O Eu constituindo-se pela visão feminina diz que “(...)gosta de te ouvir falar timidamente/ Num beijo, num olhar, num plácido ideal"128 e que gosta "(....)de te ver contemplativo e crente"129. O poeta João também tem o "cândido lirismo",130, de rosto que

\footnotetext{
125 “(...)entendidos como pólos de uma articulação contrastiva intrínseca ao poema, cidade e campo passam a representar dois níveis diferentes de percepção, convergindo para caracterizar um aqui e agora através de um além e então.” MACEDO, Helder., Cesário Verde, o bucolista do realismo. Colóquio Letras, no. 93. Setembro de 1986, p.21.

${ }^{126}$ VERDE, Cesário, op.cit., p. 90.

127 “ Publicada pela primeira vê, em A Tribuna, Lisboa, n 52, 27 de Dezembro de 1874, sob o pseudônimo Margarida. Vinte e um anos depois, em 1895 e, portanto, postumamente, foi republicada na Revista Portuguesa, da direcção de Joaquim de Araújo, n4, Março, a pp. 148-149, onde apareceu subscrita por Cesário Verde, e acompanhada da seguinte nota da redação; "O simples nome de Margarida constituía a assinatura destes formosas versos, quando Cesário Verde os enviou a João de Deus”SERRÃO, Joel, op.cit., p. 91

${ }^{128}$ VERDE, Cesário, op.cit, p.91.

${ }^{129}$ Ibidem, p.91.

${ }^{130}$ Ibidem, p.91.
} 
“exprime uma serenidade" $" 131$, mas é no terceiro quinteto que é apresentado de todo:

O enleio, a simpatia e todo a comoção

Tu mostras no sorriso ascético e perfeito;

E tens o edificante e doce amor cristão,

Num trono de bondade, a iluminar-me o peito,

Que é a toda a melodia e toda comoção! $!^{132}$

Mas o quinteto seguinte limita o poeta à "poeta da mulher" e pede: "Atende, escuta, pensa,/ Já que és o nosso irmão, já que és o nosso mestre". ${ }^{133}$ Ora, se o Eu se constitui enquanto uma figura feminina, a irmandade só se dá assim, e somente nesta condição este Eu considera o poeta seu mestre. Considerando como se constituiu até então, faz sentido: o Outro, enquanto figura feminina, ressaltava seu amor próprio ou a estranheza das relações. Neste caso, há uma irmandade, pois este Outro se caracteriza pela figura de um poeta que entende o universo feminino e o canta. É irônico pensar que, apenas sob o nome de Margarida, uma máscara que Cesário usa para constituir este poema, e subseqüentemente este Eu, há harmonia entre o Eu e o Outro. Parece que tal harmonia só pode existir sob artífices literários, e qualquer movimento em direção à razão poderia destruí-lo. Por isso, o Eu declara no último quinteto:

E ó meigo visionário, ó meu devaneador,

O sentimentalismo há-de mudar de fases;

Mas só quando morrer a derradeira flor

É que não hão-de ler-se os versos que tu fazes;

ó bom João de deus, ó meu devaneador!"134

Saindo da razão, o devaneio levaria este Eu para o lugar do poema, de sonora harmonia, em que o final dos primeiros versos tem eco no final dos últimos versos de todos os quintetos. Mas, mesmo dentro de aparente coesão, este Eu ainda cisma: "E fico descansada, à

\footnotetext{
${ }^{131}$ Ibidem, p.91.

132 Ibidem, p.91

${ }^{133}$ Ibidem, p.91.

${ }^{134}$ Ibidem, p.92.
} 
noute, quando cismo" 135 e é este mesmo Eu que usa do imperativo para dizer: "Atende, escuta, pensa". Pensar, no que? Responde este Eu: "Que ela, ou doente sempre ou na convalescença,/É como a flor de estufa em solidão silvestre,/Ao tempo abandonada!"136 . No que se vê um elemento diferente: se o Eu é uma figura feminina, porque não usar o nós ao falar da mulher? Por que, assim como nos poemas posteriores, a mulher vista com olhar piedoso, e tal olhar envolve uma irmandade também, está deslocada não só no tempo, mas também no espaço. Isso acontecia com o Eu em outras ocasiões, mas não nesta, pois este $\mathrm{Eu}$ existe apenas enquanto representação de um drama, enquanto uma voz que se dedica a louvar aquilo exatamente que não é e não tem. As cadências se justificariam pelo movimento rítmico e sonoro do poema e a tristeza poderia estar no fato de que, somente pela máscara, este Eu poderia situar-se num universo harmônico. Este devaneio funcionaria assim como funciona o campo do poema anteriormente analisado. Devaneio que tem fim pela própria incapacidade deste Eu de se situar neste tempo e neste espaço, pois as palavras do poeta são dirigidas ou deveriam, a outrem. Para este Eu, as palavras já não são mais inocentes, mas resta ainda dentro dele algo que permite seu descanso, quando "tentam proscrever a sensibilidade,/E querem denegrir o cândido lirismo". ${ }^{137}$

Em Deslumbramentos somos informados logo de início quem será o interlocutor deste $\mathrm{Eu}:$

Milady, é perigoso contemplá-la

Quando passa aromática e normal,

Com seu tipo tão nobre e tão de sala,

Com seus gestos de neve e de metal. ${ }^{138}$

Bem escreveu Helder Macedo ao analisar esta mulher:

"No contexto, o uso da palavra 'normal' tem um óbvio propósito de choque. A perigosa senhora perfumada, cujos 'gestos de neve e de metal' são uma combinação de qualidades frigidamente desumanas, é reconhecidamente excepcional, em tipo e

\footnotetext{
${ }^{135}$ Ibidem, p.91.

136 Ibidem, p. 91.

${ }^{137}$ Para uma análise mais rica e pormenoriza, apesar de diferenças de foco, ver CARTER, Janet, Cadências Tristes.

${ }^{138}$ Ibidem, p. 93.
} 
classe, como um produto das convenções mundanas, ' com seu tipo tão nobre e tão de sala'.E no entanto, este ser artificial é descrito como 'normal'.A implicação é que a 'Milady', como produto típico da cidade, representa a norma que é a cidade"139

Se até então a idéia da cidade ainda poderia ser tímida, aqui, os elementos são mais claros: a própria futilidade da milady em impor toilletes complicadas, seu porte, "como a Moda supérflua e feminina", e a idéia dos povos "humilhados". Mas qual a atitude deste Eu? Sente atraído, como a "um tesoiro" ${ }^{140}$, estonteado e fascinado, assombrado:

Em si tudo me atrai como um tesoiro:

O seu ar pensativo e senhoril,

A sua voz que tem um timbre de oiro

E o seu nevado e lúcido perfil!

Ah, como me estonteia e me fascina...

Eé, na graça distinta do seu porte,

Como a Moda supérflua e feminina,

E tão alta e serena como a Morte!... ${ }^{141}$

O Eu neste ponto, aparenta já não simplesmente olhar para si. A Milady não vive num recanto da memória ou é um objeto distante de pura contemplação. Este Eu tem o 'privilégio' de estar perto dela, e parece à ela dedicar toda a sua afeição. Mas esta Milady não é tão somente um tipo social, apesar do "Britânica" e outras imagens que aludem as realezas. Talvez mesmo com uma implicação crítica à sociedade ${ }^{142}$, ainda seja a relação homem-mulher o cerne desta questão. Cabral Martins, ao analisar Deslumbramentos, escreve: “Aquilo que há para explicar na situação dramática que o poema figura não é a metáfora da humilhação do povo explorado pela classe possidente, mas a idolatria que aquela personagem devota àquela

\footnotetext{
${ }^{139}$ MACEDO, Helder, Nós, p. 81.

${ }^{140}$ VERDE, Cesário, op.cit, p. 93.

${ }^{141}$ Ibidem, p. 93.

142 "A oligarquia portuguesa da segunda metade do século XIX via a Inglaterra como o símbolo do progresso industrial e do triunfo de todos os ideais burgueses representados pela cidade. A humilhação do narrador perante a "Milady" inglesa pode ser entendida, assim, como um paralelo individual dos sentimentos de inferioridade da burguesia portuguesa em relação às raças 'civilizadas' do Norte, um tema que vai ser desenvolvido mais tarde pela poesia de Cesário.” MACEDO, Helder, Nós, p. 83.
} 
que o despreza.É um fascínio que se trata, mas nem o das moscas pela luz nem o dos pobres pelos ricos. Muito simplesmente o do homem pela mulher." ${ }^{143} \mathrm{O}$ Eu desentende-se desse fascínio ao beijar às mãos dessa mulher fria e receber menos do que gostaria:

Pois bem. Conserve o gelo por esposo,

E mostre, se eu beijar-lhe as brancas mãos,

O modo diplomático e orgulhoso

Que Ana de Áustria mostrava aos cortesãos. ${ }^{144}$

Se este Eu se configura neste caso como contraponto do gelo, e tem este como rival, as possíveis implicações sociais, fora, portanto, deste 'universo-poema' ficam menos importante do que saber que este $\mathrm{Eu}$, ainda demonstra ser o orgulho, o amor-de-si, maior do que qualquer visão simplesmente ideológica. Sua visão ainda é muito pessoal, apesar da caracterização desta mulher buscar elementos claramente sociais e históricos. O diálogo que trama, no entanto não é com esse momento histórico ou com uma posição ideológico-social, melhor dizendo: dialoga sim com esses elementos, mas num nível ainda inferior aos chamados de sua consciência centrada em si. Ele ainda se vê em estado bruto, e ainda assim se porta: "Que eu procuro fundir na minha chama/ Seu ermo coração, como a um brilhante." ${ }^{\text {"45 }} \mathrm{O}$ comportamento desta mulher o irrita de tal forma que ele passa a desejar sua 'queda'. Mas, impotente por sua devoção, nada faz, apenas aguarda e deseja ser observador deste fato:

E um dia, ó flor do Luxo, nas estradas,

Sob o cetim do Azul e as andorinhas,

Eu hei-de ver errar, alucinadas,

E arrastando farrapos - as rainhas! ${ }^{146}$

Colocando em maiúsculos elementos modernos, e conseqüentemente citadinos, como a Moda, a Fama e o Luxo, pode-se pensar tanto na idéia do social, quanto na idéia do histórico, porém a atitude deste Eu perante a tais fatos não são de crítica direta, mas elementos usados para adjetivizar este Outro. O uso do coloquismo "Pois bem", ressalta a idéia de que,

\footnotetext{
${ }^{143}$ MARTINS, Cabral. Cesário Verde ou a Transformação do Mundo. $1^{\circ}$ Edição. (Coleção Estudos da Cultura Portuguesa). Lisboa: Editorial Comunicação, 1988,p. 47.

${ }^{144}$ VERDE, Cesário, op.cit, p.94.

145 Ibidem, p.94.

146 Ibidem, p.94.
} 
este $\mathrm{Eu}$, menos preocupado com condições entre classes ou histórico, preocupa-se sim com seu orgulho ferido, com seu amor mal correspondido. E o uso da palavra "rainhas" em minúscula, em contraponto ao uso das citadas em maiúsculas, parece demonstrar exatamente que a mulher amada não é da realeza ou de uma classe superior, e sim sua atitude altiva e fria é semelhante à de rainhas. Este Eu ainda demorará um pouco para olhar de fato, fora de si.

Humorismos de Amor ${ }^{147}$ é similar em conteúdo ao poema anterior, e também neste vemos um Eu quase juvenil, desejando a mulher amada que se mostra fria e distante.O desejo limita sua realização ao olhar, ao observar. Esta mulher também é "fleumática", tem "longa e plácida estatura", "Expõe a majestade austera dos invernos". A diferença é que o diálogo que mantém são com escritores, com o universo literário, a saber: Balzac e Charles Baudelaire. Mas não é um diálogo exatamente à nível filosófico ou ideológico, mas tão somente o imaginético feminino que esses dois autores criaram. De Balzac, reclama este ter criado as “carnações redondas', em clara referência ao que se intitulou 'balzaquianas', mulheres acima de trinta anos, já um tanto distante da 'flor da idade' e do físico longelíneo. De Baudelaire, a já citada "dame sans merci"148. "Frígida", escreve Cabral Martins

"é um texto, sem dúvidas, afim de Deslumbramentos, e com ele pode ser comparado. Assim, no primeiro verso dos dois poemas, a 'senhora inglesa' é simétrica da 'Milady'; ambas as figuras são evocadas a caminhar; a 'majestade austera' de Frígida é idêntica à 'real solenidade' da 'Milady'; os adjetivos 'fleumática, irritante' de uma ecoam os 'dramática, cortante' da outra; o motivo do beijo desejado é próximo, em Frígida no 'pulso', em Deslumbramentos nas 'brandas mãos', mais diplomático; a 'lucidez' do rosto de uma dá na segunda um 'lúcido perfil'. Até a Morte as identifica: a Frígida é o 'sossegado espectro angélico da Morte', a 'Milady’ é ‘tão alta e serena como a Morte'. Não há dúvida de que o tipo de mulher, de que a 'personagem' é a mesma nos dois poemas."149

O crítico também aponta uma diferença essencial: em Frígida o olhar é carregado de

\footnotetext{
${ }^{147}$ Em O Livro de Cesário Verde: Frígida.

${ }^{148}$ Nota de Helder Macedo, p. 86, sobre Baudelaire: "É natural que Cesário tenha tido em mente o poema de Baudelaire 'Les Metamorphoses du Vampire', onde se encontram muitas imagens semelhantes às de Frpigida', v.g. a serpente, o Sol, a Lua, as estrelas, as noites de Inverno" .

${ }^{149}$ MARTINS, Cabral, op. cit, p. 46.
} 
ironia, o que distancia o Eu deste Outro ${ }^{150}$ :"Mas nunca a fitarei duma maneira franca." ${ }^{151}$ Ora, se a realização do poema e a constituição do Eu e da relação com o Outro está toda centrada no olhar, esta frase coloca em questão a própria ‘devoção' deste Eu. Porém, é de questionar se a diferença não se dilui ao pensar no primeiro quarteto de Deslumbramentos, quando o Eu anuncia: “"Milady, é perigoso contemplá-la”. Este parece um Eu ciente, e consciente, das implicações deste olhar, diferentemente de Responso, por exemplo. Os dois poemas têm uma temática e semelhanças na discrição desta mulher, e semelhança de como o Eu, apesar da devoção, mantêm-se distanciado, ainda estranho ao Outro.

A construção de Ironias do Desgosto é feita por um diálogo que apresenta duas curiosidades: o fato de, das oito quadras do poema, só três, as últimas, são a "fala" do sujeito poético. As cinco primeiras são a fala de um sujeito, uma mulher, que faz considerações acerca desse "eu"; a outra curiosidade é esse diálogo ser construído de forma muito próxima ao que se convencionou chamar de discurso direto em uma narrativa: "“'Onde é que te nasceu” - dizia-me ela às vezes -". Esse “dizia-me ela...” introduz o outro no discurso como uma personagem. No discurso direto, o narrador deixa que a personagem fale com "a sua própria voz".Isso significa deixar que a personagem seja caracterizada pelo seu próprio discurso: é na intencionalidade da sua fala que ela se revelará. No entanto, quase que toda fala desse outro é usada para passar uma determinada imagem do sujeito poético, ou melhor, é a imagem que o sujeito projeta no outro. Deve ser salientado o caráter oral das falas, tal oralidade nos permite criar uma maior familiaridade com o que é dito, dá-nos a impressão de uma conversa cotidiana que pode ter sido repetida várias vezes. Jacinto do P. Coelho afirma que "Cesário desenvolveu uma ação paralela na linguagem poética, ductilizando-a, aproximando-a da vida, tornando-a apta a sugerir as impressões complexas e subtis..." ${ }^{152}$, essa aproximação da linguagem com a vida cotidiana desenha um quadro tão familiar que se torna íntimo. Não estamos distantes observando uma conversa inteligível sobre a fugacidade da vida e a deterioração da beleza, estamos, os leitores, dentro de uma conversa de um homem com uma dama.Estamos com o olhar voltado para a intimidade desses "seres".

\footnotetext{
150 "Frígida constrói um 'eu’ enunciador distanciado em relação a si próprio, que não coincide com aquilo que diz, que para si reserva um irônico retiro de consciência que o preserva da perigosa cintilação da 'gélida mulher bizarramente estranha', da 'jibóia': eis o que pode tornar claro o verso célebre 'Pudesse-me eu prostrar, num meditado impulso"”. Ibidem, p. 46.

${ }^{151}$ VERDE, Cesário, op.cit. p. 95.

${ }^{152}$ COELHO, Jacinto do Prado. "Cesário Verde escritor”, in Problemática da História Literária. 2ed. Lisboa: Ática, 1961, p. 195.
} 
Voltemos à afirmação feita um pouco acima, sobre o caráter narrativo do poema em questão. Podemos supor que o sujeito poético ao dar a voz ao outro teria a intenção de criar uma ação, contar-nos uma história. Porém, se levássemos tal afirmação ao pé da letra, negaríamos o próprio caráter da lírica. Se Cesário se serve de uma técnica narrativa para que o outro fale por si só, isso brota mais da curiosidade do sujeito de olhar dentro da intimidade alheia, de captar nas imagens desse outro um pouco do seu próprio "oculto", do que a tentativa de se contar uma história. Sobre esse "olhar", Bachelard diz que: "A vontade de olhar para o interior das coisas torna a visão aguçada, a visão penetrante. Ela detecta a falha, a fenda, a fissura pela qual se pode violar o segredo das coisas ocultas. A partir dessa vontade de olhar para o interior das coisas, de olhar o que não se vê, o que não se deve ver, formam-se estranhos devaneios tensos, devaneios que formam um vinco entre as sobrancelhas" ${ }^{\prime 153}$.

Deve-se, ainda mais uma vez, prestar atenção no que o "dizia-me ela às vezes" pode ajudar nesse olhar que tenta buscar o "oculto". O verbo dizer está conjugado no pretérito imperfeito, o que dá a idéia de continuidade de uma ação no passado. Logo, seria improvável, a não ser que se limitasse a umas poucas sentenças, um sujeito repetir um discurso exatamente com as mesmas palavras. Dito isso, podemos concluir que a voz dada a esse outro é uma ilusão, pois quem a reproduz, o sujeito poético (é ele quem introduz a fala da mulher no corpo do poema e é ele quem toma voz na réplica: “e eu só lhe respondia...”), só o poderia fazer se repassasse essa fala na memória até fixá-la. Fazer isso seria, de certa forma, editar o discurso do outro, ou melhor, desenvolver o discurso do outro de acordo com a relação desse "eu" com o "outro".

A memória produziria um discurso ideal, discurso que resumiria o olhar "mais importante" que o outro dedica a esse "eu". Há na escrita intimista alguns recursos que pretendem mostrar o "eu", o sujeito, sua complexidade e psicologia de forma que o leitor tenha a sensação de impessoalidade, para isso o poeta pode usar de "artimanhas" que distanciem o escrito do sujeito que escreve (aqui não se trata do homem real). Um recurso que pode ser utilizado é a terceira pessoa, o "ele”. O recurso que Cesário emprega é mais ou menos parecido. Ele usa a voz do outro para que o "olhar" para si mesmo corresponda a uma objetividade não corrompida por sua subjetividade. No entanto, é um recurso e a memória

\footnotetext{
${ }^{153}$ BACHELARD, Gaston. A Terra e os Devaneios do Repouso. 2ed. São Paulo: Martins Fontes, 2003, p.07.
} 
trabalhada do discurso desse outro nos impede de achar que sua "fala" não está carregada da fala do próprio sujeito sobre si mesmo e de como o sujeito enxerga esse outro. Feitas essas considerações, podemos, afinal, no poema procurar quais são as imagens desse sujeito.

Na primeira estrofe, conhecemos a consciência que esse sujeito tem da morte, "Onde é que te nasceu.../ O horror calado e triste às coisas sepulcrais?", por essa mulher. O fato de esses dois primeiros versos terem sido construídos por uma pergunta, não nos deixa dúvida do "horror às coisas sepulcrais" que testa o sujeito poético, pois a imagem se constrói na própria incompreensão do outro àquilo que parece ser particular do sujeito. Podemos observar, pela disposição das rimas que há uma oposição formal quando tratados o "eu" e o "outro": o cruzamento das rimas "vezes/ franceses" e "sepulcrais/ sais" mostram um sujeito alternandose com o "objeto". O par "vezes/ franceses" opõe a fala do sujeito à vitalidade, a "verve”, que se atribui aos franceses. O "sepulcrais" que caracteriza o sujeito se opõe duramente à sensualidade, ou ao apelo feminino desse "outro", representado nos "sais". Nessas rimas percebemos alguns pares antitéticos o "eu/ outro", "vitalidade/ tédio e consciência da morte" e "virilidade/ feminilidade".

Deveríamos supor, por acaso, que a consciência da morte é já uma predisposição para o tédio, responsável pelo olhar "moroso e persistente" desse sujeito? Na segunda estrofe, a imagem do íntimo mais reveladora é "as fundas abstrações". Joel Serrão ${ }^{154}$, sobre o tédio, escreveu que o ser humano é o único animal capaz de sentir aborrecimento. Os bichos não o sentem, pois suas vidas se processam pelos interesses imediatos, comem se sentem fome, bebem se sentem sede e etc. Quando não estão presos a esse interesses, os bichos dormem. O humano sente sua relação com o tempo de modo muito diferente, para que não percebamos a passagem do tempo é preciso preenchê-lo, é preciso não senti-lo, pois necessariamente não dormimos quando nossos interesses imediatos já foram resolvidos. Esse meio termo, entre o que fazemos para satisfazer nossas vontades imediatas e o sono, traz algumas "abstrações". Se essas abstrações forem "fundas", pode-se ter uma sensação de que o tempo não passa, que todo o tempo é um tempo único. Simplesmente se espera o tempo final, a morte.

${ }^{154}$ SERRÃO, Joel. Temas Oitocentistas. Vol.II. Lisboa: Portugália Editora, 1962, p.157 - 169. 
Joel Serrão define o tédio nestes termos: "consiste precisamente na consciência de que a navegação se faz sem norte e de que é impossível qualquer orientação." ${ }^{~} 155$, logo não é a consciência da morte que encadeia o tédio mas, sim, seu contrário. Se o tédio é o sentimento da impossibilidade de orientação, o sujeito poético não poderia ser orientado pelo "abalo feminil" das "expansões" dessa mulher. Ora, se isso fosse possível ao sujeito, o tédio não estaria tão enraizado no seu "ser". Vemos, novamente, a rima do $2^{\circ}$ com o $4^{\circ}$ verso colocar o sujeito e o outro em planos diferentes: "abstrações/ expansões".

A morte e o tédio revelados no olhar "moroso e persistente" do sujeito poético tornam seu aspecto senil, não fisicamente, mas por um certo cinismo nas suas maneiras "Há quem te julgue um velho. O teu sorriso é falso; / Mas quando tentas rir parece então, meu bem,/ Que estão edificando um negro cadafalso/ E ou vai alguém morrer ou vão matar alguém!", além desse cinismo há a morbidez de quem ri, mas ri com "fel no peito", como se afirma na estrofe anterior. Logo, não há um sorriso sincero, despojado do tédio, do tempo que passa e da morte.

A "fala" da mulher, nessas estrofes que comentamos, é toda uma tentativa de construir uma concepção do sujeito poético, como já foi afirmado, por pares antitéticos. Na quarta e quinta estrofes, a relação do sujeito com o outro ainda é construída por antíteses, mas, agora, o outro fala de "si mesma" e nesse falar de si mesma ela também fala do sujeito poético, pois se antes a imagem do sujeito era sua antítese, agora ao se caracterizar ela dá a medida daquilo que o sujeito não é.

"Eu vim - não sabes tu? - para gozar em Maio, / No campo, a quietação banhada de prazer!", esses versos da quarta estrofe mostram uma oposição que, segundo a crítica, é constante e substancial na obra de Cesário, a cidade e o campo. Já foi afirmado que o "dar voz ao outro", nesse poema, parece muito mais um recurso para garantir a objetividade ao tratar de si do que a tentativa de se construir a imagem desse outro. Logo, se o riso do sujeito poético é "falso", a imagem diametralmente oposta é a da mulher que encontra prazer no campo. Podemos pensar, porém, que no outro a felicidade existe, no campo o silêncio não é o mesmo que testa o sujeito poético. O silêncio do sujeito é aquele "horror triste às coisas sepulcrais", o do outro é a "quietude banhada de prazer". Portanto, no outro e, por conseguinte, no campo, o sujeito pode testar um certo devaneio de felicidade: "Os primeiros

${ }^{155}$ Ibidem, pp. $161-162$. 
devaneios ligados à imagem íntima do objeto são devaneios de felicidade. Toda intimidade objetiva seguida em um devaneio natural é um germe de felicidade ${ }^{\text {156 }}$.

Porém, é só o "devaneio" desse sujeito poético que traz esse "germe de felicidade", pois uma rápida visão do campo mostrada pelos olhos do outro, serve apenas como uma maneira de ser no mundo, parece momentaneamente um atenuante para esse sujeito que é "descorado", pálido, sem cor e sem vida. No $3^{\circ}$ verso da quarta estrofe e no $1^{\circ}$ da quinta, o outro do discurso interpela esse sujeito apelando para sua visão: "Não vês, ó descorado,..." e “Não vês a campina toda embalsamada/ E como nos alegra em cada nova flor?”. Esse apelo à visão resulta inútil, visto que a visão de uma nova flor só aumenta, no olhar desse sujeito, "as fundas abstrações". É na vida que nasce e que se deteriora que ele tem sua visão aguçada, a visão da flor não o comove porque amplia a visão da fugacidade da vida e da beleza. Mais adiante, a visão do cabelo escuro dessa mulher causa a visão do cabelo branco, sinal da velhice e da degradação física $O$ que sobra desse possível refúgio, desse atenuante do sentimento de tédio é uma "fronte consternada/ Um não-sei-quê tocante e enternecedor", isto é, uma comoção diante da beleza perdida (ou que logo irá se perder).

Nas três estrofes finais o sujeito toma a palavra no discurso. Na primeira, esboça-se, enfim, uma explicação para sua maneira de ser no mundo. Essa "explicação" não é dada por exemplos que partem do sujeito poético, ele usa o corpo do outro para mostrar essa passagem do tempo e suas conseqüências. Todo o apelo no qual o outro se empenhara para tirar essa gravidade do sujeito se mostra inútil, pois “... Conforme/ Tu vibras os cristais da boca musical, / Vai-nos minando o tempo, o tempo - o cancro enorme/ Que te há-de corromper o corpo de vestal.”. O processo de construção das imagens a partir do outro permanece, é esse "eu" entediado que sente, resultante da passagem do tempo, o aniquilamento do ser, muito mais psicologicamente nele e mais fisicamente na mulher. Mas ele não poupa seu objeto de desejo, no que talvez mais a atinja (seu "corpo de vestal"), de mostrar a inexorabilidade do tempo.

Joel Serrão distingue duas maneiras de se sentir tédio: “...a experiência pessoal de que algo - uma coisa, um indivíduo, uma situação - me aborrece não é idêntica à experiência de

${ }^{156}$ BACHELARD, Gaston. Op. cit., p. 14. 
eu mesmo estar aborrecido"157. Ele chama o aborrecer-se com algo de "tédio objetivo", o "eu mesmo estar aborrecido" de tédio subjetivo. Mais adiante, ele afirma sobre o tédio subjetivo que pode "significar ou o preâmbulo de um novo processus psíquico, motivado por novos interesses, ou a estagnação, anormalmente prolongada, ou definitiva, de uma mente em crise. Crise essa que consiste na impossibilidade de equacionar os dados oriundos do conhecimento da condição humana com fins valiosos, sem os quais a vida, em vez de processar-se, estagna." ${ }^{158}$. No advérbio "calmamente" do verso "E eu calmamente sei, na dor que me amortalha", deixa-nos a sensação que, embora a dor desse sujeito o mortifique, ele a recebe e aceita sem alarmes ou surpresas.

Devemos notar que essa calma do sujeito é diferente da "quietação" no campo. A calma do eu-lírico é a lassidão do sujeito aborrecido, lassidão que lembra o spleen, sentimento muito característico do fim do século XIX, mas que é tipicamente do sujeito imerso na urbs. Até essa estrofe não há uma referência do sujeito à cidade, temos a visão que esse sujeito é citadino quando a mulher chama sua atenção para "cada nova flor", pois o sujeito é constituído pela antítese do outro. Esse argumento não seria suficiente se o próprio sujeito também não fizesse, por ele mesmo, referência, ou uma simples menção,ao seu modo de ser no mundo urbano. A menção a "Rabagas" traz a imagem dos teatros e de uma vida cultural citadina, a menção ao "gás" lembra a vida noturna na cidade ( a iluminação à gás).

É claro que o "gás" não tem em "Ironias do Desgosto" a mesma importância que vai adquirir em "O Sentimento dum Ocidental" e outros poemas, mas a menção se torna importante porque é ao "gás" que a cabecinha dessa mulher "alvejará". Isto é, a imagem do campo gera a vida, a "nova flor", a imagem da cidade está associada à morte e a degradação, em suma, à decadência.

$\mathrm{Na}$ derradeira estrofe, diferentemente do eu-lírico baudelairiano ${ }^{159}$, que ao mostrar uma carcaça à mulher amada também reflete sobre a fugacidade da vida e, para se exemplificar mais claramente, lembra a essa mulher que seu corpo um dia vai ter a beleza daquela carcaça, o sujeito poético cesárico lembra à sua amada da fugacidade da vida e

\footnotetext{
${ }^{157}$ SERRÃO, Joel. Op. cit., p. 164.

158 Ibidem, p. $164-5$.

${ }^{159}$ Ver o poema "Uma Carniça" in: BAUDELAIRE, Charles. Flores do mal. São Paulo: Martin Claret, 2003, p. 41.
} 
deterioração da beleza sem gozar de tal constatação. Colocar no mesmo verso a palavra "mocidade" e "moda" mostram o caráter passageiro de ambas. Ainda percebemos nesse verso “Eu que amo a mocidade e as modas fúteis, vãs," , aquilo que Helder Macedo chamou de "coordenadas ideológicas"160 na obra de Cesário. O termo "vãs" pode fazer tanto relação com “modas", como com "mocidade", pois não é dito “...amo a mocidade as modas fúteis e vãs". Logo a mocidade é, tanto quanto a moda, inútil pois há de se dissipar. Por que, então, o poeta prefere o "cabelo escuro às veneráveis cãs", se a própria "mocidade" resulta inútil? Embora inútil, a mocidade supostamente mantém uma distância da morte. É a distância, na verdade, que o eu-lírico prefere.

Na perspectiva da escrita intimista, notamos com a leitura do poema, que não se trata, necessariamente, da escrita de um sujeito isolado do mundo. Que a solidão é um pressuposto para uma tentativa de compreensão de si e, por conseguinte, uma exigência dessa escrita intimista, não há dúvida. Mas não podemos pensar solidão somente como estar isolado da companhia do outro, há também uma solidão ontológica, aquela que o sujeito se sente só mesmo na companhia do outro. Essa solidão não nasce da distância que há entre sujeito e objeto, eu e outro. Essa solidão nasce da incompatibilidade entre as partes.

Desastre, o último poema deste período, trata de um acidente acontecido no ambiente citadino, onde este Eu toma 'corpo': "Este poema é a narrativa de uma ocorrência exemplar um acidente ou 'efeito casual' - usada como um facto significativo para caracterizar a situação miserável de um salariado, vitima típica de uma sociedade que ao mesmo tempo o explora e o despreza." ${ }^{161}$ Este salariado ou o acontecimento que este Outro se envolve, chama a atenção deste Eu, como que tirando-o do seu estado até então verificável, o amor-de-si do subtítulo deste capítulo e situando-o finalmente além das fronteiras do psicológico. Além disso, neste poema a cidade, assim como este Eu, toma 'corpo', não mais é implícita, mas ao contrário, descrita e habitada. Se causa estranheza esta última palavra acerca da cidade, devese lembrar que, a cidade, enquanto palco de ação, comportava somente um Eu e um Outro, e mesmo a situação do poema Ele, envolve um palácio real e a realeza, num plano satírico.

\footnotetext{
${ }^{160}$ MACEDO, Helder. Nós.

${ }^{161}$ Ibidem, pp. 88.
} 
Não há como negar a forte crítica social que este Eu faz aos seus pares. O morto passa, como um desfile fúnebre, pelas ruas, e este Eu, onisciente, vai mostrando as reações. Temos dois pólos, neste caso: daqueles que se 'emocionam', como "Um preto, que sustinha o peso dum varal,/Chorava ao murmurar-lhe: 'Homem não desfaleça!'”162 e seus companheiros de trabalho, impedidos de dar o adeus pelo patrão:

E o desgraçado? Ah! Foi para a vala imensa,

Na tumba, e sem o adeus dos rudes camaradas:

Isto porque o patrão negou-lhes a licença,

O inverno estava à porta e as obras atrasadas. ${ }^{163}$

No outro pólo temos porém, os habitantes desta cidade indiferentes aos fatos, como se tal acidente fosse tão corriqueiro quanto o passar das charretes:

Flanavam pelo Aterro os dândis e as cocottes,

Corriam char-à-bancs cheios de passageiros

E ouviam-se canções e estalos de chicotes,

Junto à maré, no Tejo, e as pragas dos cocheiros.

Viam-se os quarteirões da baixa: um bom poeta,

A rir e a conversar numa cervejaria,

Gritava para alguns: 'Que cena tão faceta!

Reparem! Que episódio!' Ele já não gemia. ${ }^{164}$

Um fidalgote brada a duas prostitutas:

"Que espantos! Um rapaz servente de pedreiro!"165

Neste poema, o Eu mostra-se literalmente muito pouco: na segunda quadra, quando diz: "E dentro eu divisei o ungido das desgraças,/Trazendo em sangue negro os membros

\footnotetext{
162 VERDE, Cesário,op.cit, p.100.

163 Ibidem, p.102.

${ }^{164}$ Ibidem, p. 100.

${ }^{165}$ Ibidem, p. 101.
} 
ensopados." ${ }^{166}$ e na décima-terceira quadra: "E eu tive uma suspeita.Aquele cavalheiro,/ Conservador, que esmaga o povo com impostos -, / Mandava arremessar - que gozo! estar solteiro! - Os filhos naturais à roda dos expostos..."167. O uso porém desta "narrativa em terceira pessoa'não atenua seu olhar indignado e sua posição política e social neste evento. Pela sua visão constrói este Outro antes de sua morte e sabemos, por exemplo, que "O mísero a doença, as privações cruéis/ Soubera repelir - ataques desumanos! / Chamavam-lhe garoto! E apenas com seis anos/ Andara a apregoar diários de dez-réis." ${ }^{168}$ Porém, a própria questão da construção desta 'narrativa' deva ser levada em conta e não parece ser de todo imprudente se questionar o quanto este Eu não é uma máscara e um reflexo deste meio. Ao delimitar dois pólos distintos de reações - aqueles que se comprazem e aqueles que não se importam - este Eu comparta-se muito mais como uma voz dos fracos do que um analista isento destes mesmos fatos. Daí a máscara política que se mune para falar deste acontecimento.Ao comentar sobre a persona, Jung nota: "A persona é um complicado sistema de relação entre a consciência individual e a sociedade; é uma espécie de máscara destinada, por um lado, a produzir um determinado efeito sobre os outros e por outro lado a ocultar a verdadeira natureza do individuo." ${ }^{\prime 69} \mathrm{O}$ efeito que causa o Outro neste $\mathrm{Eu}$, como já dito, desperta-o para as sensações fora de si e para um Outro que não somente será usado como contraposição na construção deste Eu, mas também será olhado além. O Outro não mais é um tipo ou uma memória: ele invadirá o universo deste $\mathrm{Eu}$, e passará a ser foco de sua atenção e sua solidariedade.

\footnotetext{
${ }^{166}$ Ibidem, p. 100.

${ }^{167}$ Ibidem, p. 102.

${ }^{168}$ Ibidem, p. 101.

${ }^{169}$ C.G. Jung. O Eu e o Inconsciente, $18^{\circ}$ Edição. Trad. Dora Ferreira da Silva. Petrópolis: Editora Vozes, 2004. Título do Original Alemão: Zwei Schriften Über Analytische Psychologie. Die Beziehungen zwischen den Ich und dem unbewussten. p. 68.
} 


\title{
Do amor ao outro ao desastre de si
}

\author{
"Eu não sou eu nem sou o outro, \\ Sou qualquer coisa de intermédio: \\ Pilar da ponte de tédio \\ Que vai de mim para o Outro." \\ (Mário de Sá-Carneiro)
}

Ao comentar o sentido da morte na poesia de Cesário Verde, Joel Serrão escreve:

"Vida e Morte: dados de um problema que os nossos antepassados próximos e longínquos não puderam encarar senão no seu conjunto; que também nós não podemos cindir mesmo que, por vezes, não tenhamos a consciência clara da indissolúvel relação. As soluções buscadas têm variado o e variam; no entanto, tornase evidente o predomínio de uma ou outra face da mesma realidade sob a forma de apologias da vida ou da morte. Não obstante, qual o valor de uma apologia da vida a não ser em função de uma dada visão da morte? ; como é que uma apologia explícita ou velada da morte não determina e não informa determinada forma de viver? Os homens vivem consoante a sua concepção da morte e morrem - ou procuram morrer de acordo com o significado e valor que atribuem à experiência vital. Quer aceite soluções religiosas quer as rejeite; quer viva em angústias incontidas quer em paz voluntária, feita de domínio e de recalcamentos - todo o ser bem consciente sabe que a morte é que acaba, afinal, por dar sentido à vida. Há no entanto, quem procure furtarse ao problema, ou mediante o exclusivismo da acção, ou até, na ideologia corrente de uma determinada época. Os homens morrem. Mas perante a verificação, em si trivial, uns procuram devassar o mistério que lhes depara, em busca de saciamento daquilo que Unamuno chamou 'el hambre de inmortalidad' ; outros recalcam angústias latentes, dominam-nas, e só em momentos de crise ou de evasão, a problemática recalcada e adiada se instala à plena luz da consciência..."170

A constatação da finitude do Outro, e consequentemente de usa própria finitude, faz o Eu colocar em questão não somente a si: o mundo, enquanto palco de seu drama particular, adquire significados mais reais e complexos. A realidade visível e tangível se torna objeto ela mesma de uma análise e torna-se também um interlocutor neste diálogo em que intenta a

\footnotetext{
${ }^{170}$ SERRÃO, Joel. Sobre o sentido da morte na poesia de Cesário Verde. In: Estrada Larga, p. 403.
} 
impossível restauração de si mesmo. Se o desconcerto inicial é pessoal, ontológico, agora se torna coletivo, social. Sua restauração fundamenta-se na idéia da poetização: poetizar o cotidiano é, ao mesmo tempo, encontrar para si uma posição e uma função dentro de um mundo que funciona sob mecanismos hierarquizantes e também transcender o contato com este cotidiano e consigo mesmo.

Nevroses ${ }^{171}$ introduz o Eu que encontra uma função $^{172}$. Neste poema, percebemos um Eu exasperado por seus problemas com seus versos não publicados. Dói-lhe a cabeça e sentese cruel:

Eu hoje estou cruel, frenético, exigente;

Nem posso tolerar os livros mais bizarros.

Incrível! Já fumei três maços de cigarros

E agrado a pouca gente.

Dói-me a cabeça. Abafo uns desesperos mudos:

Tanta depravação nos usos, nos costumes!

Amo, insensatamente, os ácidos, os gumes

E os ângulos agudos. ${ }^{173}$

O primeiro verso mostra duas importantes características na constituição deste Eu: a primeira, a questão da temporalidade. O "hoje" traz a leitura para um plano mais 'real' e próximo. E o uso dos assindéticos, tal qual na primeira frase, possibilita a construção do sentido não somente um a um, mas também pela soma dos significantes. Pensando na questão de como a temporalidade é uma forma de 'estar ali', ou seja, o Eu definir tempo e espaço como condições inerentes a si mesmo, pode-se pensar que os adjetivos "cruel, frenético, exigente" digam não apenas sobre o estado espiritual ou emocional deste $\mathrm{Eu}$, mas também sobre a própria condição do lócus onde se constitui. Este Eu assume, de fato, tais características, mas muito mais enquanto reflexo do que enquanto condição própria. Daí a contradição, ou a declaração de que "amo, insensatamente, os ácidos, os gumes/ E os ângulos

\footnotetext{
${ }^{171}$ Em O Livro de Cesário Verde: Contrariedades.

${ }^{172} \mathrm{O}$ sentido que damos de função ao falar da poesia de Cesário pode ser definido como o Eu que nomeia-se através de uma profissão ou atividade.

${ }^{173}$ VERDE, Cesário, op.cit, p. 105.
} 
agudos". É insensato este amor, expressamente se declara a insensatez, e, tais elementos são externos como a cidade e a constituição social, e consequentemente análogos à "depravação nos usos, nos costumes". Seu desespero estaria, então, na impossibilidade ou na dificuldade de ser ele mesmo e constituir-se ali, naquele espaço e tempo. Neste espaço ele se depara com um novo tipo de Outro; para a idéia de sociedade e hierarquia ser crível, este Outro também adquire uma função. Neste caso, a mulher é uma engomadeira, e como ele, sofre também as influências do meio:

Sentei-me à secretária. Ali defronte mora

Uma infeliz, sem peito, os dois pulmões doentes;

Sofre de faltas de ar, morreram-lhe os parentes

E engoma para fora.

Pobre esqueleto branco entre as nevadas roupas!

Tão lívida! O doutor deixou-a. Mortifica.

Lidando sempre! E deve conta à botica!

Mal ganha para as sopas... ${ }^{174}$

A 'infeliz' é destituída, pela visão deste Eu, inclusive de seu peito. Tal peito também pode ser visto como indicativo da própria feminilidade da mulher, esteticamente dizendo, e da própria 'função', biologicamente pensando, pois sem peito, sequer poderia amamentar e cumprir seu papel de mãe. Por isso, é apenas um 'esqueleto branco', sem voz que este Eu intenta dar, ao mudar o 'foco narrativo', passando da primeira pessoa para a terceira em seis das dezessete quadras que compõem o poema. Numa delas ele fala do 'populacho':

Com raras excepções, merece-me o epigrama.

Deu meia-noite, e em paz pela calçada abaixo

Soluça um sol-e-dó. Chuvisca.O populacho

Diverte-se na lama. $^{175}$

\footnotetext{
${ }^{174}$ Ibidem, p. 105.

${ }^{175}$ Ibidem, p. 106.
} 
Este divertir-se na lama, ressalta ainda mais a idéia de uma urbs decaída, concordando com o fato de tal decadência somente causar doenças(como a falta de ar da tísica e as dores de cabeça do $\mathrm{Eu})$ e que tal meio não poderia apreciar algo que este Eu considera acima desta lama, ou mesmice. Produto deste meio, o estudo ou a perpetuação da ordem estabelecida também é criticado, assim como a tradição artística :

Que mau humor! Rasguei uma epopéia morta

No fundo da gaveta. O que produz o estudo?

Mais duma redacção, das que elogiam tudo,

Me tem fechado a porta.

A crítica segundo o método de Taine

Ignoram-na. Juntei numa fogueira imensa

Muitíssimos papéis inéditos. A imprensa

Vale um desdém solene. ${ }^{176}$

Pensando-se como o Eu se constituí aqui, podemos notar ser ele um escritor, rejeitado pelos jornais e ignorado pela crítica. Esta condição deixa-o colérico, e sente-se assim muito próximo da tísica fechada em seu quarto, abandonada:

O obstáculo ou depura ou torna-nos perversos;

Agora sinto-me eu cheio de raivas frias,

Por causa dum jornal me rejeitar, há dias,

Um folhetim de versos. ${ }^{177}$

Este confessar sua perversão é o cerne do poema. Defronte à si e em sua volta, o mundo 'desaba' ou morre, mas sua preocupação está centrada em si mesmo. Em doze quadras fala ou pensa sobre si, em contraponto as cinco em que vê a tísica e uma que, inicia falando de si e termina olhando um pouco além, o já citado populacho. Pensando em si, vai se definindo ou definindo o seu fazer artístico em relação ao ‘senso comum’ da crítica:

\footnotetext{
${ }^{176}$ Ibidem, p. 106.

${ }^{177}$ Ibidem, p. 105.
} 
Eu nunca dediquei composições nenhumas,

Senão, por deferência, a amigos ou artistas.

Independente! Só por isso os jornalistas

Me negam as colunas.

Receiam que o assinante ingênuo os abandone,

Se forem publicar tais coisas, tais autores.

Arte? Não lhes convém, visto que seus leitores

Deliram por Zaccone.

Um prosador, aqui, desfruta fama honrosa,

Obtém dinheiro, arranja a sua coterie;

E a mim, não há questão que mais me contrarie

Do que escrever em prosa.

A adulação repugna aos sentimentos finos;

Eu raramente falo aos nossos literatos,

E apuro-me em lançar originais e exactos,

Os meus alexandrinos... ${ }^{178}$

Estas quadras ganham grande importância para se constituir este Eu que se constitui enquanto poeta. Ao dizer-se contrariado com a prosa ele, inserido no seu tempo, critica a prosa que somente adula e mantém o leitor ingênuo, e critica o fato da poesia não ter tanta importância, por isso seus versos não falarem com os literatos, numa clara idéia de que aquela forma estar mais em voga do que esta que tanto se esmera em fazer. Este mesmo esmero levanta uma contradição: por seus versos serem 'exatos e alexandrinos' significaria que este Eu obteve tal técnica pelo estudo, colocado em questão na sexta quadra, o que faria com que, em detrimento da forma, a 'originalidade' do tema ou do conteúdo fossem mais destacados. O valor deste conteúdo pode ser visto também quando diz que os editores poderiam contrariar o leitor ingênuo ao publicá-lo. Tal originalidade ganha ainda mais corpo ao lembrar-se de que este Eu rasga uma epopéia morta, num ato que significaria tanto a crítica à tradição quanto ressaltaria ainda mais o caráter original do que escreve.

${ }^{178}$ Ibidem, p. 106-107 
Aquele mesmo meio que o incomoda, e que ama insensatamente, o seduz de tal forma que na última quadra, ao declarar saber como lidar com este meio, declara estar melhor. Mas nesta mesma quadra, ao demonstrar sua preocupação pela vizinha, chama sua atenção o fato de trabalhar e ser feia:

E estou melhor; passou-me a cólera.E a vizinha?

A pobre engomadeira ir-se-á deitar sem ceia?

Vejo-lhe luz no quarto. Inda trabalha.É feia...

Que vida! Coitadinha! ${ }^{179}$

Antes de qualquer conclusão e para se ressaltar o que foi dito anteriormente na questão de que este Eu e este Outro se unem pela solidariedade de sofrerem por causa do meio, vale lembrar esta quadra:

Nem pão no armário, ó Deus! Chama por ela a cova.

Esvai-se; e todavia, à tarde, fracamente,

Ouço-a cantarolar uma canção plangente

Duma opereta nova! $!^{180}$

Como já dito, esse mesmo meio que causa o sofrimento também os seduz, quer seja o Eu pela idéia de publicar seus versos para leitores que vivem nesta cidade, quer seja o Outro cantarolando músicas que estão 'na moda'. Tal solidariedade parece ficar restrita porém nos versos, e em menos versos do que aqueles em que pensa em si. Ao falar da tísica, o uso da pontuação - em especial o ponto de exclamação - demonstra a entonação que sobe à níveis dramáticos, como a demonstrar um caráter emotivo, porém a construção das descrições desta mulher em contradição a linguagem quase coloquial e prosaica que usa para falar de si, cria uma áurea de falseamento artístico. Como exemplo mais claro os versos: "Pobre esqueleto branco entre as nevadas roupas!/ Tão lívida!”, “Lidando sempre!”, “Nem pão no armário, Oh Deus! Chama por ela a cova."ou a quadra:

\footnotetext{
${ }^{179}$ Ibidem, p. 107.

${ }^{180}$ Ibidem, p. 107.
} 
E a tísica? Fechada, e com o fero aceso!

Ignora que a asfixia a combustão das brasas,

Não foge do estendal que lhe humedece as casas,

E fina-se ao desprezo!

Notes-se a diferença quando pensa em si, na quadra:

Perfeitamente. Vou findar sem azedume.

Quem sabe depois, eu rico e noutros climas,

Conseguirei reler estas antigas rimas,

Impressas em volume?

Questionar a intencionalidade deste $\mathrm{Eu}$, ou se realmente se compraz deste Outro não parece ser um exercício claro ou que esclareça esta leitura. Que há o olhar deste Eu para fora de si, e tal atitude já é por si só solidária, não há dúvidas. A questão levantada, da perversão, que surge de um obstáculo externo, como declara, justificaria a atitude egoísta deste Eu, e, tal qual um produto do meio, insensibilizado pela Babel, e já transformado ele também em mecanismo, impossibilitaria este Eu de genuinamente compartilhar os problemas deste Outro. Umberto Eco tece o seguinte comentário:

"Diante da opressividade do mundo industrial, das metrópoles percorridas por multidões imensas e anônimas, da insurgência de um movimento operário organizado e do florescimento de uma forma de jornalismo que, publicando novelas populares em capítulos, dá inicio àquilo que hoje chamamos de cultura de massa, o artista vê ameaçado os seus ideais, percebe as idéias democráticas como inimigas, resolve ser 'diferente', marginalizado, aristocrático ou 'maldito' e retira-se para a torre de marfim da Arte pela Arte. Como dirá Villiers de I'arlisle-Adam: 'Viver? Os criados pensarão nisso por nós'. Assim, a época do triunfo da máquina e do culto positivista da ciência é também do Decadentismo. Ganha forma uma religião estética segundo a qual a Beleza é o único valor que deve ser realizado, e para um dandy a própria vida deve ser vivida como obra de arte. Em sua poesia Langor(1883), Paul Valerie compara sua época ao mundo da decadência romana ou bizantina; tudo já foi dito, os prazeres experimentados e sorvidos, perfilam-se no horizonte as ordens de bárbaros que a civilização doente não saberá deter. Nada resta, dirá Huysmans, senão mergulhar nas alegrias dos sentidos de uma imaginação superexcitada, listar os tesouros da arte, 
deslizar as mãos por jóias acumuladas por gerações passadas. Para Baudelaire (As correspondências, 1857), 'a natureza é um templo vivo em que os pilares deixam filtrar não raro insólitos enredos', e que só pode ser vista como inexaurível reserva de símbolos. Mas se tudo permite uma revelação simbólica, deve-se procurar por ela também nos abismos do mal." 181

Tais abismos, como este Eu percebe, só podem ser verdadeiramente compreendidos se sentidos, quer seja uma sensação externa que inunda-o ou uma sensação interna que irrompe e transfigura o que vê. Em Num Bairro Moderno o externo ao Eu não somente o caracteriza mas a própria existência deste Eu e suas sensações são imanentes deste meio. De fato, temos diversos focos que se cruzam, e este Eu torna-se apenas um catalisador ou o testemunho deste processo. "Dez horas da manhã," é a frase inicial do poema e evoca um dado empírico, assim como o espaço, a data, o clima também o são, concordando com a idéia da definição do "ser en el mundo" de Heidegger:

'Ser en el mundo' quiere decir, según la exégis hecha hasta aqui: el absorberse, no temáticamente, sino 'viendo en torno', en las 'referencias' constitutivas del 'ser a la mano' del todo de útiles. El 'curarse de' es en cada cada caso ya como es, sobre la base de una familiaridad con el mundo. En esta familiaridad puede el 'ser ahí' perderse en lo que hace dentro del mundo y ser captado por ello. ${ }^{182}$

A idéia da 'familiaridade' que libertaria o Eu e permitiria que o mundo o capturasse parece um pequeno resumo do poema. No primeiro momento, o foco centra-se no geral: temos a noção de tempo, de espaço, detalhes de onde o Eu se encontra são dados, personagens são inseridos na trama. :

Dez horas da manhã; os transparentes

Matizam uma casa apalaçada;

Pelos jardins estancam-se as nascentes,

E fere a vista, com brancuras quentes,

A larga rua macadamizada.

\footnotetext{
${ }^{181}$ Umberto Eco. História da Feiúra. Trad. Eliana Aguiar. Rio de Janeiro: Editora Record, 2007. Título original: Storia della bruttezza. p. 350.

${ }^{182}$ Martin Heidegger, El Ser y el tiempo, $4^{\circ}$ Edição. Trad. José Gaos. México: Editora Fondo de Cultura Económica,1971. Título original: Sein und Zeit. p. 90.
} 
Réz-de-chaussée repousam sossegados,

Abriram-se, nalguns, as persianas,

E dum ou doutro, em quartos estucados,

Ou entre a rama dos papéis pintados,

Reluzem, num almoço, as porcelanas.

Como é saudável ter o seu conchego,

E a sua vida fácil! Eu descia,

Sem muita pressa, para o meu emprego,

Aonde agora quase sempre chego

Com as tonturas duma apoplexia. ${ }^{183}$

O foco que se inicia geral vai se aproximando dos objetos. Depois, se afasta. Depois se aproxima novamente e continua nesse processo de longe-perto, dentro-fora, por todo o poema. Quando se diz 'dentro-fora', deve se entender como pessoal-impessoal, como quando o Eu comenta: "Como é saudável ter o seu conchego,/E a sua vida fácil”, pois em determinado momento, tomado pelas sensações do meio, este Eu é absorvido de tal forma que as sensações em si definem-no, e não mais ele enquanto ser. As sinestesias transformam-no em um catalisador, um imã e também um observador de si.

No primeiro momento, no entanto, as marcas de sua consciência ainda são evidentes, como quando nota uma rapariga e a examina. Neste caso, o comentário social prevalece sobre o mero observar. Ele não é imparcial e parece claro que a cena que se segue causa uma ruptura profunda tanto no poema em si quanto na constituição deste Eu: ele transforma-se num artista, e epifanicamente, a harmonia entre os 'personagens do poema' até então ausente, instaura-se :

E rota, pequenina, azafamada,

Notei de costas uma rapariga,

Que no xadrez marmóreo duma escada,

Como um retalho de horta aglomerada,

${ }^{183}$ VERDE, Cesário, op.cit, p. 116. 
Pousara, ajoelhado, a sua giga.

E eu, apesar do sol, examinei-a:

Pôs-se de pé, ressoaram-lhe os tamancos;

E abre-se-lhe o algodão azul da meia,

Se lhe curva, esgadelhada, feia,

E pendurando os seus bracinhos brancos.

Do patamar responde-lhe um criado:

'Se te convém, despacha; não converses.

Eu não dou mais.' E muito descansado,

Atira um cobre ignóbil, oxidado,

Que vem bater nas faces duns alperces.

Subitamente, - que visão de artista! -

Se eu transformasse os simples vegetais.

À luz do sol, o intenso colorista,

Num ser humano que se mova e exista

Cheio de belas proporções carnais?! ${ }^{184}$

A visão de artista, auto-proclamada, abre todos os seus sentidos, e capta, neste ambiente citadino, os sons, os cheiros e as cores. E, tal como um demiurgo, a partir de um cesto de vegetais, decide criar um ser humano cheio de 'belas proporções carnais':

Bóiam aromas, fumos de cozinha;

Com o cabaz às costas, e vergando,

Sobem padeiros, claros de farinha;

E às portas, uma ou outra campainha

Toca, frenética, de vez em quando.

E eu recompunha, por anatomia,

Um novo corpo orgânico, aos bocados.

${ }^{184}$ Ibidem, p. 116-117. 


\section{Achava os tons e as formas. Descobria \\ Uma cabeça numa melancia, \\ E nuns repolhos seios injetados. ${ }^{185}$}

Observando o cesto, este Eu encontra semelhanças entre os vegetais e um ser humano. Não é um ser humano desprovido de gênero porém e sim uma mulher com "seios injectados" e "um ventre": "O ser humano vegetal que emerge da cornucópia trazida para a cidade pela frágil mensageira do campo é uma mulher gigantesca com grandes seios maternais('seios injetados') e opulentas 'carnes tentadoras'; uma Deusa-Mãe arquetipal, uma personificação da Natureza." " Este ser criado por sua vez, possibilita que enxergue ali também um feto:

E como um feto, enfim, que se dilate,

Vi nos legumes carnes tentadoras,

Sangue na ginja vívida, escarlate,

Bons corações pulsando no tomate

E dedos hirtos, rubros, nas cenouras. ${ }^{187}$

Ao comentar a sobrevalorização do útil de uma sociedade de consumo, em contraste com a 'ociosidade' do fazer poético, Álvaro Cardoso Gomes escreve:

“ A sobrevalorização do útil, da mercadoria, do valor de troca tem outro agravante: o de desprezar e condenar o ócio, que o poeta assume, às vezes, com sentimento de culpa. Afinal, ele é um privilegiado que sem muita pressa desce para seu trabalho. No poema 'Num Bairro Moderno', de um lado, o ócio torna-se positivo, pois permite ao poeta observar o mundo e encharcar-se do real visível, mas, de outro, torna-se negativo, quando ele se defronta com a vendedora de hortaliças. Sua má consciência só se aplaca no instante em que procura ajudá-la a erguer a cesta de legumes e hortaliças(...). Ao ajudá-la, o poeta atravessa a fronteira das classes: o 'eu' transmuda-se em 'nós', e o esforço conjugado de ambos vence a força da gravidade que atraía o gigo para o chão de pedra. Ao mesmo tempo, o sujeito faz referência ao 'enorme esforço muscular', de todo ausente em seu deambular vagabundo ou em sua

\footnotetext{
${ }^{185}$ VERDE, Cesário, op,cit, p. 117.

${ }^{186}$ MACEDO, Helder, op. cit, p. 115.

${ }^{187}$ VERDE, Cesário, op.cit. p. 118.
} 
atividade solitária de poeta. Desse modo, se verifica que Cesário vive sob o signo da consciência cindida(...)."

A percepção de que, enquanto artista, e consequentemente 'culpado', poderia ser a explicação de imaginar no cesto da verdureira a gênesis de uma vida criada a partir da Natureza, uma segunda chance ao homem: "Uma vez que o poeta recompõe, isto é compõe de novo um 'novo corpo orgânico' com os frutos e legumes vistos em termos metafóricos ${ }^{189}$ ('descobria / uma cabeça numa melancia...'), a sua actividade implica a existência anterior de um modelo ou arquétipo, de uma 'idéia' no sentido platônico, que houvesse sido decomposto em frutos e legumes. Esse modelo é portanto, a própria Natureza. Mas como o corpo que é recomposto é um corpo 'novo', fica também implícito que a Natureza, no processo da sua decomposição, tinha perdido a sua forma ou totalidade original. A 'visão de artista' ganha, assim uma dimensão mais ampla e mais profunda: é um projecto 'visionário' de reconquista de um paraíso perdido.",190

Paraíso este, que o Eu, pela visão de artista tenta reconstruir dentro do esquema do poema, poetizando e 'pintando' uma cena aparentemente trivial, apoética:

"O jóquei da tartaruga(...)deixa-se levar pelo ritmo do seu corcel, que se desloca lentamente ou imprevistamente pára ante um acontecimento. Mas a corrida não tem um fim: a finalidade da caminhada está na própria caminhada.O jóquei não vai a lugar algum,e, mesmo quando se dirige a um local específico, quer antes gozar do espetáculo variado que a cidade lhe oferece.(...) Assim, o jóquei da tartaruga, em seu andar moroso, realiza duplo papel poético: de um lado, mostra absoluta eficiência em captar os múltiplos aspectos que a cidade lhe oferece, transformando-se num repórter de seu tempo, de outro lado, mostra sua competência em desalienar o homem,

${ }^{188}$ GOMES, Álvaro Cardoso. O Jóquei da Tartaruga. In O Poético: Magia e iluminação. São Paulo: Editora Perspectiva, 1998. p. 150.

189 Helder Macedo nota que Óscar Lopes, ao chamar a atenção para o que designa como 'metáforas substantivas' na obra de Cesário, perceptivamente caracteriza esse processo de transformação de símile em metáfora, ou de designação em conotação: “Mas atentemos nas imagens e metáforas 'substantivas'. O propósito dominante não é o de transcender a realidade positiva da percepção comum, mas o de surpreende-la em imagens típicas; e disso resulta que muitas das suas metáforas (ou translação de significado) se mascaram sob a forma de simples comparações: há, por exemplo, uns ceguinhos que 'rolam os olhos como dois escarros', comparação de tal modo forte e arrepiante, que equivale a uma transfiguração metafórica. No entanto, verificaremos que, em grande parte sem dar por isso, a observação seletiva, à força de querer-se exacta, se excede e transforma em metáfora." Oscar Lopes, Cesário Verde, ou do Romantismo ao Modernismo, em História da Literatura Portuguesa, II, pp. 626.

${ }^{190}$ MACEDO, Helder, op.cit, p. 117. 
liberando-o da opressiva indiferenciação imposta pela massa. Isto se dá pelo efeito mágico da poesia que recusa o útil, o progresso, mas se dá também no instante em que ela faz que cada coisa, cada ser recupere sua aura. ${ }^{191}$

Cristalizações, em certa medida, repete a 'fórmula' de Num Bairro Moderno: temos um Eu que também torna-se um artista, o espaço físico se torna de extrema importância para a compreensão do que este mesmo Eu chama de peça:

Faz frio. Mas, depois duns dias de aguaceiros,

Vibra uma imensa claridade crua.

De cócoras, em linha, os claceteiros,

Com lentidão, terrosos e grosseiros,

Calçam de lado a lado a longa rua.

Como as elevações secaram do relento,

E o descoberto sol abafa e cria!

A frialdade exige o movimento;

E as poças de água, como um chão vidrento,

Refletem a molhada casaria.

Em pé e perna, dando aos rins que a marcha agita,

Disseminadas, gritam as peixeiras;

Luzem, aquecem na manhã bonita,

Uns barracões de gente pobrezita,

E uns quintalórios velhos, com parreiras. ${ }^{192}$

Neste poema, o traço da solidariedade também está em encontrar no fugaz, no trivial e naquilo que emana desses trabalhadores, objetos artísticos. Mas, diferentemente do poema anteriormente discutido, a solidariedade deste Eu com os trabalhadores mantêm-se enquanto estes são objetos de observação. Mesmo quando comenta a situação a exaspera-se com ela, o faz com olhos de artista, e tais olhos se distraem ao visualizar uma atriz conhecida. A dita

${ }^{191}$ GOMES, Álvaro Cardoso, op cit, p.140 e 150.

${ }^{192}$ VERDE, Cesário, op.cit., p. 122. 
estilização dos trabalhadores, e conseqüentemente a solidariedade termina quando esta mulher surge.

E engelhem muito embora, os fracos, os tolhidos,

Eu tudo encontro alegremente exacto.

Lavo, refresco, limpo os meus sentidos,

E tangem-me, excitados, sacudidos,

O tacto, a vista, o ouvido, o gosto, o olfacto! ${ }^{193}$

Homens de carga! Assim as bestas vão curvadas!

Que vida tão custosa! Que diabo!

E os cavadores descansam as enxadas,

E cospem nas calosas mãos gretadas,

Para que não lhes escorregue o cabo.

Povo! No pano cru rasgado das camisas

Uma bandeira penso que transluz!

Com elas sofres, bebes, agonizas:

Listrões de vinho lançam-lhe divisas, E os suspensórios traçam-lhe uma cruz! $!^{194}$

Feito tais comentários, causa estranheza a mudança de foco para a atriz, e para novamente seus desejos e para si. Mas, observando-se seus traços e principalmente sua função social, o trabalho de atriz, o contraste que faz com os trabalhadores demonstra a admiração que neles deposita. Este Eu, como em Num Bairro Moderno, parece ter encontrado por trás da máscara do artista, a solução para sua própria constituição: seu novo credo torna-se o meio, o ambiente externo e neste encontra a possibilidade de constituir-se. Porém, não é somente enquanto um comentarista social, mas um artista que absorve e transforma este meio, e justifica, como uma desculpa, sua constituição.

${ }^{193}$ Ibidem, p. 124
${ }^{194}$ Ibidem, p. 124. 
Há de se pensar também se esse achar-se no mundo enquanto artista não é o curar-se. Se, num primeiro momento o olhar para si, para as relações com um Outro revelam sua inaptidão para conciliar-se com o Outro e consigo, e após a constatação da finitude não somente do Outro mas também de si tal relação ganha um caráter mais solidário, é quando se constitui como um artista do real que de fato se 'encontra'. Neste momento, sua visão se abre e, ao transformar em arte o cotidiano, e principalmente 'pintar' os quadros sociais de forma poética, o Eu constitui-se de forma plena, madura e segura. Dilui-se então no próprio texto, e de certa maneira invulnerável ao próprio meio, escreve de si descrevendo o meio. A técnica de mudar o foco então torna-se ela mesma uma forma de se confundir com o que observa. Com isso, a independência que ganha se si mesmo mascara de certa forma seus sentimentos e são, antagonicamente, as sensações 'puras' causadas por esse observar . O esteta se descobre um Eu, e o Eu repousa nessa confiança artística.

Tal conciliação porém não durará muito. O mesmo meio que oferece a musa, também oferece a dor. Noitada ${ }^{195}$ é um representante desta idéia. Vemos o Eu caminhando com uma mulher, num passeio onde há no início harmonias aparentemente dicotômicas: entre os elementos naturais e os artificiais do meio, e entre este Eu e Outro:

Lembra-te tu do sábado passado,

Do passeio que demos, devagar,

Entre um saudoso gás amarelado

E as carícias leitosas do luar?

Eu lembro bem as altas ruazinhas, Que ambos nós percorremos, de mãos dadas;

As janelas palravam as vizinhas;

Tinham lívidas luzes as fachadas. ${ }^{196}$

As imagens tornam-se pesadas e escuras, bem ao contrário de Num Bairro Moderno em que o sol está presente de forma incisiva: quer literalmente, em quatro ocasiões citado nominalmente, quer metaforicamente( 'os transparentes / matizam uma casa apalaçada'). A

\footnotetext{
195 Título em O Livro de Cesário Verde: Noite Fechada.

${ }^{196}$ VERDE, Cesário, p. 125
} 
luz aqui se dá pelo luar, e pelo gás amarelado das lâmpadas artificiais. A cidade apresentada lembra em tudo um grande cemitério e uma grande prisão. "Em 'Noite Fechada'197, a cidade é explorada de dentro e o campo é o refúgio procurado pelo narrador para nele ir meditar sobre o malogro de uma relação amorosa citadina definida nos termos da noite constritora que é a 'noite fechada' do título do poema. Noite e cidade são, portanto, equivalente simbólicos. A impossibilidade do amor na cidade é uma conclusão implícita.(...)"198

Diria-se que o amor torna-se impossível na cidade também por tal amor do Eu estar voltado para uma mulher insensível as mazelas e incongruências citadinas, e, tal qual um animal, ser simplesmente produto deste meio. A idéia da seres produtos do meio também está em Cristalizações. A zoomorfização dos trabalhadores "como animais comuns", "bovinos" e da mulher com "pezinhos rápidos, de cabra" diz mais sobre o Eu do que sobre estes Outros. É sua visão que os transforma e sua crença na "fina arte", transforma o Outro em elemento integrante este meio e isola-se através de 'sua visão de artista' deste meio empírico pela transfiguração dos objetos em linguagem artística. Mas sua crença na arte, como meio redentor de si e como uma ponte que uniria o Eu e Outro, começa a diminuir, pois essa arte não ergue em sua volta uma barreira que o torne invulnerável aos sentimentos alheios e aos seus próprios. E são estes que o Eu teme neste poema específico:

\section{E eu que busco a moderna e fina arte, \\ Sobre a umbrosa calçada sepulcral, \\ Tive a intenção de violentar-te \\ Imbecilmente como um animal! ${ }^{199}$}

Sua própria zoomorfização pode ser reflexo tanto desta cidade que tem aspectos de cemitério quanto pela mulher, desdenhosa e indiferente ao que o Eu observa. Se, de um lado, temos um Eu melancólico e por vezes revoltado, também temos, por outro lado, um Outro que demonstra óbvia 'alegria descompromissada'. A tristeza e a melancolia deste Eu são demonstradas através dos elementos externos e dos comentários deste em relação ao que vê. A cidade, adquire ares sepulcrais, decadentes e asfixiantes:

\footnotetext{
${ }^{197}$ Helder Macedo utiliza o título de O Livro de Cesário Verde.

${ }^{198}$ MACEDO, Helder, op.cit, p. 155.

${ }^{199}$ VERDE, Cesário, op.cit, p. 128
} 
Não me esqueço das cousas que disseste,

Ante um pesado templo com recortes;

E os cemitérios ricos, e o cipestre

Que vive de gorduras e de mortes! $!^{200}$

$$
\text { (...) }
$$

Não me esquece ainda meu o meu desgosto

Nem o sino rachado que deu horas. ${ }^{201}$

A lua dava trémulas brancuras.

Eu ia cada vez mais magoado;

Vi um jardim com árvores escuras,

Como uma jaula todo gradeado!

E para te seguir entrei contigo

Num pátio velho que era dum canteiro,

$E$, onde talvez, se faça inda o jazigo

Em que eu irei apodrecer primeiro! ${ }^{202}$

O "sino rachado que deu horas" é a figura perfeita para exemplificar o estado psicológico e emocional deste Eu. Se antes, se aventou a idéia dos marcos estruturais externos, como o tempo e o clima como condições constituintes deste $\mathrm{Eu}$, o estado do sino que dá horas demonstraria como se sente e se vê este Eu. O sino, objeto construído para regular a noção de tempo e também, entre outras funções, para homenagear os mortos (as badaladas durante a cerimônia de sepultamento são exemplo dessa idéia) ou celebrar núpcias, está rachado, cindido como este Eu. A sua melancolia e seu pesar estão no fato de, por um lado, amar esta mulher inconseqüente e por outro, saber da impossibilidade de tal relação se consumar. Ironicamente, o badalar deste sino serve para ambas as funções: decidindo por ficar com esta mulher, decretaria a morte de sua consciência social, porém decidindo pelo contrário, ao afastar-se, decretaria sua morte emocional. No primeiro caso, celebraria núpcias

\footnotetext{
${ }^{200}$ Ibidem, p. 126.

${ }^{201}$ Ibidem, p. 126

${ }^{202}$ Ibidem, p. 127.
} 
com este Outro. No segundo, com sua consciência. A presença do padre nesta mesma situação colabora para esta idéia de casamento e sepultamento.

A inconsequiência ou inconsciência desta mulher em contraste com o olhar deste Eu, que repara e analisa, são notórios nestes versos:

Tenho ainda gravado no sentido,

Porque tu caminhas com prazer,

Cara rapada, gordo e presumido,

O padre que parou para te ver.

Como uma mitra a cúpula da igreja

Cobria parte do ventoso largo;

E essa boca viçosa de cereja,

Torcia risos com sabor amargo. ${ }^{203}$

Sei que em tudo te atentavas, tudo vias!

Eu por mim tinha pena dos marçanos,

Como ratos, nas gordas mercearias,

Encafurnados por imensos anos!

Tu sorrias de tudo: os carvoeiros

Que aparecem ao fundo dessas ruínas,

E à crua luz os pálidos barbeiros

Com óleos e maneiras femininas! ${ }^{204}$

Inesperadamente porém, o Eu, até então solidário deste povo, revolta-se contra este mesmo povo, num aparente desatino. Helder Macedo assim pensa sobre tal situação:

“A percepção angustiada deste efeito pessoalmente opressivo da cidade resulta, no entanto, de uma intensa observação social que a torna exemplarmente

${ }^{203}$ Ibidem, p. 126.

${ }^{204}$ Ibidem, p. 127. 
extensiva à multidão de habitantes cujas vidas estão sujeitas ao mesmo mortal aprisionamento da cidade. Os marçanos encafurnados, os carvoeiros soterrados, os barbeiros sem sol - equivalentes humanos das metafóricas 'árvores escuras' enjauladas num jardim gradeado - são exemplos típicos da condição do trabalhador anônimo numa cidade que transforma os indivíduos em cifras na multidão. A condição alienada destes indivíduos anônimos é acentuada pela evocação da 'miséria em bando'do povo comum em busca dos prazeres narcóticos dos fins-de-semana:

Fins-de-semana! Que miséria em bando!

O povo folga, estúpido e grisalho!

E os artistas de ofício iam passando,

Com as férias, ralados do trabalho.

O contraste entre os graves 'artistas de ofício', significativamente caracterizados, em termos de classe, como salariados, e o bando inconsciente da multidão em triste folga, é desenvolvido, nos versos seguintes, através do exemplar 'quadro interior' do homem que, à luz da candeia, 'ensina a filha a ler', uma visão que, no contexto, funciona como um comentário revoltadamente compadecido pela inviabilidade implícita do seu esforço individual de superação da miséria inerente à sua classe social:

O quadro inferior, dum que à cadeia,

Ensina a filha a ler, meteu-me dó!

Gosto mais do plebeu que cambaleia,

Do bêbado feliz que fala só!

A explosão pessimista contra a 'estupidez grisalha' das massas anônimas durante as horas de lazer e o contrapontístico comentário de amarga compaixão sobre o indivíduo solitário que ensina a filha a ler convergem na brutal afirmação de preferência pelo entorpecido 'plebeu que cambaleia' e 'fala só' ao virtuoso plebeu que ensina a filha a ler.,205

Tirante a óbvia crítica social que este Eu formula pelo impacto deste contraste, pela perversão das inversões de valores, em que o individuo que se esforçaria teria tanto ou menos valor que aquele que apenas folgueia, pois a cidade enquanto metonímia desta sociedade industrial impediria qualquer ascensão social, também há a incredibilidade deste Eu em relação ao poder da escrita. Neste ponto, vemos já uma desesperança deste Eu na escrita e consequentemente em si mesmo. A arte, no final das contas, não o redime de si e do meio. $\mathrm{O}$

${ }^{205}$ MACEDO, Helder, op.cit. p. 158. 
credo que este eu depositava no fazer artístico como um remédio salutar para a dicotomia ser eu / ser outro, mostra-se inócuo.

\section{Mas ao rumor dos ramos e da aragem, \\ Como longíquos bosques muito ermos, \\ Tu querias no meio da folhagem \\ Um ninho enorme para nós vivermos. ${ }^{206}$}

Esta quadra é de suma importância para o entendimento daquilo que o próprio Eu chamará de 'desterro'. O poema nos mostra este Eu acompanhando uma mulher a quem a cidade já não mais comove nem incita; ela a tudo vê e não demonstra qualquer preocupação com a desordem estabelecida e com a condição desumana conseqüente. Em dado momento, no entanto, ela abre-se a perspectiva de uma vida amorosa longe deste meio, porém a reação deste Eu é sentir-se desterrado. Este ninho enorme, este paraíso que só existe dentro deste $\mathrm{Eu}$, subitamente, poderia ser maculado. É como se, tal qual um Adão, o Eu se visse as voltas com uma mulher que não fosse a Eva original. A imagem dela o relembraria sempre do paraíso, perdido pela consumação desta relação e consequentemente imaculado. Mas tal situação o põe pensativo e ele repara no rio a correr, como o tempo. O amor que ele deseja não deve ser dedicado à uma mulher que seja como ele, mas que também compreenda a importância do papel que este Eu assume para si: o de buscador da moderna e fina arte:

"A necessidade que ele sente de obliterar a sua consciência angustiada num acto de violência física é tanto uma fuga no irreal quanto o sonho nostálgico dela como 'um ninho enorme' num retiro campestre. No entanto, quem, como ele, busca a 'moderna e fina arte' nunca consegue escapar inteiramente no esquecimento inconsciente de qualquer estupor físico, como o 'bêbado feliz que fala só'. Pelo contrário, como o homem que ensina a filha a ler, o narrador, o artista, está empenhado na actividade de ensinar a ler que é parte integrante e, em relação à sua companheira, o propósito do poema.(...) O brutal desejo de violentá-la fisicamente que o invadiu foi sublimado na necessidade de lhe comunicar o seu diferente

\footnotetext{
${ }^{206}$ VERDE, Cesário, op.cit. p. 128.
} 
entendimento, que o poema registra, do passeio que deram juntos. O poema é, assim, dirigido à 'terrível criança' como um aviso, uma lição de leitura, e um adeus."207

\section{E ali começaria meu desterro! ...}

Lodoso o rio, e glacial, corria;

Sentámo-nos, os dois, num novo aterro

Na muralha dos cais da cantaria.

Nunca mais amarei já que não amas,

E é preciso, decerto, que me deixes!

Toda a maré luzia como escamas,

Como alguidar de prateados peixes.

E como é necessário que eu me afoite

A perder-me de ti por quem existo,

Eu fui passar ao campo aquela noite

E andei léguas a pé pensando nisto. ${ }^{208}$

A expressão "perder-me de ti por quem existo" completa a declaração anterior "nunca mais amarei já que não amas”. Este Eu, dessa forma, não só rompe os vínculos com a mulher inconsciente mas também consigo. Ele se perde também de si ao perdê-la, e no que pode parecer uma conseqüência inevitável entre consciências tão distintas - a mulher produto citadino e este $\mathrm{Eu}$ que recorre ao campo para se reconstituir - mostra também a inevitabilidade das relações entre este Eu artista e esta mulher 'iletrada'. Este crer na arte, no entanto, não eleva tanto este Eu a ponto de isolar-se de si mesmo. O meio e o tempo, mesmo vistos da confortável perspectiva do criador, são como o rio, lodoso, glacial, a levar tudo e a todos na sua corrente inexorável rumo ao mar das igualdades que só a morte democratiza. A arte como contraponto a esta morte é também o desterro deste artista, perdido daquela terra natal dos seus desejos e sonhos, incompatíveis com suas responsabilidades e consciência.

\footnotetext{
${ }^{207}$ MACEDO, Helder, op.cit, p. 160 e 163.

${ }^{208}$ VERDE, Cesário, p. 129.
} 
Em Petiz não há, literalmente, esta 'torre' onde o Eu pode se isolar. Ele é colocado lado a lado com a morte, e volta-se para um passado remoto, onde tenta se reconstituir da violência pela memória das andanças e da visão de vida que o campo lhe traz:

"Quando, na solidão, sonhando mais longamente, vamos para longe do presente reviver os tempos da primeira vida, vários rostos de criança vêm ao nosso encontro. Fomos muitos na vida ensaiada, na nossa vida primitiva. Somente pela narração dos outros é que conhecemos a nossa unidade. No fio de nossa história contada pelos outros, acabamos, ano após ano, por parecer-nos com nós mesmos. Reunimos todos os nossos seres em torno da unidade do nosso nome. Mas o devaneio não conta histórias. Ou, pelo menos, há devaneios tão profundos, devaneios que nos ajudam a descer tão profundamente em nós mesmos que nos desembaraçam da nossa história.Libertam-nos do nosso nome. Devolvem-no, essas solidões de hoje, às solidões primeiras. Essas solidões primeiras, essas solidões de criança, deixam em devaneio que sabe o preço da solidão. A infância conhece a infelicidade pelos homens. Na solidão a criança pode acalmar seus sofrimentos. Ali ela se sente filha do cosmos, quando o mundo humano lhe deixa a paz. E é assim que nas suas solidões, desde que se torna dona dos seus devaneios, a criança conhece a ventura de sonhar, que será mais tarde a ventura dos poetas." 209

Desta reconstituição, anterior e causada pelo impacto da violência do grito da companheira, o Eu recorda-se deste tempo intocado pela morte. Mas, a morte que poderia ser causada pelo elemento natural, no caso a 'vaquita preta', não causava tanto temor neste Eu do que os mendigos, os madriões, os pobres. A natureza era para este Eu, um lugar de vida:

Mais morta do que viva, a minha companheira

Nem força teve em si para soltar um grito;

E eu, nesse tempo, um destro e bravo rapazito,

Como um homenzarrão servi-lhe de barreira!

Em meio de arvoredo, azenhas e ruínas,

Pulavam para a fonte as bezerrinhas brancas;

E, tetas a abanar, as mães de largas ancas,

${ }^{209}$ BACHELARD, Gaston, Poética do devaneio, p 93-94. 
Desciam mais atrás, malhadas e turinas. ${ }^{210}$

Nesta natureza em que o Eu sente-se pleno de potência há outros habitantes que alteram a ordem harmoniosa: o leiteiro que batiza o leite e ainda tira o sono pelo grito, numa descrição que demonstra não só o 'desvirtuar' o alimento pelas mãos dos homens, mas também como este incomoda-se pela existência destes em meio ao seu recanto paradisíaco. Por isso, a solidão impossível ou a companhia desejada da "minha loura e doce como um bolo! / Afável hóspeda da nossa casa(...)" ${ }^{\text {,11 }}$ Nesta solidão, este Eu que recorda-se e comenta sua infância, dá-se o direito de tecer comentários que, este mesmo Eu, desconstruirá as sentirse triste pela forma como se lembra. Mas, precisamente, ao relembrar como se ali estivesse, sem os olhos do adulto consciente, consegue criticar não somente a si, mas o meio que o criou:

"Cesário estava obviamente consciente de que sua visão infantil do campo devia tanto a uma identificação acrítica com os valores da classe dominante em que tinha nascido como a identificação orgânica com o mundo natural do campo a que sentia pertencer. O poema estabelece assim, uma distinção fundamental entre o campo como realidade social e o campo como mito pessoal. A criança que confunde pobreza com maldade está simplesmente a reproduzir uma atitude tão obviamente injusta como a do patrão que, em 'Desastre' atribui a morte do ajudante pedreiro a 'alguma bebedeira', numa reacção que é, aliás, ela própria, um eco da atitude estereotipada da burguesia oitocentista sobre os 'vicíos' tradicionais dos pobres: sujidade, alcoolismo, desonestidade, preguiça, falsidade, etc.(...) Porque o que Cesário faz neste poema é destruir, por dentro, a visão convencional do campo sorridente e ameno que ele próprio tinha adoptado nos seus primeiros poemas. Começa assim a distinguir, dentro da sua lembrança pessoal, entre o campo como mito e o campo como realidade, um tema que vai desenvolver no seu último poema completo, 'Nós'.,’12

O mito pessoal deste campo também é um mito pessoal deste Eu. Neste lugar passado, das suas recordações, ele se sente "um destro e bravo rapazito" e "imenso contra as vacas", num à vontade neste natureza somente interrompia quando colocado defronte à miséria do povo que nela habita:

\footnotetext{
${ }^{210}$ VERDE, Cesário, op.cit, p. 131.

${ }^{211}$ Ibidem, p. 133.

${ }^{212}$ MACEDO, Helder, p. 136 e 137.
} 
Pois eu, que no deserto dos caminhos,

Por ti me expunha imenso contra as vacas;

Eu, que apartava as mansas das velhacas,

Fugia com terror dos pobrezinhos!

Vejo-os no pátio ainda! Ainda os ouço!

Os velhos que nos rezam padres-nossos;

Os mandriões que rosnam, altos, grossos;

E os cegos que se apóiam sobre o moço. ${ }^{213}$

A impressão causada pelo terror dos pobres ainda ecoa neste Eu. Bergson comentará:

"Mas como o passado, que por hipótese, cessou de ser, poderia por si mesmo conservar-se? Não existe aí uma contradição verdadeira? - Respondemos que a questão é precisamente se o passado deixou de existir, ou se ele simplesmente deixou de ser útil. Você define arbitrariamente o presente como o que é, quando o presente é simplesmente o que se faz. Nada é menos que o momento presente, se você entender por isso esse limite indivisível que separa o passado do futuro.(...) Para que uma lembrança reapareça à consciência, é preciso com efeito que ela desça das alturas da memória pura até o ponto preciso onde se realiza a ação. Em outras palavras, é o de presente que parte o apelo ao qual a lembrança responde, e é dos elementos sensórios motores da ação presente que a lembrança retira o calor que lhe confere vida."214

A ação que se propõe este Eu, é, por um lado, lembrar-se sem influir no passado, tal qual suas sensações o recordam, mas por outro, antagonicamente, é tentar se reconstituir através do comentário que faz à essas mesmas sensações da infância. Por isso, tal passado mostra-se útil para a constituição presente: a reconstituição que pode parecer maldosa não é velada, mas ao contrário, é exposta cruelmente por este Eu, que, ao assumir serem comentário de uma criança, tornam-no ainda mais cruel:

Aos sábados, os monstros que eu lamento,

\footnotetext{
${ }^{213}$ VERDE, Cesário, p. 132

${ }^{214}$ Henri Bergson, Matéria e Memória, p. 177 e 179.
} 
Batiam ao portão com seus cajados;

E um aleijado com os pés quadrados,

Pedia-nos de cima de um jumento.

O resmungão! Que barbas! Que sacolas!

Cheirava a migas, a bafio, a arrotos;

Dormia as noites por teheiros rotos,

E sustentava o burro a pão de esmolas. ${ }^{215}$

O comentário ‘eu lamento' deste Eu parece pôr um fim, definitivamente, não somente àquela Arcádia que nos fala Helder Macedo, mas também a possibilidade que este Eu depositava na ventura dos poetas, naquele momento solitário irmão da ventura da infância, em que o significado e o significante são ainda coincidentes e este mesmo Eu, ainda encontra-se na unidade da inocência. $\mathrm{O}$ comentário que faz aos artistas despedidos, desgraçados e à Camões morrendo na miséria reforçam essa idéia do ideal que se perde antes mesmo de se firmar. A arte, o momento de solidão inocente, já é e era maculado, tal qual o leite, mas não somente pelo meio, mas também por este Eu que se percebe forte apenas para a lida com o gado, mas não consigo:

Uns operários, nestes descampados,

Também surdiam, de chapéu coco,

Dizendo-se, de olhar rebelde e louco,

Artistas despedidos, desgraçados.

Muitos! E um bêbedo - o Camões - que fora

Rico, e morreu a mendigar, zarolho,

Com uma pala verde sobre um olho!

Tivera ovelhas, bois, mulher, lavoura. ${ }^{216}$

Como este Eu vê o campo(ou via)e seus constituintes como um lugar de asceticismo pessoal, a ironia a Camões faz sentido. Assim como o bardo, este Eu também se vê

${ }^{215}$ VERDE, Cesário, p. 133
${ }^{216}$ Ibidem, p. 134. 
definitivamente perdido. Se nos poemas no primeiro capítulo vemos a importância da mulher para o acordo do Eu consigo mesmo, o fato de Camões ter tido tudo que seria necessário para sentir-se pleno adquire significado ainda mais claros de como este Eu se vê impossibilitado de estar em harmonia consigo. Temos o mito pessoal, seu lugar de fuga e constituinte primeiro de sua 'persona' batizados, e também o querer ser social em ruínas, pois o fazer artístico não o salva, nem enquanto personagem, nem enquanto Eu-lírico das mazelas e sequer como autor:

"Ao reintegrar os factos reais da sociedade rural na visão idealizada do campo arcádico, Cesário estava a fazer uma crítica moral profunda e radical não só dessa falsa visão mas também da classe social cujos valores essa visão refletia. Com efeito, 'Em Petiz' continha qualquer coisa de gravemente ofensivo para a ordem social estabelecida é confirmado pela reacção escandalizada que a sua publicação provocou. O 'Diário Ilustrado', porta-voz dessa reacção, foi ao ponto de imputar a Cesário o tipo de atitude que o poema tão eloquentemente ataca: 'Cada verso é simplesmente um vomitório, e cada recordação revela de sobejo os maus instintos da criança, e presentemente o desamor do homem já feito, pela desgraça e miséria alheias. O Sr. Verde, que é rico, e quer ser poeta, em vez de tirar da sua burra uma esmola e da sua bandurra palavras de conforto para os infelizes, arremessa-os esfarrapados e nus às colunas dum jornal enchendo-os de sacarmos e apupos! Excelente inspiração e bela índole! 217

Em Sentimento dum Ocidental, Cesário parece ter sido particularmente feliz ao produzir através das visões de um eu-lírico fragmentado, os "sentimentos" do homem ocidental finissecular. Sentimentos entendidos aqui, e melhor sintetizado por Fernando Pessoa, quando através de Ricardo Reis, determina: “A poesia é superior à prosa porque exprime, não um grau superior de emoção, mas, por contra, um grau superior do domínio dela, a subordinação do tumulto em que a emoção naturalmente se exprimiria(...)ao ritmo, à rima, à estrofe" 218 .

Permanência! "Se eu não morresse, nunca! E eternamente/ Buscasse e conseguisse a perfeição das cousas!”. Há em diversos momentos do poema a noção do criar artístico; noção esta que ultrapassa a constatação da arte em si e assume importância capital: é

\footnotetext{
${ }^{217}$ H. Macedo, pp. 137.

${ }^{218}$ PESSOA, Fernando. Obras completas.
} 
como se só a arte permanecesse e justificasse a vivência e o fazer artístico assume ares de tal importância que se diria um poema dentro de outro: ou da fragmentação do sujeito, a que se personaliza tocada pelo devir, por um resquício de esperança.

Mais do que definir, sugestionar: através de uma técnica já inovadora, o foco ou o ponto de vista, desloca-se tanto do sujeito quanto para o objeto; a apreensão do ambiente passa tanto pela coisa em si quanto pelos olhos do eu-lírico, num vai-e-vem (ou cortes cinematográficos) constante, rápido e ininterrupto. É que a particularidade da sensibilidade de quem conta ou daquilo que se revela através do comum, integra à todos na ação. As sugestões e as impressões que o Eu expressa, formam a base para o entendimento do que via não só nos homens de Linda-a-Pastora, da Travessa da Assunção ou de Lisboa, mas sim no Homem em geral. Literalmente fala-se daqueles à beira do Tejo, mas a metonímia já se revela clara; falase da parte pensando no todo; fala-se do "eu", do indivíduo, para tratar do Homem. E tal efeito não se situa apenas na palavra. Assim demonstra Helder Macedo: "os seus poemas progridem numa série de seqüências aparentemente acidentais de acontecimentos justapostos cuja articulação, estruturalmente metonímica, está mais próxima da técnica cinematográfica de corte e montagem (derivada da técnica de justaposição significativa do romance realista) do que da técnica poética de associação metafórica". 219

Essa técnica já pode ser vista no "corte" que se inicia com o segundo quarteto: da subjetividade do Eu passa-se para o ambiente onde ele está inserido. O poema demonstra então que o meio, no caso a cidade, atinge o individuo, mas este também molda o meio, através dos seus sentidos e de sua sensibilidade, "recriando-o. Nesse binômio, está claro, a parte principal cabe ao subjetivo, isto é, a emoção da coisa está antes e acima da coisa. Por isso, o céu parece "baixo e de neblina" e ao redor, a cor é "monótona e londrina".

O primeiro quarteto d“'O Sentimento Dum Ocidental, demonstra já no primeiro verso duas temáticas recorrentes: "nossas ruas", ou mais entendido como a cidade artificial, em contraposição à natureza, e a noite. No que refere-se à noite, e seu símbolo maior, a Lua, Joel Serrão bem escreve: “(...)perde terreno(a lua) em confronto com a luz do gás.A lua, símbolo da noite natural dos campos e da cidade, anterior à iluminação a gás e elétrica, impõe-se agora menos imperiosamente a partir do momento em que os homens lograram iluminar a superfície

\footnotetext{
${ }^{219}$ MACEDO, Helder, Nós.
} 
da terra onde vivem em comum." 220 . E sente o Eu tal perda, a ponto de reclamar e notar somente que "O gás extravasado enjoa-me, perturba;" e "A noite pesa, esmaga".

No pensar de Joel Serrão, a luz elétrica deveria ser um marco a favor do homem:

"Elo de uma multimilenária cadeia de esforços tendentes a desterrarem a noite dos lares, das ruas e da própria mente, a luz elétrica permitiu prolongar o trabalho fabril e domiciliário para além do fim do dia, consoante nosso bel-prazer ou nossas necessidades, e só isso, se fosse só isso, bastaria para atribuirmos a maior importância ao sucesso. Mas há mais: cremos que ela também significou um ponto marcado na luta contra o Medo (com maiúscula, por favor!), um medo quase estrutural que vem do fundo dos tempos. Medo da fome, das trevas e da morte - gerador de guerras, mitos e de apelos angustiados....221.

Mas para o Eu, isso significou perder a natureza, e de certa forma como se via tal natureza. A relação com a noite torna-se então doentia, e aquilo que o homem cria para si, volta-se contra ele mesmo: "Longas descidas! Não poder pintar/ Com versos magistrais, salubres e sinceros, / A esguia difusão dos vossos revérberos, / E a vossa palidez romântica e lunar!”.No que se refere à noite, e seu símbolo maior, a Lua, Joel Serrão escreve: “(...) perde terreno (a lua) em confronto com a luz do gás. A lua, símbolo da noite natural dos campos e da cidade, anterior à iluminação a gás e elétrica, impõe-se agora menos imperiosamente a partir do momento em que os homens lograram iluminar a superfície da terra onde vivem em comum" 222 . E sente o Eu tal perda, a ponto de reclamar e notar somente que "O gás extravasado enjoa-me, perturba"; e "A noite pesa, esmaga".

É esse o espaço e momento que o eu encontra a soturnidade e a melancolia. A soturnidade como uma sensação externa, ou seja, qualidade própria de um objeto, e a melancolia como sensação do sujeito, conseqüentemente interna, são percebidas enquanto sensações pela visão (“as sombras”), pela audição (“o bulício"), pelo olfato ("a maresia"), mas também pela inteligência (o denominar o rio como Tejo). Estamos vendo aquilo que Charles Baudelaire em "Correspondências" de Flores do Mal, chama de relação entre o mundo

\footnotetext{
${ }^{220}$ SERRÃO Joel, Temas Oitocentistas I.

${ }^{221}$ Ibidem.

${ }^{222}$ Ibidem.
} 
material e o espiritual, ou mais claramente, das relações entre o mundo concreto e o abstrato e da fusão das diferentes sensações no mundo material, as chamadas sinestesias. Fusão esta, que Álvaro Cardoso Gomes define como:

(...) um esforço para recuperar a linguagem original, aquela em que a palavra, mais do que simples representação dos objetos é também coisa ela própria. Trabalhando com imagens sinestésicas, o poeta deseja representar o instante da percepção de um objeto, de um movimento, sem a incômoda intervenção da inteligência, que tende a separar as sensações em blocos distintos. (...) Encontrada a correspondência entre os sentidos, ainda segundo Baudelaire, o homem está apto a participar do mundo da Natureza, em que todas as coisas têm íntima relação entre si, em que o mundo material não está de modo algum dissociado do espiritual. ${ }^{223}$

Aqui, nota-se que o texto de Cesário faz dois adendos: separa sim, as sensações utilizando as vírgulas, já que o eu-lírico irá proclamar mais adiante, como uma confissão da impossibilidade do desregramento de todos os sentidos pelo apego ao logos ("E eu que medito um livro que exarcebe, quisera que o real e a análise mo dessem...”) e não concede o espiritual: ("Enleva-se a quimera azul de transmigrar".). A evocação do Tejo, nesse sentido, tanto quebra o "puro sentir" quanto mantém os olhos no material, em detrimento de uma possível leitura metafísica. Se afasta o Eu do ideal simbolista o manter-se à tona e não mergulhar nas sensações puras para tentar descobrir a essência das coisas, o manter os olhos no racional e dar as sensações um prolongamento que seja explicativo (O Tejo) o aproxima de um quase sensacionismo, à lá Pessoa.

Se sofre o Eu com um desejo absurdo de sofrer, um dos motivos é por aquilo considerado essencial para ser português: o mar. E não é de um português que se fala? Sim, textualmente fala-se daqueles à beira do Tejo, mas a metonímia já se revela clara; fala-se da parte pensando no todo; fala-se do "eu", do individuo Não só a literatura, mas o próprio povo sempre tratou o mar como algo a ser navegado, descoberto e reinado pelo português, e esse descobrir e aventurar (mas principalmente o reinar) o mar sempre foram o "norte" de Portugal. Este $\mathrm{Eu}$, porém, vê que aquela grandeza já não existe mais, ou pelo menos o cantar "romântico", épico, já não é mais possível no seu tempo, pois por terra, de forma segura se vai

${ }^{223}$ GOMES, Álvaro Cardoso, A Estética Simbolista. 
ao mundo, bastando para isso poder pagar. Mas quem pode pagar? Quem pode escapar dessa prisão que a cidade se constitui? Não certamente as costureiras, as floristas, as varinas ou ainda os emigrados. A eles, que constitui o povo que labuta, só resta sofrer... Chama a atenção também, e torna-se outra chave para a leitura da obra cesariana a noção de que a "felicidade" está com aqueles que vão, ou seja, aqueles que estão em movimento, passando de um estado para outro, e tal sentimento está situado e permanece enquanto durar tal ação. Por isso o "Felizes!", destacando-se da frase e do contexto pelo ponto final que o precede e pela exclamação. É um estado, tal como se lê, isolado, curto e explosivo. A bem da verdade, são felizes porque o estar em movimento distrai o sujeito de si e o força a olhar o externo:

Batem os carros de aluguer, ao fundo,

Levando à via-férrea os que se vão. Felizes!

Occorrem-me em revista, exposições, países:

Madrid, Paris, Berlim, S. Petersburgo, no mundo!

Prova textual maior de que o criar humano, visto como a inovação técnica volta-se contra o homem é o quarteto: "E eu desconfio, até, de um aneurisma/ Tão mórbido me sinto, ao acender das luzes; / À vista das prisões, da velha Sé, das Cruzes, / Chora-me o coração que se enche e que se abisma”.Mas há duas outras criações humanas que também o levam a sentirse mórbido, pesado e em queda: a religião e a História. Os prédios, as igrejas, os monumentos relembram e despertam um passado glorioso que nunca mais voltará, e isso causa uma dor ainda maior no sujeito. Dor que acrescida da consciência de um espectador que sabe que as construções imaginadas para celebrar a engenhosidade humana, e certamente a cidade é o melhor exemplo, tornam-se túmulos não só de ideais impossíveis como do próprio ser humano: "E eu sonho o Cólera, imagino a Febre, / Nesta acumulação de corpos enfezados; / Sombrios e espectrais recolhem os soldados: / Inflama-se um palácio em face de um casebre". E sofre ainda mais o Eu pela constatação de que, aquilo que o faz sofrer também o atrai. Como uma amante de pedra e madeira, confessa a sua atração, o seu amor impossível: "Triste cidade! Eu temo que me avives/ Uma paixão defunta! Aos lampiões distantes, /Enlutam-me, alvejando, as tuas elegantes, Curvadas a sorrir às montras dos ourives”.

O Sentimento dum Ocidental é o definitivo divórcio deste Eu não só com a cidade, mas também com a infrutífera busca pelo concerto através do meio. Compreender este meio, 
apreender e, por fim, poetiza-lo, seria uma tentativa de nele se diluir e nele se encontrar. Se, sabedor de que, somente por si e dentro de si não há harmonia, e, a busca do cotidiano e da temporalidade poderiam ajusta-lo ao mundo e principalmente consigo, este poema torna-se o obituário do Eu que observa, mas não ainda do Eu que poetiza. Este último recurso, o poema, ainda desperta um resquício de esperança para sua constituição. Por isso, os versos:

E evoco, então, as crônicas navais:

Mouros, baixéis, heróis, tudo ressuscitado!

Luta Camões no Sul, salvando um livro a nado!

Singram soberbas naus que eu não verei jamais ${ }^{224}$

E eu que medito um livro que exarcebe, Quisera que o real e a análise mo dessem; $;^{225}$

Longas descidas! Não poder pintar Com versos magistrais, salubres e sinceros, ${ }^{226}$ (...)

E eu sigo, como as linhas de uma pauta A dupla correnteza augusta das fachadas; Pois sobem, no silêncio, infaustas e trinadas, As notas pastoris de uma longíqua flauta.

Se eu não morresse, nunca! E eternamente Buscasse e conseguisse a perfeição das cousas! Esqueço-me a prever castíssimas esposas, Que aninhem em mansões de vidro transparente! $!^{227}$

${ }^{224}$ Ibidem, p. 150.

${ }^{225}$ Ibidem, p. 153.

${ }^{226}$ Ibidem, p. 153

${ }^{227}$ Ibidem, p. 155 
Porém, como dito, são resquícios de uma vã esperança que o próprio Eu parece tentar destruir com os comentários que faz sobre as notas pastoris, longínquas e as castíssimas esposas. Este $\mathrm{Eu}$, volta-se àquilo que anteriormente já sentiu como sendo parte daquele desconcerto que existia dentro de si e que buscou apaziguar ao olhar com outros olhos sua relação com o Outro, e também ao sair de suas lucubrações amorosas. Aquele mergulho ao inconsciente, ao seu Eu mais profundo, deram lugar a analise do real, mas este mesmo real, que desperta o desejo de sofrer, não mais pode ser simplesmente pintado, o que coloca este Eu definitivamente deslocado de qualquer posição: ele é o "qualquer coisa de intermédio", mas não como gostaria: enquanto artista. Assim, quando ao visualizar o fim de sua função enquanto constituinte deste mundo, o que vê é o quadro da dor, que torna-se a Dor humana a buscar amplos horizontes:

\section{E, enorme, nesta massa irregular}

De prédios sepulcrais, com dimensões de montes,

A dor humana busca os amplos horizontes,

E tem marés, de fel, como um sinistro mar! ${ }^{228}$

Deste mar, ao contrário daquele de Heroísmos, este Eu não pode rir, pois sabe que a dor que cobre tudo, sai dele e vem do meio para ele. Ele já carrega dentro de si o sepulcro que o meio, finalmente, impossível de ser poetizado, o abate. Este sentimento, no poema De Verão, será suavizado pela fuga ao campo, última fuga também já que em Nós o campo não mais é sua Arcádia, e sim encontra a utilidade que espanta o poeta. Porém, De Verão, este Eu se tenta se reanimar:

No campo; eu acho nele a musa que me anima:

A claridade, a robustez, a acção.

Esta manhã, saí com minha prima,

Em quem eu noto a mais sincera estima

E a mais completa educação. ${ }^{229}$

\footnotetext{
${ }^{228}$ Ibidem, p. 156.

${ }^{229}$ Ibidem, p. 158.
} 
Esta fuga não recobra a confiança do Eu naquele fazer artístico. É, simplesmente, uma fuga e a constatação que não pode fugir mais de si. A cidade, aquele meio que serviu para sua tentativa de constituição, está nele:

\section{Criança encantadora! Eu mal esboço o quadro}

Da lírica excursão, da intimidade.

Não pinto a velha ermida com seu adro;

Sei só desenho de compasso e esquadro,

Respiro indústria, paz, salubridade. ${ }^{230}$

Saber desenhar somente de compasso e esquadro é uma declaração que mostra o quanto este Eu já também se vê um tecnocrata, diferente do artista que pintaria a lírica excursão. Ele ali está e não está: fisicamente se põe no campo, mas sabe-se já um homem citadino. A condição campestre leva a ambos, este Eu e a mulher a notarem suas diferenças. Ele, declaradamente, respira indústria. Ela, num à vontade, mistura-se ao campo e nele se integra:

\section{Andam cantando aos bois; vamos cortando as leiras; \\ E tu dizias: 'Fumas? E as fagulhas? \\ Apaga o teu cachimbo junto às eiras; \\ Colhe-me uns brincos rubros nas ginjeiras! \\ Quanto me alegra a calma das debulhas! 231}

A diference entre eles é de também de caráter. Ela é "austera, gentil, a inteligente", enquanto ele é "ocioso, inútil, fraco." Mas é também pela constatação que este Eu não mais pertence àquele lugar. Ele não é mais o romântico e sim o feroz. Sente-se como um Werther, a lamentar a perda do sentimento da natureza ${ }^{232}$, da unidade que, se não com o Universo, ao

\footnotetext{
${ }^{230}$ VERDE, Cesário, op.cit, p. 158

${ }^{231}$ Ibidem, p. 158.

232 “O sentimento cabal, fervoroso do meu coração pela Natureza completa da vida que se inundava de infindáveis deleites, que transformava o mundo que me cerca num paraíso, está-se convertendo para mim num verdugo insuportável, num espectro atormentador que me persegue por todos os caminhos. Quando, outrora, contemplava de um rochedo o fértil vale que, além do rio, se estendia até as colinas e via tudo em redor a germinar e a desabrochar; (....)Tudo, tudo repleto de milhares de formas; e os homens, depois, protegendo-se juntos em arremedos de casas e, em pensamento, reinando sobre o vasto Universo! Pobre louco, que consideras tudo tão insignificante, sendo tu tão ínfimo(...)" Goethe, Sofrimentos do jovem Werther.
} 
menos consigo, e por isso se enfurece com um bando de formigas. Esta raiva parece muito com o sentimento de desdém que nutria no poema Em Petiz. As ladras agora são as formigas, e, cheio de uma potência relativa, declara:

\section{“As ladras da colheita! Eu, se trouxesse agora \\ Um sublimado corrosivo, uns pós \\ De solimão, eu, sem maior demora, \\ Envenená-las-ia! Tu, por ora, \\ Preferes o romântico ao feroz. ${ }^{233}$}

Após esse breve desatino, o Eu cala-se após a visão da companheira. "Os seus comentários sarcásticos caem no silêncio e lentamente começa a ver a rapariga transfigurada numa jovem Ceres de cabelos cor de trigo ${ }^{234}$. Nesta belíssima estrofe, a totalidade da Natureza é significada através das subtis associações que estão na base da visão transfiguradora que subliminalmente sugerem: os verdes prados fundem-se com o mar fosforescente; o luzir 'honesto' do cabelo loiro prolonga-se na cor do trigo amontoado nos calcadoiros.,"235

\section{E enfim calei-me.Os teus calos muito loiros}

Luziam, com doçura, honestamente;

De longe o trigo em monte, e os calcadoiros,

Lembravam-se fusões de imensos oiros,

E o mar um prado verde e florescente. ${ }^{236}$

Chama a atenção Helder Macedo para a ironia do "feroz narrador(que) finalmente sucumbe à visão romântica do campo" ${ }^{237}$, mas ao final, a mulher é quem se torna a feroz ${ }^{238}$ :

“Não me incomode, não, com ditos detestáveis!

Não seja simplesmente um zombador!

Estas mineiras negras, incansáveis,

\footnotetext{
${ }^{233}$ VERDE, Cesário, op.cit, p. 161.

${ }^{234}$ Helder Macedo esclarece que foi Stephen Reckert quem notou esta sutil metamorfose.

${ }^{235}$ MACEDO, Helder, op.cit p. 143.

${ }^{236}$ VERDE, Cesário, op.cit, p. 161.

${ }^{237}$ MACEDO, Helder, op.cit,p. 143.

${ }^{238}$ Helder Macedo chama de romântico o campo como musa e feroz o campo como trabalho.
} 
São mais economistas, mais notáveis,

E mais trabalhadoras que o senhor!",239

Esta inversão de papéis, já dita irônica, também possibilita aventar-se à idéia de que, este Eu e este Outro estão separados não somente pelo caráter, mas distanciados também pelo tempo. O momento de um não coincide com o do outro: na verdade, mesmo compartilhando do mesmo campo, ele se põe atrás dela, só aproximando-se novamente quando a companheira dá um salto:

E, como quem saltasse, extravagantemente,

Um rego de água sem se enxovalhar,

Tu, a austera, a gentil, a inteligente,

Depois de bem composta, deste à frente

Uma pernada cósmica, vulgar!

Exótica! E cheguei-me ao pé de ti. Que vejo!

$$
(\ldots)^{240}
$$

Neste contexto, as qualidades da mulher podem ser vistas de forma irônica. Ela, a "austera, a gentil, a inteligente", também tem momentos menos austeros, menos inteligentes, menos gentis. Mas ainda é superior ao $\mathrm{Eu}$, e neste descarrega sua ferocidade. $\mathrm{O}$ momento romântico deste $\mathrm{Eu}$, romântico também em relação à mulher que desperta seus sentidos é exatamente interrompido por ela:

\section{$X V I$}

Vibravam, na campina, as chocas da manada;

Vinham uns carros a gemer no outeiro,

E finalmente, enérgica, zangada,

Tu inda assim bastante envergonhada,

Volveste-me, apontando o formigueiro:

${ }^{239}$ VERDE, Cesário, op.cit, p. 162.
${ }^{240}$ Ibidem, p. 160. 
“Não me incomode, não, com ditos detestáveis!

Não seja simplesmente um zombador!

Estas mineiras negras, incansáveis,

São mais economistas, mais notáveis,

E mais trabalhadoras que o senhor! "241

Aceita a bronca, este Eu, ao constituir-se como personagem antagônica de um Outro superior que sente-se à vontade num paraíso que era dele, ressalta ainda mais a sua condição de perdido e deslocado. Ela é uma criança, diferente da criança que ele foi Em Petiz, intocada ainda pelo mundo que já não o permite ser tão inocente e tão romântico.

Em Nós, o último poema completo de Cesário Verde, o Eu definitivamente conclui não haver concerto para a sua condição. $\mathrm{O}$ mundo ao seu redor é caos; seu Eu perante à si também é caos, e, sua tentativa de se restituir perante aos seus próprios olhos pela arte, mostrase impossível. Se a arte, para este $\mathrm{Eu}$, concertaria um mundo desconcertado, como pode concertar a si mesmo, se sua arte é fruto da visão de um Eu desconcertado? Por isso, os versos finais deste poema, são seu epitácio:

E agora, de tal modo a minha vida é dura,

Tenho momentos maus, tão tristes, tão perversos,

Que sinto só desdém pela literatura, E até desprezo e esqueço os meus amados versos! $!^{242}$

Mas como poderia este Eu querer pintar este mundo? O poema é dividido em três partes: a primeira, mostra a cidade e o estado de calamidade que ali se instaura. As doenças matam aos milhares, e o desespero causa ainda mais morte. Aquela cidade do Bairro Moderno arde em chamas; desaparece dos olhos do Eu-poeta o sol e só resta a morte e seus sinais. A segunda, o campo paradisíaco também não evita que a morte, no seio de sua família, aconteça. A fartura e a harmonia não suavizam as doenças, e a distância da cidade não afasta a peste. Na terceira parte, de volta a cidade, este Eu, na sua última tentativa de se constituir, de evitar seu

\footnotetext{
${ }^{241}$ Ibidem, op.cit,p. 162.

${ }^{242}$ Ibidem, p. 184.
} 
desmoronamento, ainda pensa em recorrer a sua arte, mas a morte de outro irmão vaticina seu desencanto do mundo.

A primeira parte do poema, divididos por numerais romanos, é uma rememorização de um passado relativo à segunda parte do poema, a mais longa das três, com 111 quadras, que por sua vez é um passado imediato da última parte, que se constitui numa espécie de presente em que o Eu escreve o poema. Nesta primeira parte, temos já na primeira quadra a imagem do caos que a urbs se tornou, e, em seis das doze quadras, o quadro terrível se estende à todos que não fugiram:

Foi quando em dois verões seguidamente a Febre

E o cólera também andaram na cidade, Que esta população, com um terror de lebre,

Fugiu da capital como da tempestade. ${ }^{243}$

Se acaso o conta, ainda a fronte se lhe enruga:

O que se ouvia sempre era o dobrar dos sinos;

Mesmo no nosso prédio, os outros inquilinos

Morreram todos. Nós salvámo-nos na fuga. ${ }^{244}$

A percepção que se têm ao ler as descrições é que há dois momentos antagônicos: o da morte e o da vida. A morte é representada e qualificada por verbos que a antropormofizam, como quando são descritas as doenças ("a Febre E o Cólera também andaram na cidade”), as seges dos enterros ("Rodavam sem parar a sege do enterro"), os dejetos ("Secavam dejecções cobertas de mosqueiros"), em contraste aos homens, que fogem com um "terror de lebre". Esse mesmo processo de antropormofização é usado para se falar da vegetação, que, graças a "enorme mortandade", crescia potente:

Porém, lá fora, à solta, exageradamente,

Enquanto acontecia essa calamidade,

Toda a vegetação, pletórica, potente,

${ }^{243}$ Ibidem, p.163

${ }^{244}$ Ibidem, p. 163. 


\section{Ganhava imenso com a enorme mortandade!}

Num ímpeto de seiva os arvoredos fartos,

Numa opulenta fúria as novidades todas,

Como uma universal celebração de bodas,

Amaram-se! E depois houve soberbos partos. ${ }^{245}$

O último verso traz uma importante idéia: a vida, aqui representada pela vegetação, cuida de se prolongar, mas só na ausência do homem. Este mesmo homem, que foge como uma lebre, é, neste contexto, apenas um acidente deste complexo processo de morte e vida. De fato, a morte e a vida são elementos que se tornam opostos apenas em relação a este homem. É a temporalidade, a mortalidade deste que os separa em dois momentos: é a visão de vida e morte que faz com que conheça sua morte e consequentemente sinta o que é a vida, ao fim, apenas um intervalo ligado à noção da morte.

As fugas para o campo, aonde vão os "provincianos/ desde o calor de maio aos frios de novembro", somada a visão do pai que, "dum lado, via os filhos achacados,/ Um lívido flagelo e uma moléstia horrenda!/ E via, do outro lado, eiras, lezírias, prados,/ E um salutar refúgio e um lucro na vivenda!", demonstra também que, para este eu, que de fato, literalmente só parece numa quadra, ao dizer que: "E o campo, desde então, segundo o que me lembro,/É todo o meи amor de todos esses anos", condiciona sua existência aos desígnios do meio. Deste meio, enquanto agente, vê o refugio e o lucro, e é dessa noção de utilidade que surge o amor deste Eu. Assim, aquele campo lúdico, o "paraíso perdido", não mais existe para este Eu. Ele se faz, ou ele se deixa fazer, tomado por esse terror de lebre, ou naquele barco perdido no mar de Heroísmos e ou o homem que desdenhava e cuspia.

Por essa visão, pode-se compreender que, a visão que tem do campo, na segunda parte, é fortemente marcada pela noção de utilidade. Considerando as marcas gráficas de separação interna desta seção (as 'estrelas'), como separações de momentos temporais distintos, e conseqüentemente rupturas psicológicas nesse ato de rememorização, temos no primeiro momento, os verbos no presente (“Em que o sol, nos talhões e nas latadas,/ Bate de chapa, logo de manhã!" ou "O laranjal de folhas negrejantes(...)Desce em socalcos todos os 
maciços"). A construção das frases com esse recurso, ligando tais verbos de ação à natureza, ressalta aquilo que foi dito anteriormente, da existência enquanto um ente desta natureza, e também dá um caráter de perene a esta mesma natureza. Em contraponto, temos o homem, atuando enquanto limitador do poder desta natureza e agente em nome da morte:

Contudo, nós não temos na fazenda

Nem uma planta só de mero ornato!

Cada pé mostra-se útil, é sensato,

Por mais finos aromas que rescenda!

Finalmente, na fértil depressão,

Nada se vê que a nossa mão não regre:

A florescência dum matiz alegre

Mostra um sinal - a frutificação! $!^{246}$

Se forem a Febre e o Cólera analogias da morte, não se pode deixar de ressaltar que são apenas em relação ao homem. Com a ausência deste homem na cidade, a vegetação pôde aflorar. E é a mão desse homem, neste momento, que transforma harmonia em utilidade. $\mathrm{O}$ campo, perene, vive por si, harmonicamente. A presença desse homem, porém, modifica as regras: planta-se apenas o que é útil; cepa-se o que é mero ornato. E é este $\mathrm{Eu}$, portador da morte, que, a partir da morte da irmã, começa a questionar sua própria existência. A irmã é compara a uma flor: "Unicamente, a minha doce irmã,/ Como uma tênue e imaculada rosa" e "nós perdemos essa flor precocemente". Há aí, sem dúvidas, provado por essa analogia, um sentimento de culpa. Anteriormente, declara-se que tudo que é de ornato é regrado, decepado para dar lugar ao útil. A imagem da irmã como uma flor que morre é correlacionada àquela harmonia que a presença humana desestabiliza. A utilidade então é vista como daninha:

Ai daqueles que nascem neste caos,

E, sendo fracos, sejam generosos!

As doenças assaltam os bondosos

E-custa a crer-deixam viver os maus. $!^{247}$

\footnotetext{
${ }^{246}$ Ibidem, p. 167.

${ }^{247}$ Ibidem, p. 168.
} 
A visão daquele campo benéfico, apto a ser utilizado por este homem, entra em contradição: agora é caos. E a queda desta crença, que custa a crer, na força que provem da engenhosidade do homem, torna-se o tema a partir desta morte de discussão. A engenhosidade que serve tão somente ao lucro, ao dinheiro, é colocada em questão nas quadras seguintes. Porém, notadamente, este $\mathrm{Eu}$, num exercício cansativo, rememora sua irmã em plena atividade, dando-lhe vida nas "telas da memória retocadas". Neste ponto, há ainda o crer no processo artístico enquanto perpetuador de si, de suas memórias, de sua constituição. Nota-se o momento de reflexão, pelo fechar dos olhos e de isolamento:

Fecho os olhos cansados, e descrevo

Das telas da memória retocadas,

Biscates, hortas, batatais, latadas,

No país montanhoso, com relevo!

Ah! Que aspectos benignos e rurais

Nesta localidade tudo tinha,

Ao ires, com o banco de palhinha,

Para a sombra que faz nos parreirais!

Ah! Quando a calma, à sesta, nem consente

Que uma folha se mova ou se desmanche,

Tu refeita e feliz com o teu "lunch"

Nos ajudava, voluntariamente!... ${ }^{248}$

Nesses versos, nota-se que o processo de rememorar permite um solilóquio entre este Eu e sua irmã, e permite também uma espécie de pedidos de desculpas, pelo entendimento da culpa reconhecida:

À procura da libra e do "shilling”,

Eu andava abstrato e sem que visse

Que o teu alvor romântico de "miss"

${ }^{248}$ Ibidem, p. 168. 
Te obrigava a morrer antes de mim! ${ }^{249}$

Entretanto, nota-se que faz nos versos seguintes não só um mea culpa mas inicia uma apologia sobre a força que provêm deste campo. Ela, como típica citadina, habitante desta $u r b s$, não soube se aproveitar desta força; em parte por causa dos hábitos artificiais adquiridos na cidade por esta burguesia, em parte pela vaidade feminina:

E antes, $t u$, ser lindíssimo nas faces

Tivesse "pano" como as camponesas;

E sem brancuras, sem delicadezas,

Vigoroza e plebéia, inda durasses!

Uns modos de carnívora feroz.

Podias ter em vez de inofensivos;

Tinhas caninos, tinhas incisos,

E podias ser rude como nós! $!^{250}$

Há de se notar, para o entendimento de posterior explicação, o fato deste Eu nomearse "nós". Aqui, pode-se ver desde já, que ele se coloca na posição de "carnívoro". Ele, o homem útil, devora o que necessita para sua sobrevivência. Mas também ao se denominar nós, e, nos versos seguintes se contrapor à ingleses e à Europa do Norte, demonstra o sentimento de sua terra. Esta terra, Portugal, retira sua força do campo e não da indústria:

Sim! Europa do Norte, o que supões

Dos vergéis que abastecem teus banquetes,

Quando às docas, com frutas, os paquetes

Chegam antes das tuas estações?! 251

A abrupta afirmativa "Sim!" que inicia a série de apóstrofes implicando o retomar de uma idéia anterior - sugere uma relação profunda e decisiva entre a morte da irmã do poeta, explicada como o resultado da sua inadequação ao

\footnotetext{
${ }^{249}$ Ibidem, p. 169

${ }^{250}$ Ibidem, p. 170.

${ }^{251}$ Ibidem, p. 170.
} 
meio, e o tema do progresso que vai ser desenvolvido através das apóstrofes aos representantes significativos da ordem impugnada. Dirigindo-se num tom familiar e de desafio à "Europa do Norte", o poeta começa por expor as inadequações do mundo artificial da indústria em contraste com o mundo natural do Sul de Portugal. É com base neste contraste que os pólos semânticos cidade e campo são amplificados para incluírem a nova dualidade entre Norte e Sul. ${ }^{252}$

Como entender, porém, se até então este Eu se colocava como um homem útil, a crítica que faz à Inglaterra e suas indústrias? A utilidade não é ligada somente à cidade e à indústria. Como visto, seria a capacidade de se adaptar ao meio, ou adaptar o meio ás suas necessidades e desejos. É essa capacidade que retira da terra a energia para a vida, capacidade esta que os versos sobre os ingleses e suas cidades industrias demonstra inexistir nestes. Por isso, são "ricos suicidas", já que vivem nessas cidades ao ritmo desse tempo. A sabedoria seria então, saber se aproveitar dessa vida que o campo dá:

Jack, marujo inglês, tu tens razão

Quando, ancorado em portos como os nossos,

As laranjas com cascas e caroços

Comes com bestial sofreguidão!... ${ }^{253}$

Após esses versos "utilitaristas", este Eu volta-se novamente para si, e, novamente seu pendor artístico aflora, mas não somente pela questão estética, mas para processar uma espécie de milagre da ressuscitação. Também é importante notar que faz uma espécie de poética pessoal, explicando sua técnica de composição:

Todos os tipos mortos ressuscito!

Perpetuam-se assim alguns minutos!

E eu exagero os casos diminutos

Dentro de um véu de lágrimas bendito.

Pinto quadros por letras, por sinais,

\footnotetext{
${ }^{252}$ MACEDO, Helder, op.cit, p. 205.

${ }^{253}$ Ibidem, p. 173.
} 
Tão luminosos como os de Levante,

Nas horas em que a calma é mais queimante,

Na quadra em que o verão aperta mais. ${ }^{254}$

A rigorosa e moderníssima definição do seu método poético como uma construção, através dos sinais específicos da escrita, de um "quadro" ou representação equivalente à percepção visual ${ }^{255}$, prepara a transferência da sua perspectiva do subjetivismo da intrspoecção para a objetividade da observação. Esta deriva é imediatamente cristalizada no rasgo estilístico funcional da transposição metonímica de um estado de espírito ou qualidade subjetiva numa característica do mundo exterior representada:

Como destacam, vivas, certas cores,

Na vida externa cheia de alegrias!

As descrições pormenorizadas que se seguem das vistas, sons e cheiros da alegre "vida externa" resultam, portanto da aplicação consciente de um método poético que visa à representação rigorosa das relações dinâmicas entre o sujeito, o espaço objectivo e o tempo subjecivo. Cesário vai assim "pintar", numa série de quadros verbais, as animadas cenas do cultivo e da exportação de frutas através de uma sistemática justaposição de pormenores concretos e de abstrações, numa complexa interpenetração de imagens que transpõe para as coisas que o discurso poético institui como significantes visuais da vida externa os estados psicológicos por ela provocados. $^{256}$

Os versos seguintes demonstram, através da visão que este Eu tem das coisas, a integração que pretende atingir. Tudo nele desperta uma sensação e toda imagem precede da realidade para ser "pintada". Mesmo quando diz que : "Ah! Ninguém entender que ao meu olhar/ Tudo tem certo espírito secreto!” não está andando nos bosques baudelieranos, e sim que o segredo está exatamente nessa captura, nessa possibilidade desse momento etéreo de

\footnotetext{
${ }^{254}$ VERDE, Cesário, op.cit p. 173

${ }^{255}$ Helder Macedo esclarece, citando Taine: "Nesta passagem Cesário parece trazer uma mais ampla dimensão estrutural às idéias de Taine sobre a função dos sinais ("signers") e dos nomes ("noms") como substitutos ("subistituts") do real na formação das imagens. Após escrever que "um sinal é uma experiência presente que nos sugere a idéia de uma experiência possível" e que os "nomes são uma espécie de sinais", Taine conclui que o "nome por si próprio pode tomar o lugar da imagem que desperta e, por consequiência, da experiência que recorda; faz a sua função e é o seu subistituto" (H. Taine, De l'Intelligence, Vol. I, pp. 25-29)

${ }^{256}$ MACEDO, Helder, op.cit, p. 212
} 
conciliação com o exterior. Veremos, no entanto, nas próprias palavras deste $\mathrm{Eu}$, que sua integração ao povo do campo não passa de uma idéia:

A mim mesmo, que tenho a pretensão

De ter saúde, a mim que adoro a pompa

Das forças, pode ser que me rompa

Uma artéria, e me mine uma lesão! $!^{257}$

Afinal, ele sabe-se de uma cepa distinta, dos ricos, sinônimo neste poema dos que não são da terra. Mas, pode-se pensar também, que não se trata somente na questão biológica, de ser ou não da terra. Pode ser, tão simplesmente a constatação do "cranco enorme", que, afinal, corrói a todos, principalmente àqueles desta época de fins-de-secule, corrompidos todos de alguma maneira pela nova ordem vigente. Por isso, os velhos, de uma outra época, e os fortes, representantes destes homens da terra são os sobreviventes.

Pobre da minha geração exangue

De ricos! Antes, como os abrutados,

Andar com uns sapatos ensebados,

E ter riqueza química no sangue!... ${ }^{258}$

Porque, parece, ou fortes, ou velhacos,

Serão apenas os sobreviventes

E há pessoas sinceras e clementes,

E troncos grossos com seus ramos fracos!

E que fazer, se a geração decai!

Se a seiva genealógica se gasta!

Tudo empobrece! Extingue-se uma casta!

Morre o filho primeiro do que o pai! ${ }^{259}$

\footnotetext{
${ }^{257}$ VERDE, Cesário, op.cit, p. 181.

${ }^{258}$ Ibidem, p. 178.

${ }^{259}$ Ibidem, p. 182.
} 
Esta noção da brevitude e da incoerência da vida, somada ao túmulo da irmã, fazem com que este Eu medite sobre o Incognoscível, que chama de "infinito". Sua reflexão não leva a alívio algum, e sim a substituição da misericórdia religiosa, da fé numa vida eterna, pela imagem da irmã. $\mathrm{O}$ que se trata de uma imagem altamente reflexiva: se a possibilidade da ressuscitação ou do encontro com os mortos não pode ser dada pela religião, pode, como o próprio Eu reconheceu, no rememorar artístico. Se nos poemas anteriores ressaltou-se a questão do fazer artístico como constituição primordial deste Eu, aqui, latente, vemos que se trata também de preencher aquele vazio que, por ventura, reste após se esgotar as inquietações defronte à um mundo em caos, desarmônico:

\section{E quanto a mim, és tu que substituis}

Todo o mistério, toda a santidade

Quando em busca do reino da verdade

Eu ergo os olhos aos céus azuis.

Na última parte do poema, no tempo presente da confecção deste, o Eu depara-se com a morte do irmão. Isto lhe causará profunda perplexidade, pois, a irmã tinha sinais claros de não pertencer àquele campo saudável, mas, como se antecipou, quando este eu usava o pronome "nós", não o utilizava apenas num sentido genérico, mas também, como pode ser compreendido pela primeira parte do poema, no sentido de delimitar aquele "nós" ao circulo familiar. Utilizou-o também quando falava da lida do campo, no que se entende que o irmão também fazia parte. Não é só um lamentar a perda de um ente ou visualizar sua própria morte, pois a perda da irmã fraca e do irmão forte poderia representar uma fraqueza latente, "em seu sangue". Sua morte, ele mesmo a decreta. Trata-se também de lamentar a impossibilidade da arte como resposta para o inexplicável; trata-se do divórcio deste Eu com suas letras, seu âmago constituidor e sua única resposta aos desígnios do mistério. Emblemático que este poema tenha tal nome e seja o último completo: Nós, fechada a cortina deste palco absurdo que é a vida, é a forma que este Eu encontrou de não mais se nomear, não se constituir e não mais tentar se prolongar. Prolongar o quê, parece se questionar este Eu, desconcertado com o mundo e principalmente, consigo mesmo:

E agora, de tal modo a minha vida é dura,

Tenho momentos maus, tão tristes, tão perversos,

Que sinto só desdém pela literatura, 
E até desprezo e esqueço os meus amados versos! $!^{260}$

${ }^{260}$ VERDE, Cesário, op.cit p. 184. 


\section{Conclusão}

Percorrer, um verbo que exatifica a idéia dessa leitura em particular, a obra de Cesário Verde sob o prisma da constituição do Eu, é, como foi apontado nos capítulos, verificar um andar em direção ao desconcerto maior que poderia ocorrer na constituição deste Eu: a possibilidade de uma constituição atemporal, não remedia a temporalidade e mesmo a fragilidade de tal constituição. O ser que este Eu poderia delimitar ou recriar, neste exercício do artístico humano, e conceder, em contraponto a mundanidade deste criador, a eternidade memoralística da escrita, compreende que este subterfúgio, ao fim e ao cabo, não o redime e não diminui o peso daquela mundanidade. Seu lugar o mundo, ou seu fazer seu mundo está perdido no momento que não se mais se contenta ou se alivia neste exercício demiúrgico. A conclusão desta dissertação está espalhada por todo o corpo desta leitura: não há uma unidade conclusiva, assim como não há uma unidade poética na estética cesárica. O que se faz aqui é dar uma unidade às respostas daquelas perguntas inicias, e também justificar a escolha do título. Pode-se argumentar que tal justificativa deveria vir na introdução, mas temeu-se com isso condicionar a leitura para somente tal idéia, do desconcerto, ou da defesa de tal idéia. Se dirá que, ao menos, uma linha de raciocínio crítico foi respeitada, mas, como se viu, o respeito a somente uma linha poderia transformar a leitura em justificativa de uma tese, e não o contrário. Da leitura surgiram as "teses", às vezes contraditórias, porém sempre respeitantes na questão da escrita intimista.

$\mathrm{Na}$ parte que chamamos de Do risível amor de si ao desastre do Outro as características marcantes são a ironia, o deboche, e a irreverência com que certos temas e clichês românticos são tratados. Essa atitude demonstra uma crítica ao convencional, mas demonstra também, à parte o tratamento estilístico, a crise pessoal surgida de certas inquietações deste $e u$ em relação ao outro do poema, primeiramente mulheres impossíveis e posteriormente, um outro que ganha uma identidade, uma função, e transfere essa mesma possibilidade de identidade para este eu. Na parte que chamamos Do amor ao outro ao desastre de si vemos como os motivos cotidianos, o banal e por vezes o vulgar, toma lugar importante para a constituição deste $e u$. Porém, a atitude mais marcante será o olhar que dedica ao outro, o olhar que transfere de si aos personagens deste enredo que constrói em torno das crises. Crise, palavra chave para o entendimento da poética cesárica, também é a palavra chave para o entendimento da linha desta dissertação. Foi baseado na afirmação de 
Joel Serrão de que a poesia de Cesário é “(...) uma poesia de crise, em crise” que se começou a delinear qual seria o elemento principal para a leitura dessa poética. De onde surgiu também o título.

A partir da idéia do desconcerto do mundo, contraponto a idéia de concerto renascentista, notadamente presente na lírica e na épica camoniana, pensou-se no equivalente em relação ao $e u$, já que era a partir, e ao redor deste, que a leitura e o sentido dos poemas foram construídos: “(...) o desconcerto vai aos poucos deixando de ser vago temor, ou mero torneio retórico , mal disfarçado por Camões, para se tornar, também, fato de realidade, a multiforme realidade que volta e meia, quando menos se espera, surge de pernas para o ar, ao menos aos olhos de escritores como Bocage, Gonzaga, Garet, Camilo, Alencar, Antero, Eça, Machado, Cesário, Proust, Pessoa, Cesariny ou Roberto Piva."261

O termo desconcerto porém, por estar ligado de forma intrínseca com o Renascimento levanta dúvidas em relação ao seu uso fora deste contexto. Diria-se, numa resposta curta e inexata, que o desconcerto é aqui lido com os olhos fixos no contraponto ordem-caos, externo-interno, mas sabendo de soslaio que há uma tradição. A licença para a (indevida talvez) apropriação do termo é mais bem dada pelas palavras de Carlos Felipe Moisés:

(...)o desconcerto, antes de ser entronizado como tema "nobre", foco aglutinador de portentosa erudição, sempre foi e continua a ser assunto corrente, de interesse geral, ou seja, fato de realidade.(...) O desconcerto, com efeito, obrigaria o especialista a aceitar o desconforto de um mundo inteiramente novo, ergo desconhecido, reinaugurado a cada gesto, a cada verso.Já a assumida ignorância do amador não vê dificuldade em afinar seu instrumento pelo diapasão da estranheza e do constante recomeço. ${ }^{262}$

Transferindo a idéia do especialista e do amador para a poética cesárica, parece claro que o próprio tratamento estilístico da crise contrapõe tal idéia. Na primeira parte, temos esse desconforto de um eu perante aos ideais impossíveis românticos, a idéia impossível de conciliação do $e u$ consigo mesmo e principalmente, a instauração de uma crise que vai de

\footnotetext{
${ }^{261}$ MOISÉS, Carlos Felipe. O Desconcerto do Mundo: do Renascimento ao Surrealismo. São Paulo: Escrituras Editora, 2001, p.12.

${ }^{262}$ Ibidem, p. 12 e 14.
} 
dentro para fora. Inversamente, esta crise, que se percebe fora, penetra e atordoa este $e u$ que se constituiu exatamente por elementos externos, como a temporalidade e a função. Neste ponto, ele é o amador a ver a estranheza e assumi-la como algo novo, que pode ser assimilada por seus olhos de poeta. Mas, é essa mesma relação que desperta aquela crise interna, causando esse desconcerto não no mundo, já desconcertado, mas no eu.

Como la religión, la poesia parte de la situación humana original - el estar ahí, el sabermos arrojados em esse ahí que es el mundo hostil o indiferente - y del hecho que la hace precária entre todos: su temporalidad, su finitud. Por uma via que, a su manera, es también negativa, el poeta llega al borde del lenguage. Y esse borde se llama silencio, página em blanco. Un silencio que es como um lago, uma superfície lisa y compacta. Dentro, sumergidas, aguardan las palabras. Y hay que descender, ir al fondo, callar, esperar. La esterilidad precede a la inspiración, como el vacío a la plenitud. La palabra poética brota trás eras de sequía. Mas cualquiera que sea su contenido expresso, su concreta significación, la palabra poética afirma la vida de esta vida. Quiero decir: e lacto poético, el poetizar, el decir del poeta - independietemente del contenido particular de esse decir - es um acto que no constituye, originalmente al menos, uma interpretación, sino uma revelación de nuestra condición. ${ }^{263}$

Se for a morte no início um objeto meramente estilístico, um impacto relativizante de vida, no último poema em particular, ela adentra seu mundo, quando na sua carne, entre seus parentes, ela é sentida. Da morte dos poemas iniciais, quase um mundo hostil, um mero brinquedo, passando pela morte impactante de Desastre, acontecida defronte aos seus olhos, mais ainda distante do seu coração e chegando finalmente ao poema Nós, este eu vê a temporalidade constituir-se não somente como um elemento externo, mas como elemento em que se testa como ser finito. Tal finitude leva este eu à crise, ainda que externa, e consequentemente, a querer a harmonia dentro da linguagem, como se os metros e as rimas pudessem organizar o feio, o vulgar, e as analogias colorissem o cinza, o escuro. São elementos externos, e por essa exterioridade estrutural, mas também por encontrar para si uma individualização neste meio, nomeando-se um artista, este eu, temporariamente, concerta-se enquanto criador.

\footnotetext{
${ }^{263}$ PAZ, Octavio. El arco y la lira. In: La casa de la presencia.2. ed. México: Fondo de Cultura Econômica. 2003, p. 157.
} 
Solução inócua, crença desfeita, este $e u$ após pressentir sua própria finitude enquanto ente despoja-se de seu nome, e diz abandonar seus próprios versos que tanto ama. Amor, que começa como um embate, termina com uma espécie de reconciliação deste $e u$ com o fado imperecível: a desordem, o desconcerto, só foram provisoriamente camuflados e só assim podem ser harmonizados, enquanto aparência, enquanto universo poético. E tal desconcerto existe nele e fora dele, considerando aqui, novamente, as palavras de Carlos Felipe Moisés:

A morfologia garante que "des-concerto" deriva de "concerto", é só a negação ou suspensão momentânea do segundo. Mas a narrativa-mãe de todas as narrativas, o livro do Gênesis, sugere o contrário: no início era o Caos, a Ordem veio depois.(A propósito, a ordem teria vindo depois, para banir em definitivo o caos da origem, ou apenas coloca-lo provisoriamente entre parêntesis?) De qualquer modo, é preciso reconhecer que, no caso da narrativa-mãe, o ponto de partida é outro, é o de um Criador, ou Narrador, situado fora - aquém ou além - do universo já criado ou por criar, apto portanto a lhe apreciar totalidade, concertada ou desconcertada. ${ }^{264}$

Ao delimitar o que chama de memória do corpo, fixada no organismo e memória verdadeira, coexistida à consciência, Bergson pensa no acordo entre as duas:

Não é pela firmeza do acordo, pela precisão com que essas duas memórias complementares se inserem uma na outra, que reconhecemos os espíritos "bem equilibrados", isto é, os homens perfeitamente adaptados à vida? O que caracteriza o homem de ação é a prontidão com que convoca em auxílio de uma situação dada todas as lembranças a ela relacionadas; mas é também a barreira insuperável que encontram nele, ao se apresentarem ao limiar da consciência, as lembranças inúteis ou indiferentes. Viver no presente puro, responder a uma excitação através de uma reação imediata que a prolonga, é próprio de um animal inferior: o homem que procede assim é um impulsivo. Mas não está melhor adaptado à ação aquele que vive no passado por mero prazer, e no qual as lembranças emergem à luz da consciência sem proveito para a situação atual: este não é mais um impulsivo, mas um sonhador. Entre esses dois extremos situa-se a favorável disposição de uma memória bastante dócil para seguir com precisão os contornos da situação presente, mas bastante enérgica para resistir a qualquer outro apelo. $\mathrm{O}$ bom senso, ou senso prático, não é na verdade outra coisa. ${ }^{265}$

\footnotetext{
${ }^{264}$ MOISÉS, Carlos Felipe, op.cit, p. 13.

${ }^{265}$ BERGSON,Henri, op.cit., p.179.
} 
Ressaltou-se na primeira parte desta leitura a questão de um eu olhando para si, recordando-se de um outro, constituindo-se pela impossibilidade das relações, prazerosas carnalmente em geral, temos ali o sonhador. Já na segunda parte, o meio excita os sentidos deste $e u$, prolongando-a ainda mais quando a poetiza. Temos aí o impulsivo. Considerando a idéia do bom senso bergsoniano, pode-se afirmar que o eu cesarico é totalmente destituído dessa "qualidade". Mas o que importa ressaltar é que essas atividades memoralisticas, são cernes deste ser e não somente do mundo. São crises que se encontram e se somam. São crises que o $e u$, feito por si de encruzilhada, sente como sendo, ao fim e ao cabo, como a única verdade, a única unidade e o último lugar onde há de se enterrar. Dessa forma, a idéia do desconcerto do eu, é essa tela em branco aonde o eu vai se mirar, se encontrar e se perder. 


\section{Referências bibliográficas}

AMARAL, Henrique Do - A captação do real em Cesário e em Baudelaire, in Vértice, vol. XV, no. 147, Coimbra, Dez. de 1955, pp. 727-732.

AMBRÓSIO, António - Cesário Verde perante a Igreja, in Diário de Notícias, Lisboa, 21 de Dezembro de 1986.

BACHELARD, Gaston. A Poética do Espaço.6 $6^{\circ}$ Edição.Trad. Antonio de Pádua Danesi.São Paulo: Editora Martins Fontes,2003. Título original: La Poétique de L`Espace.

BOM, Laurinda ; AREIAS Laura - Cesário Verde. Uma Proposta de Trabalho [ed.escolar], Lisboa, Livros Horizonte, 1983.

BUESCU, Helena Carvalhão - Dois poetas da evocação: Cesário Verde e António Nobre "Pinceladas a propósito de Cesário Verde, In Colóquio/Letras, respectivamente no. 75 Set. 1983, e no. 93, Set. 1986.

CABRAL, Avelino Soares - Cesário Verde - Propostas de análise, Lisboa, Edições Sebenta, 2005.

CARTER, Janet E.. Cadências tristes. O universo humano na obra Poética de Cesário Verde.Lisboa: Imprensa Nacional - Casa da Moeda, 1989.

COELHO, Jacinto do Prado. A letra e o leitor. $2^{\circ}$ Edição. Lisboa: Moraes Editores, 1977 Problemática da História Literária. $2^{\circ}$ Edição.Lisboa: Edições Atica, 1961.

CORBIN, Alain. O segredo do indivíduo.Trad. Denise Bottmann e Bernardo Joffily. In: PERROT, Michelle(org.).História da Vida Privada 4: Da Revolução Francesa à Primeira 
Guerra.10 ed.reimp.São Paulo: Companhia das Letras, 2006. Título Original: Historie de la vie privée, vol 4: De la Révolution à la Grande Guerre.

DAUT, Ricardo - O Livro de Cesário Verde: Leituras e comparações, Tese de doutoramento, 1999.

DUBY, Georges. A Emergência do Indivíduo.Trad. Maria Lucia Machado. In: DUBY, Georges (Org.). História da Vida Privada, 2: Da Europa feudal à Renascença. 13. ed. São Paulo: Companhia das Letras, 1990.Título Original: Histoire de la vie privée, vol.2: De l'Europe féodale à la Renaissance.

DUBY, Georges (Org.). História da Vida Privada 3: Da Renascença ao Século das Luzes. 13. ed. São Paulo: Companhia das Letras, 1990.Título Original: Histoire de la vie privée, vol 3: De la Renaissance aux Lumières.

ECO, Umberto. A estrutura ausente. Introdução à pesquisa semiológica. Trad. Pérola de Carvalho.São Paulo, Perspectiva, Editora da USP, 1971 (Coleção Estudos). Titulo original: La struttura assente.

História da Feiúra. $1^{\circ}$ Edição. Trad. Eliana Aguiar. Rio de Janeiro: Editora Record, 2007. Título original: Storia della brutezza. Interpretação e Superinterpretação. $3^{\circ}$ Edição. Trad. M.F. São Paulo: Editora Martins Fontes, 2001. Título original: Interpretation and Overinterpretation.

FERNANDES, Annie Gisele. Espaços do ser e do não-ser e a construção do sujeito em Mário de Sá-Carneiro. In: FERNANDES, Annie Gisele; OLIVEIRA, Paulo Motta. Literatura Portuguesa: Aquém-Mar. Campinas: Editora Komedi, 2005.

FERREIRA, Vergílio - Relendo Cesário, in Colóquio/Letras, no. 31, Lisboa, Maio de 1976, pp. 49-58.

FIGUEIREDO, João Pinto - A Vida de Cesário Verde, Lisboa, 2ed. Editorial Presença, 1896. 
FOISIL, Madeleine. A Escritura do Foro Privado. Trad. Hildegard Feist. In: ARIÉS, Philippe; DUBY, Georges (Org.). História da Vida Privada 3: Da Renascença ao Século das Luzes. 13. ed. São Paulo: Companhia das Letras, 1990.Título Original: Histoire de la vie privée, vol 3: De la Renaissance aux Lumières.

FOUCAULT, Michel. O que é um autor?. Trad. António Fernando Cascais e Eduardo Cordeiro. 6. ed. Lisboa: Nova Vega, 2006. Título Original: Qu'est-ce qu'un auteur?

FREUD, Sigmund. Dicionário Filosófico de citações. In: GRATELOUP, Leon-Louis (org.). Trad. Marina Appenzeller. São Paulo: Martins Fontes, 2004.Título original: Dictionaire philosophique de citations.

GOMES, Álvaro Cardoso - A consciência em crise em Cesário Verde, in Língua e Literatura, no. 5, São Paulo, 1976, pp. 55-66.

GOULEMOT, Jean Marie. As práticas literárias ou a publicidade do privado. Trad. Hildegard Feist. In: ARIÉS, Philippe; DUBY, Georges (Org.). História da Vida Privada 3: Da Renascença ao Século das Luzes. 13. ed. São Paulo: Companhia das Letras, 1990.Título Original: Histoire de la vie privée, vol 3: De la Renaissance aux Lumières.

GRATELOUP, Leon- Louis. Dicionário Filosófico de Citações. $1^{\circ}$ Edição. Trad. Marina Appenzeller. São Paulo: Editora Fontes, 2004. Título original: Dictionnaire Philosophique de Citations.

HEGEL, GeorgWilhelm Friedrich. Cursos de Estética I. $2^{\circ}$ Edição.Trad. Marco Aurélio Werle.São Paulo: Edusp - Editora da Universidade de São Paulo,2001. Título original: Vorlesungen über die ästhetik.

HEIDEGGER, Martin. El Ser y el Tiempo. $4^{\circ}$ Edição. Trad. José Gaos. México: Editora Fondo de Cultura Económica,1971. Título original: Sein und Zeit. 
JUNG, Carl Gustav. O eu e o inconsciente. $18^{\circ}$ Edição. Trad. Dora Ferreira da Silva. Petrópolis: Editora Vozes, 2004. Título do Original Alemão: Zwei Schriften Über Analytische Psychologie. Die Beziehungen zwischen den Ich und dem unbewussten.

LOPES, Oscar - Cesário ou do Romantismo ao Modernism, in Vértice, vol. XXVII, no. 284, Coimbra, maio de 1967, pp. 257-265.

LOPES, Rita Sousa. Para uma leitura de Cesário Verde. $1^{\circ}$ Edição.Lisboa: Editorial Presença , 2000.

MACEDO, Helder. Nós: Uma leitura de Cesário Verde. $4^{\circ}$ Edição. Lisboa: Editora Editorial Presença, 1999.

MARTINS, Cabral. Cesário Verde ou a Transformação do Mundo. $1^{\circ}$ Edição. (Coleção Estudos da Cultura Portuguesa). Lisboa: Editorial Comunicação,1988.

MATHIAS, Marcello Duarte. Autobiografias e Diários. In: Colóquios/Letras. JaneiroJunho 1997, número 143/144.

MOISÉS, Carlos Felipe. O Desconcerto do Mundo: do Renascimento ao Surrealismo. São Paulo: Escrituras Editora, 2001 - (Coleção ensaios transversais).

Poesia Completa \& Cartas Escolhidas / Cesário Verde. São Paulo: Editora Cultrix, Editora da Universidade de São Paulo, 1982.

MOISÉS, Massaud. Dicionário de Termos Literários.19. ed. São Paulo: Cultrix, 2000, p. 295.

NIETZSCHE, Friedrich. Humano, demasiado humano.Um Livro para espíritos livres. Trad. Paulo César de Souza. São Paulo: Companhia das letras, 2005. Título original: Menschliches, Allzumenschliches. Ein Buch für freie Geister (1878.1886). 
OLIVEIRA, Luís Amaro de - Cesário Verde (Novos subsídios para o estudo da sua personalidade), Coimbra, 1944.

PASCHOALIN, Maria Aparecida - A Poesia de Cesário Verde: Lirismo e Realidade Social, dissertação de mestrado pela USP, 1980.

PAZ, Octavio. O Desconhecido de si mesmo - Fernando Pessoa. Trad. Sebastião Uchoa Leite. In: Signos em Rotações. 3. ed. São Paulo: Editora Perspectiva, 2003.

PEREIRA, José Carlos Seabra - Decadentismo e Simbolismo na Poesia portuguesa, Coimbra, 1975.

RÉGIO, José - Sobre o realismo de Cesário, in Estrada Larga, I, Porto, 1958, pp. 329395.

ROCHA, Andrée Crabbé - A presença do real na poesia de Cesário Verde, in Estrada Larga.

_“Cesário Verde, poeta barroco?”, in Colóquio/Letras, no. 1, Lisboa, 1971, pp. 31-33.

ROCHA, Clara. Máscaras de Narciso: Estudos sobre a literatura autobiográfica em Portugal. Coimbra: Almedina. 1992.

ROUGEMONT, Denis. História do Amor no Ocidente. Trad. Paulo Brandi ; Ethel Brandi Cachapuz. 2. ed. São Paulo: Ediouro, 2003.

SACRAMENTO, Mário - Lírica e Dialéctica em Cesário verde, Ensaios de Domingo, Coimbra, 1959, pp. 93-137.

SENA, Jorge - A linguagem de Cesário Verde, Estrada Larga I.

SERRÃO, Joel - Cesário Verde - Interpretação, poesias dispersas e cartas, Lisboa, 1957. 
Temas Oitocentistas - I: Para a história de Portugal no século passado. Lisboa: Portugália Editora,1962. Funchal,Portugal: Livros Horizonte, 1980.

Temas Oitocentistas - II: Para a história de Portugal no século passado. Lisboa: Portugália Editora,1962.

SIMÕES, João Gaspar - Eça de Queiroz, mestre de Cesário Verde e precursor da poesia moderna, in O Primeiro de Janeiro, Porto, 14-3-1945.

TORRES, Alexandre Pinheiro - A Paleta de Cesário Verde, Lisboa, 2003.

VERDE, Cesário. Obra completa de Cesário Verde. SERRÃO, Joel (org.). 8 ed. Lisboa: Livros Horizontes, 2003. 